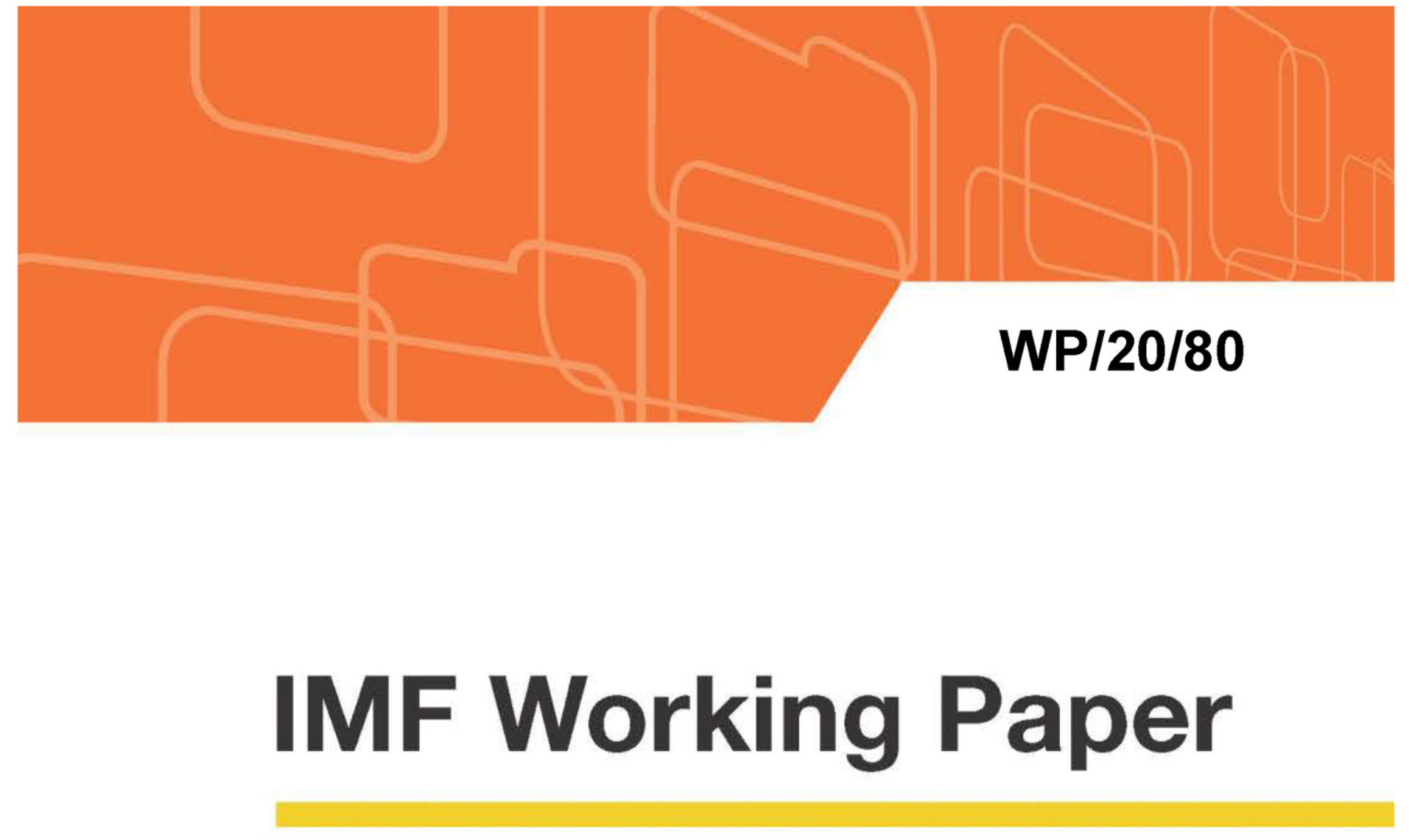

\title{
Estimated Policy Rules for Capital Controls
}

by Gurnain Kaur Pasricha

IMF Working Papers describe research in progress by the author(s) and are published to elicit comments and to encourage debate. The views expressed in IMF Working Papers are those of the author(s) and do not necessarily represent the views of the IMF, its Executive Board, or IMF management. 


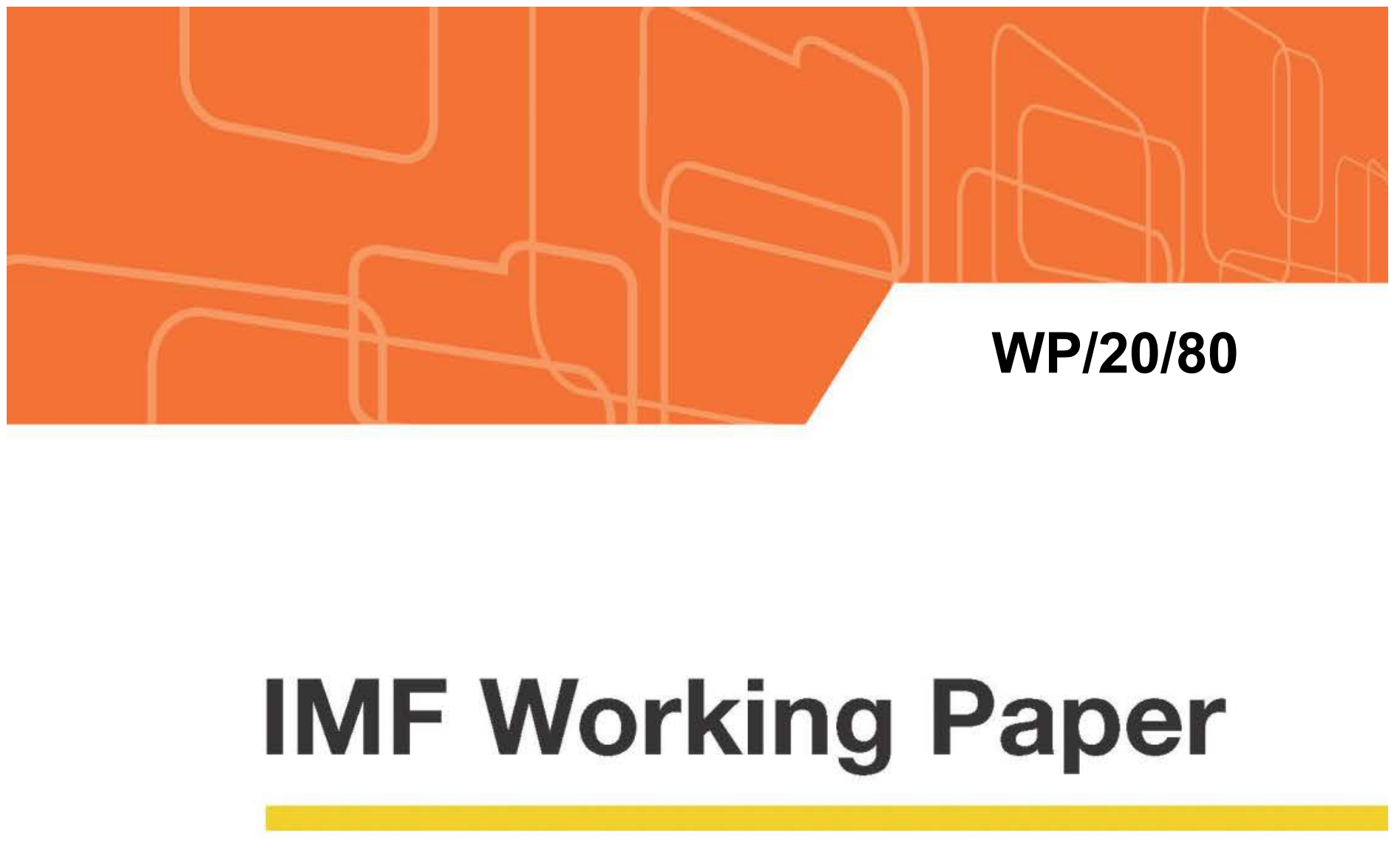

\section{Estimated Policy Rules for Capital Controls}

by Gurnain Kaur Pasricha

IMF Working Papers describe research in progress by the author(s) and are published to elicit comments and to encourage debate. The views expressed in IMF Working Papers are those of the author(s) and do not necessarily represent the views of the IMF, its Executive Board, or IMF management. 


\title{
IMF Working Paper
}

Monetary and Capital Markets Department

Estimated Policy Rules for Capital Controls

Prepared by Gurnain Kaur Pasricha ${ }^{1}$

Authorized for distribution by Gaston Gelos

June 2020

IMF Working Papers describe research in progress by the author(s) and are published to elicit comments and to encourage debate. The views expressed in IMF Working Papers are those of the author(s) and do not necessarily represent the views of the IMF, its Executive Board, or IMF management.

Disclaimer: This document was prepared before COVID-19 became a global pandemic and resulted in unprecedented economic strains. It, therefore, does not reflect the implications of these developments and related policy priorities. We direct you to the IMF Covid-19 page that includes staff recommendations with regard to the COVID-19 global outbreak.

\begin{abstract}
This paper borrows the tradition of estimating policy reaction functions from monetary policy literature to ask whether capital controls respond to macroprudential or mercantilist motivations. I explore this question using a novel, weekly dataset on capital control actions in 21 emerging economies from 2001 to 2015. I introduce a new proxy for mercantilist motivations: the weighted appreciation of an emerging-market currency against its top five trade competitors. This proxy Granger causes future net initiations of non-tariff barriers in most countries. Emerging markets systematically respond to both mercantilist and macroprudential motivations. Policymakers respond to trade competitiveness concerns by using both instruments - inflow tightening and outflow easing. They use only inflow tightening in response to macroprudential concerns. Policy is acyclical to foreign debt; however, high levels of this debt reduces countercyclicality to mercantilist concerns. Higher exchange rate pass-through to export prices, and having an inflation targeting regime with non-freely floating exchange rates, increase responsiveness to mercantilist concerns.
\end{abstract}

\section{JEL Classification Numbers: F3, F4, F5, G0, G1}

Keywords: capital controls, macroprudential policy, mercantilist motivations, capital flows, emerging markets, policy rules

Author’s E-Mail Address: gpasricha@imf.org

\footnotetext{
${ }^{1}$ The work for this paper was supported by the Visiting Central Bank Research Fellowship of the BIS. My thanks to J. Aizenman, T. Bayoumi, J. Bengui, S. Bhalla, A. Chari, J. Chapman, P. Conway, A. Fernandez, L. Gambacorta, G. Gelos, R. Goyal, A. Korinek, M. Kaufman, P. Khera, R. McCauley, V. Rai, R. Sousa, S. Sgherri, J. Yoo, staff from Banco de Mexico, conference participants at several conferences and seminars for helpful comments and suggestions. Min Jae Kim and Raheeb Dastagir provided excellent research support.
} 


\section{INTRODUCTION}

Capital controls are restrictions on cross-border trade in assets. The recent global financial crisis has reignited the debate on systematic use of capital controls to manage domestic economic and financial cycles. Certain capital controls have increasingly been viewed as part of a broader policy toolkit for maintaining financial stability, i.e., as ex-ante tools to prevent buildup of systemic risk by limiting the growth of credit (BIS-FSB-IMF, 2011; G20, 2011; Ostry et al., 2011; and Ostry et al., 2012). ${ }^{2}$

This new approach is backed by a growing theoretical literature that views capital controls as optimal ex-ante policies that address the consequences of pecuniary externalities in residents' borrowing decisions (Mendoza, 2002; Korinek, 2010; Korinek and Sandri, 2016; Bianchi, 2011; Uribe, 2007). In this framework, residents face a collateral constraint that depends on the real exchange rate. Individual agents take the real exchange rate (and the value of the collateral) as given when taking their borrowing decisions, but in aggregate, the real exchange rate depends on the borrowing decisions of the individuals. This feedback loop leads to excessive foreign borrowing in good times and increases the probability of a crisis. Capital controls that limit real exchange rate appreciation in cyclical upturns also limit excessive borrowing and are therefore viewed as macroprudential tools.

While much of the recent literature and the policy discussion has focused on the macroprudential objective of capital controls, there is another potential objective of capital control policy - the mercantilist objective. ${ }^{3}$ Here, the objective is to promote exports by manipulating the terms of trade or preventing foreign control of strategic industries (Bernanke, 2015; Bhalla, 2012; Costinot et al., 2014; Heathcote and Perri, 2016; Dooley et al., 2014; and Acharya and Bengui, 2018). Proponents of this view argue that attempts to prevent the exchange rate from appreciating are in fact motivated by the objective of gaining trade advantage over export competitors. Furthermore, the imposition of capital controls by one emerging-market economy (EME) during upturns in the global financial cycle can deflect capital flows to other emerging markets and can lead to a beggar-thy-neighbour currency war. ${ }^{4}$

Are capital controls macroprudential or mercantilist? This question is not merely of academic interest but has important implications for operationalizing the new consensus on limited,

\footnotetext{
${ }^{2}$ Note that the IMF's Institutional View (IMF, 2012) emphasizes that capital controls "are part of the toolkit and their use is appropriate under certain conditions, but they should not substitute for warranted macroeconomic adjustment. When capital flows contribute to systemic financial risks, CFMs in combination with macro-prudential measures more broadly can help to safeguard financial stability, although their costs need also to be taken into account."

${ }^{3}$ The term "new mercantilism" was used in the context of the reserves accumulation debate before the global financial crisis, in the paper by Dooley et al. (2003), and has since been used to describe the strategy of managing the exchange rate through systematic calibration of capital controls on inflows as well. For empirical literature assessing mercantilist motive in reserves accumulation, see Aizenman and Lee (2007), Ghosh et al. (2012) and references therein. For a survey of the theoretical literature on the mercantilist motive in reserves accumulation, also see Durdu et al. (2009).

${ }^{4}$ For evidence on the spillover effects of capital controls, see Pasricha et al. (2018), Forbes et al. (2016) and references therein.
} 
disciplined use of capital controls. As Carney (2019) notes, "There are two major challenges in operationalizing capital flow management measures. The first is proving intent so as not to provoke retaliation. The second is that they can panic investors and make matters worse." However, there is surprisingly little empirical evidence on the intent with which these tools have been used by emerging markets. A recent paper by Fernández et al. (2015b) finds that capital controls do not vary over the business cycle. On the mercantilism objective, there is only indirect evidence that certain types of inflow controls benefit the largest exporting firms (Alfaro et al., 2017).

The paper asks: With which objectives - macroprudential or mercantilist - have policymakers in emerging economies used capital controls? It takes a policy reaction function approach, clearly delineating the different motivations, and the trade-offs therein. There is some recent literature that has tried to predict capital controls (Fernández et al., 2015b; Fratzscher, 2014; Forbes et al., 2015; Aizenman and Pasricha, 2013). However, these papers focus on specific variables to which policy responds, not on identifying mutually exclusive motivations that these variables represent. ${ }^{5}$ For example, the papers assess whether policy reacts to net capital inflows (NKI) and find that it does. But the motivation behind that NKI response could be macroprudential or mercantilist. This paper estimates a descriptive, empirical policy reaction function to explore how policy reacts to these competing objectives.

The idea of asking how policy should or does react to competing objectives is well established in economics. Monetary economics has a long tradition of estimating monetary policy rules (e.g., Taylor, 1993). The premise is that well-designed policy rules can allow policymakers to overcome time-inconsistency problems with monetary policy, gain credibility and therefore make policy more effective. Policy rules can also allow policymakers to communicate policy more effectively and enhance accountability of the monetary authority. In a similar vein, recent literature has explored the time-inconsistency of domestic macroprudential policy under commitment (Bianchi and Mendoza, 2016). They find that the optimal time-consistent policy is a complex function of time and state-dependent variables, and that well-optimized financial Taylor rules, while less effective than optimal policy, can improve welfare over no-intervention.

This paper estimates a descriptive reaction function, without claiming that such reaction functions reflect optimal rules. Even without an assessment of optimality, this exercise is important as it contributes to improving the transparency of policy. ${ }^{6}$ Transparent policy

\footnotetext{
${ }^{5}$ Fratzscher (2014) and Fernandez et al. (2015b) use data on levels of capital controls, rather than on policy actions. Forbes et al. (2015) and Aizenman and Pasricha (2013) use datasets on capital control policy actions at higher frequencies. However, the Forbes study uses data only for the post-global financial crisis period, from 2009-2011, and the focus of the paper is on estimating effects of capital controls rather than on disentangling the different motivations for using capital controls. Aizenman and Pasricha (2013) focus on outflow controls only, and on whether the possible loss of fiscal revenue from repression constrained EMEs' use of outflow controls to manage the net capital inflow pressures.

${ }^{6}$ The Taylor rule is prescriptive-it recommends how policy-makers should react. However, when he proposed it in 1993, one of Taylor's contributions was to show that his rule was also descriptive - that the optimal rule that theory predicted turned out also to describe well the behavior of the Federal Reserve Board in the 1980s and early ' 90 s.
} 
reaction functions can help attract capital inflows and prevent destabilizing outflows when the controls are used, by constraining the ability to expropriate past investments (Ljungqvist and Sargent, 2004). ${ }^{7}$ They can also strengthen the accountability of the macroprudential authority, assuage concerns about the spillovers of such policy, and prevent retaliation by other countries by establishing intent.

To disentangle mercantilist from macroprudential motivations, the paper introduces a novel proxy for mercantilist concerns: the appreciation of an EME's currency against its top five trade competitors. EMEs' use of capital controls to prevent REER appreciation or appreciation against the U.S. dollar could in theory, reflect the desire to prevent an increase in collateral value (as envisaged in recent literature) or the desire to promote exports or protect import-competing industries. ${ }^{8}$ Both these measures therefore suffer from the shortcoming that they could reflect both macroprudential and mercantilist motivations (as most EME agents are able to borrow only in hard currencies of countries which are also main export destinations and import suppliers for these EMEs). To get cleaner identification, I propose a novel proxy for mercantilist concerns that measures the appreciation of an EME's currency against its top five trade competitors. As these competitors are emerging or developing countries, in whose currencies the EMEs do not borrow, the movements of the EME currencies against the currencies of these countries do not reflect macroprudential concerns but capture only mercantilist concerns. This proxy is positively correlated with, and Granger causes initiations of non-tariff barriers in most countries, further bolstering its usefulness as a mercantilism proxy. I also construct a version of the proxy that is orthogonal to appreciation against the US dollar.

A final contribution of the paper is that it uses a detailed weekly dataset on capital controls policy that directly measures policy actions by 21 major emerging market economies over the period 2001-2015. I extend the Pasricha et al. (2018) dataset by three years, 2013-15, and use the announcement dates of the policy actions, rather than the effective dates used in Pasricha et al. (2018). The use of data on policy actions also closely parallels the monetary literature on modeling central bank policy rate.

The paper has several new and interesting results on the use of capital controls in emerging markets. The results provide evidence that capital controls policy in emerging economies has been systematic, and that it has responded to both macroprudential and mercantilist motivations. Moreover, I find that the choice of instruments is systematic: policymakers respond to mercantilist concerns by using both instruments - inflow tightening and outflow easing. However, they use only inflow tightening in response to macroprudential concerns. This paper provides evidence that the macroprudential motivation existed in the use of capital controls policy, even before these controls were generally acknowledged (after the global financial crisis) as valid tools of the macroprudential policy toolkit. Yet, the results in

\footnotetext{
${ }^{7}$ In Chapter 15, Ljungqvist and Sargent (2004) show that under discretion, the government has an incentive to tax all past investment at time 0 and then set the capital tax to zero for future dates.

${ }^{8}$ In practice, however, the exchange rate and financial cycles are not perfectly synchronized, and the objectives of containing systemic risk from capital flows and mitigating REER appreciation can involve trade-offs as well. This issue is explored in Appendix A.
} 
this paper underline that the concerns about a currency war are also justified — capital controls have also been systematically used to preserve competitive advantage in trade.

Further, I find that policy is not countercyclical to the specific macroprudential concerns related to external or foreign currency borrowing. Rather, policy appears acyclical to these variables. However, foreign currency debt matters in a non-linear way - countries with very high foreign currency debt have a different reaction function: countries in these states respond less countercyclically to mercantilist motivations and somewhat countercyclically to macroprudential motivations, as measured by changes in foreign currency debt.

Finally, I find that the mercantilism objective is stronger in countries with higher exchange rate pass-through (ERPT) to export prices, and in inflation targeting countries that do not have a freely floating exchange rate. Higher ERPT to export prices means that exporters do not change the prices in their domestic currency much in response to appreciation of their currency. ${ }^{9}$ As a result, the customers of these countries face much of the cost of the currency appreciation, potentially making the exports of these countries more sensitive to appreciation. I find that countries with high export price ERPT react more strongly to mercantilist motivations, particularly when the exchange rate pressures against competitors are strong. Inflation targeting countries are limited in using monetary policy to manage exchange rate, and may rely more on capital controls for this purpose.

The rest of the paper is organized as follows. Section II reviews the literature on the motivations for capital controls. Section III reviews describes the new the mercantilism proxy. Section IV describes the data on capital control policy actions. Section V describes the empirical strategy and the data on other macro financial variables. Section VI describes the results and assesses the fit of the baseline models. Section VII evaluates robustness of the main results. Section VIII concludes.

\section{Literature Survey: The Motivations For CAPital Controls}

The literature identifies two main motivations for using inflow side capital controls: mercantilist and macroprudential. ${ }^{10}$ In this section, I survey the empirical and theoretical literature on each of these motivations.

\footnotetext{
${ }^{9}$ Note that countries with higher dollar currency pricing will likely have lower exchange rate pass through to export prices than those with producer currency pricing. In this paper, I only use the relative pass-through, i.e., dividing countries by whether they have higher than median pass-through or not. The actual level of passthrough is not used to derive the results.

${ }^{10}$ A third key motivation for the use of capital controls is macroeconomic stabilization, i.e., to prevent overheating of the economy in periods of excessive inflows and to maintain monetary policy independence. Schmitt-Grohe and Uribe (2016b) shows that the need to capital controls can arise due to a fixed exchange rate regime, which constrains monetary policy. They show that capital controls imposed with a macroeconomic motivation are counter-cyclical to the business cycle. While I control for this motivation in the empirical analysis, it is not discussed in detail as the estimated coefficients are not significant.
} 


\section{A. Macroprudential Motivation}

Macroprudential policy is defined by an objective - that of addressing systemic risks in the financial sector to ensure a stable provision of financial services to the real economy over time (BIS-FSB-IMF, 2011). Under this policy framework, capital controls could be considered tools of macroprudential policy if they specifically target the systemic risks stemming from external finance, particularly those that could be addressed using other (non-residency-based) prudential tools. To do so, these tools would be used countercyclically to systemic risk, as is done with other macroprudential policy tools.

A large recent literature has explored the role of capital controls as macroprudential tools, in models where agents face pecuniary externalities arising from occasionally binding collateral constraints (Bianchi, 2011; Jeanne and Korinek, 2010; Benigno et al., 2011; Korinek, 2016; Schmitt-Grohé and Uribe, 2016a). As the probability that the collateral constraint will bind increases with the level of debt, some models recommend that the capital controls be set to positive values once debt levels are high, or have crossed a threshold (Bianchi, 2011; Korinek, 2011). Agenor and Jia (2015) show that a simple countercyclical capital controls rule, in which the tax on foreign borrowing is countercyclical to the changes in foreign borrowing by banks, performs well relative to the Ramsey optimal policy. ${ }^{11}$

Assessing whether capital controls have been used as macroprudential tools would therefore necessitate the assessment of whether these tools were countercyclical to measures of systemic risk. Measures of systemic risk may include, but are not limited to, credit-to-GDP gap, levels or growth of foreign credit - in particular, foreign currency or short-term creditand asset price booms. ${ }^{12}$ Following the literature, therefore, I use countercyclicality to various measures of systemic risk as the measure of macroprudential objective, and propose a new proxy for mercantilist objective, discussed in the next section.

\section{B. Mercantilist Motivation}

Mercantilist motivation can be understood as the strategy to promote export-led development by keeping the exchange rate undervalued, through a combination of capital controls and reserves accumulation (Dooley et al., 2003, 2014). A large empirical literature has tested the macroeconomic versus prudential motivations for foreign exchange reserves accumulation, a policy complementary to or a substitute for capital controls (Aizenman and Lee, 2007; Choi and Taylor, 2017; Ghosh et al., 2012; Cheung and Qian, 2009; Jeanne and Ranciere, 2006). In this literature, export growth rates and exchange rate undervaluation relative to

\footnotetext{
${ }^{11}$ The countercyclicality of the optimal policy depends on the model assumptions. Schmitt-Grohe and Uribe (2016a) show that the Ramsey optimal policy in some models is in fact pro-cyclical, where the tax rate should be lowered in booms and increased during recessions. This result could be sensitive to the nature and time series properties of shocks, as well as the assumption that the planner sets the tax level high enough such that the shadow value of collateral to individual is zero at all times. Further, Devereaux and Yu (2019) show that the direction of optimal capital controls is different under fixed and flexible exchange rate regimes. With flexible exchange rates, policy makers impose inflow taxes immediately at the onset of a crisis, whereas under pegged exchange rates, they impose capital inflow subsidies.

${ }^{12}$ Greenfield FDI is assumed not to create externalities, and therefore does not warrant restrictions (Korinek, 2016).
} 
fundamental purchasing power parity value are used as proxies of mercantilist motivation, with higher levels of reserves associated with greater undervaluation and greater export growth. This works because these regression specifications focus on explaining cross-country differences in levels of reserves. If the mercantilist strategy is successful, one would expect countries that ended up accumulating larger reserves hoardings to have seen higher export growth and undervalued exchange rates. Yet this does not directly translate into a policy strategy: should countries intervene more (through reserves accumulation or capital controls) when export growth is high or when it is lagging?

An alternative would be to use measures of exchange rate appreciation (nominal or real). However, as discussed above, the recent theoretical literature on macroprudential capital controls views the target of macroprudential policy as encompassing targeting the REER, or even the nominal exchange rate. It views exchange rate appreciation as the channel that facilitates over-borrowing, especially foreign currency borrowing. These models imply that simply finding that policy responds to exchange rate doesn't imply policy is mercantilist (or macroprudential). ${ }^{13}$ This suggests a need to explore other proxies of mercantilist

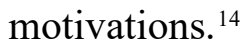

\section{A New Proxy for Mercantilist Motivations}

In order to isolate the mercantilist motivation in exchange rate management, I propose a new proxy for mercantilist motivations. This proxy is the weighted appreciation of the exchange rate against a country's top five trade competitors. When the exchange rate is appreciating against trade competitors, the EME can be interpreted as losing competitiveness in the world market. The reason this proxy works is that the trade competitors of most EMEs in our sample are other EMEs, and most EMEs do not borrow in the currencies of their trade competitors. ${ }^{15}$ In the terminology of the recent theoretical literature on pecuniary externalities, the collateral constraint is not denominated in the currencies of the trade competitors, rather in the base currencies (U.S. dollar or euro). Therefore, while resisting appreciation against the base currency (U.S. dollar or euro) per se could capture either mercantilist or macroprudential concerns, resisting appreciation against trade competitors should capture only the mercantilist motivation. To illustrate, an appreciation against the U.S. dollar would not be problematic from mercantilist perspective if the competitors' currencies are appreciating faster, while it could still be problematic from a macroprudential perspective.

\footnotetext{
${ }^{13}$ Note that in these models, the mercantilist motivation for capital controls is not explored. The only benefit of mitigating real exchange rate appreciation is mitigating external credit cycles.

${ }^{14}$ Another variable that could reflect mercantilist motivation is suggested by Costinot, Lorenzoni and Werning (2014). In a two-country model, they find that from a mercantilist perspective, the optimal capital controls policy is countercyclical. In their model, a country growing faster than its trading partner has incentives to promote domestic savings by taxing capital inflows or subsidizing capital outflows, and vice versa. However, the relative growth rate may not capture the mercantilist motivations for small open economies like most emerging markets, which do not have the ability to manipulate world interest rate through their own capital controls.

${ }^{15}$ An exception is Korea, for which since 2006, four trade competitors out of top 5 have been advanced economies whose currencies are an international reserve currency. I test the robustness of the results by excluding Korea, in section VII.
} 
To identify trade competitors, I use the merchandise trade correlation index, developed by the United Nations Conference on Trade and Development (UNCTAD). ${ }^{16}$ The trade correlation index is a simple correlation coefficient between economy A's and economy B's trade specialization index and can take a value from -1 to 1 . A positive value indicates that the economies are competitors in the global market since both countries are net exporters of the same set of products. A negative value suggests that the economies do not specialize in the production or consumption of the same goods and are therefore natural trading partners. ${ }^{17}$ The specialization index removes bias of high export values because of significant re-export activities; thus, it is suitable to identify real producers rather than traders. ${ }^{18}$

For each EME in our sample, I identify five countries with which it has the highest trade correlation index in each year. Next, I compute the weighted exchange rate appreciation of the EME's currency against the five trade competitors, at quarterly and annual horizons, and in real and nominal terms. That is, I compute the following proxies:

$$
\begin{aligned}
& W A P P R Q_{i t}=400 *\left[\sum_{j=1}^{5} w_{i j t}\left\{\left(x_{i t}-L^{13} x_{i t}\right)-\left(x_{j t}-L^{13} x_{j t}\right)\right\}\right] \\
& W A P P R Y_{i t}=100 *\left[\sum_{j=1}^{5} w_{i j t}\left\{\left(x_{i t}-L^{52} x_{i t}\right)-\left(x_{j t}-L^{52} x_{j t}\right)\right\}\right]
\end{aligned}
$$

And the two real proxies are defined as:

$$
\begin{aligned}
& W \boldsymbol{R A P P R Q} Q_{i t}=100 *\left[\sum_{j=1}^{5} w_{i j t}\left\{4\left(x_{i t}-L^{13} x_{i t}\right)-4\left(x_{j t}-L^{13} x_{j t}\right)+\left(\pi_{i t-1}-\pi_{j t-1}\right)\right\}\right] \\
& W \boldsymbol{R} A P P R Y_{i t}=100 *\left[\sum_{j=1}^{5} w_{i j t}\left\{\left(x_{i t}-L^{52} x_{i t}\right)-\left(x_{j t}-L^{52} x_{j t}\right)+\left(\pi_{i t-1}-\pi_{j t-1}\right)\right\}\right]
\end{aligned}
$$

where $x_{i t}$ and $x_{j t}$ are respectively the natural logs of the nominal exchange rate against the U.S. dollar for countries $i$ and $j$ as of the end of week $t$ (measured in USD per domestic currency unit), $L$ is the lag operator and $\pi_{i t}$ is the year-over-year (52-week) change in log of consumer price index (CPI) as of week $t, w_{i j t}$ is the weight assigned to competitor $j$ and is measured by the trade correlation index between country $i$ and country $j$ in week $t$ (and is the same for all weeks in a calendar year). The set of trade competitors $(j)$ included in the calculation of the index varies over time but is reasonably stable over five-year periods in the sample.

\footnotetext{
16 The UNCTAD trade correlation index was downloaded in November 2016, when it was available on an annual basis from 1995 to 2012. I use the 2012 competitor countries for 2013-2015. I look for trade competitors in a sample of 75 countries, to drop potential competitors that are too small. A list of trade competitors for each of the emerging markets in sample in 2012 is in Appendix Table C3.

${ }^{17}$ This index doesn't take into account the extent to which each country competes with its competitors in third party markets. For example, if India and China export the same products, but to different countries, they are not necessarily competing with each other and the yuan exchange rate would not matter as much for India. A real exchange rate index that also takes this competition in third markets into account is computed in IDB (2016).

${ }^{18}$ A large and growing literature questions the ability of standard REER indices to capture changes in trade competitiveness, given the transformation of global trade because of emergence of global value chains. The existing REER indices do not control for trade in intermediate inputs and impute the entire value of the export to the exporting country, even if the value added in that country is very small. Therefore, these indices do not capture well the true competitive pressures (Patel et al., 2017). The UNCATAD measure controls for the reexporting activities and therefore allows us to better identify trade competitors than we would by using weights of standard REER indices.
} 
The nominal proxies $W A P P R Q_{i t}$ and $W A P P R Y_{i t}$ measure the weighted nominal appreciation of a country's currency over the previous quarter (13 weeks) and over the previous year (52 weeks), respectively. The real proxies are analogously interpreted. All proxies express the appreciation at annual rates and as percentages.

Finally, I compute a country-specific proxy, which uses for each country the mercantilism proxy (from equations 1-4 above) that is most important for that country, i.e., most highly correlated with capital control changes. I use this in the baseline models, and generally refer to this as the "Mercantilism Proxy (country-specific)," unless otherwise specified. That is, I compute the country-specific correlation coefficient (over the full sample period) between (weighted, non-FDI) net inflow tightening measures $\left(W H N T I_{i t}\right)$, defined in the next section, and each of the four proxies defined above. Then that country's mercantilism proxy is the series with the highest correlation coefficient. I call this proxy $W A P P R_{i t}$, with the understanding that it uses a different series for each country. I also construct a version of this proxy that is orthogonal to appreciation against US dollar, as described in section VI.A.

The mercantilism proxy achieves the objective of identifying mercantilist motivations separately from macroprudential motivations. While the REER is positively correlated for most countries with domestic bank credit to GDP gap and growth for most countries in sample, the mercantilism proxy is uncorrelated or negatively correlated with these variables (Figure 1). In robustness checks, I further validate the proxy as a measure of mercantilist motivations by testing its relationship with non-tariff barriers to trade.

\section{Figure 1: Mercantilism Proxy is Uncorrelated or Negatively Correlated with} Bank Credit to GDP Gap and Growth

(a) Correlations with Bank Credit to GDP Gap

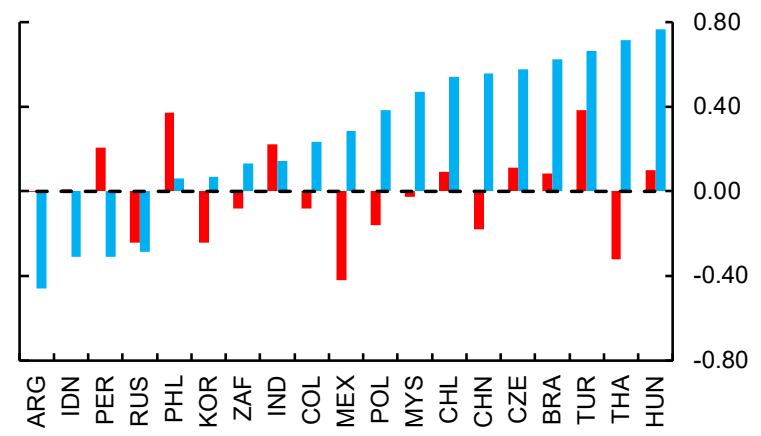

- Mercantilism Proxy (Country-Specific) (b) Correlations with Bank Credit to GDP Growth

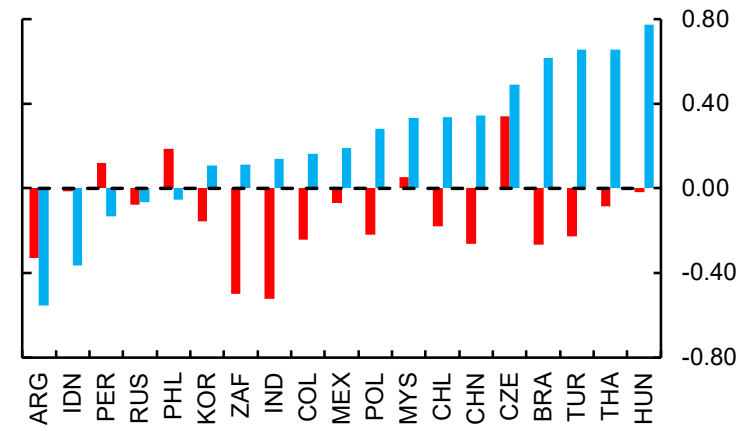

- REER

Source: Author's calculations.

Note: Bank credit to GDP growth is the year over year change in domestic bank credit to the private sector as percentage of GDP. REER is the real effective exchange rate. Mercantilism proxy is as defined in the text. 


\section{Measuring Capital Control ACtions}

I assess the motivations for capital controls by using a detailed dataset on actual policy actions, at a weekly frequency. I update the Pasricha et al. (2018) indices on capital control policy actions for 21 EMEs through 2015. This dataset uses a narrative approach-reading the text of the policy changes or descriptions of such changes in other sources - and converting them into numerical measures that capture the direction of policy. An advantage of this dataset compared to other high-frequency datasets on capital control actions in the literature, is that it is granular: policy announcements often contain changes of multiple regulatory instruments. These announcements are split along six dimensions to yield a granular database of policy changes or policy actions. ${ }^{19}$ The identified policy actions are then aggregated to compute measures of policy direction.

Most of the paper focuses on explaining (weighted, non-FDI) net inflow tightening measures $\left(W H N T I_{i t}\right)$, as much of the policy debate and theoretical literature on macroprudential capital controls focuses on inflow restrictions. This measure is computed as the number of (weighted, non-FDI) inflow tightening minus easing actions per week. However, as both inflow tightening and outflow easing can be used to respond to competitiveness pressures, I also assess the motivations for (weighted, non-FDI) net NKI restricting measures, which is the sum of (weighted, non-FDI) net inflow tightening and (weighted, non-FDI) net outflow easing measures. ${ }^{20}$

It is important to note that are three main differences in the aggregation methods between the data used in this paper and the Pasricha et al. (2018) dataset. First, in this paper, I use the announcement dates of the changes, rather than their effective dates. Second, I drop changes that were pre-announced by more than 60 days, as changes that have more than a 60 -day implementation lag are likely to be more structural in nature, rather than imposed for macroeconomic and macroprudential management. Third, in this paper, I include changes that potentially affect both inflows and outflows (e.g., currency-based measures) on both the inflow and outflow sides. That is, these changes are counted twice.

The resulting data shows a high degree of variation in policy, even in countries with extensive and long-standing capital controls. Figure 2 plots the cumulated versions of weighted net inflow tightening actions and weighted net outflow easing measures for China and India, two countries with extensive and long-standing capital controls. The figure shows that on the whole, both countries have taken more liberalization actions than tightening actions since 2001 on both inflow and outflow sides, but it also shows periods of tightening of inflow restrictions (2004-05, 2007-08 and again 2010-11 for China) as well as periods of tightening of outflow restrictions (2015, also for China).

\footnotetext{
${ }^{19}$ See Appendix B for a description of the dataset used in this paper, including the differences in aggregation methods in this paper and the Pasricha et al. (2018) dataset. A detailed description of the Pasricha et al. (2018) dataset and the dataset itself are available online: http:/www.nber.org/papers/w20822/. Please also see the appendix posted there for a comparison of weighted and unweighted datasets.

${ }^{20}$ Net outflow easings are computed as number of outflow easing actions less outflow tightening actions per week.
} 


\section{Figure 2: Pasricha et al. (2018) Indices of Capital Controls Liberalization}

(a) China

Daily data

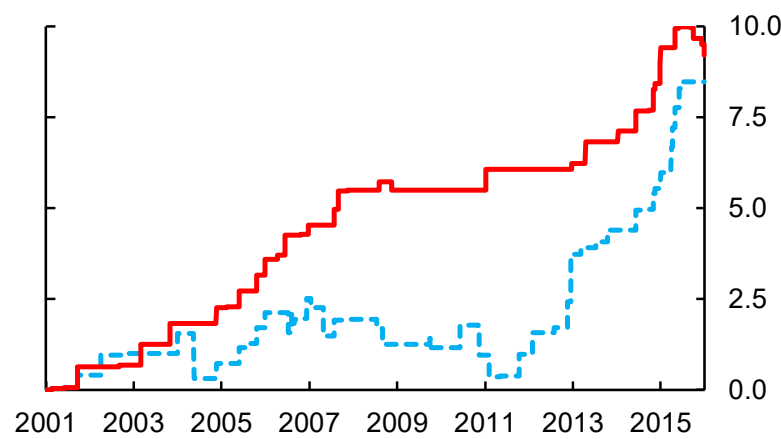

(b) India

Daily data

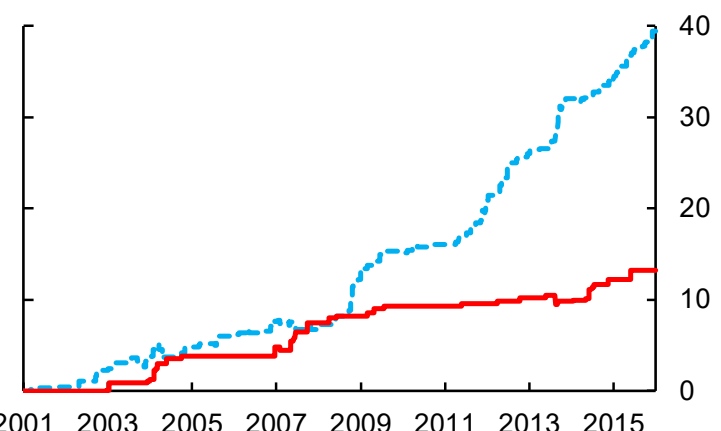

Source: Author's calculations.

Note: Figures include policy actions related to FDI and exclude those that were implemented more than 60 days after announcement. Actions that affect both inflows and outflows are included in both red and blue lines.

Last observation: 31 December 2015

Figure 3: Baseline Models Include the 11 Most Active Countries Total Number of Policy Actions: 1 Jan 2001 - 31 Dec 2015

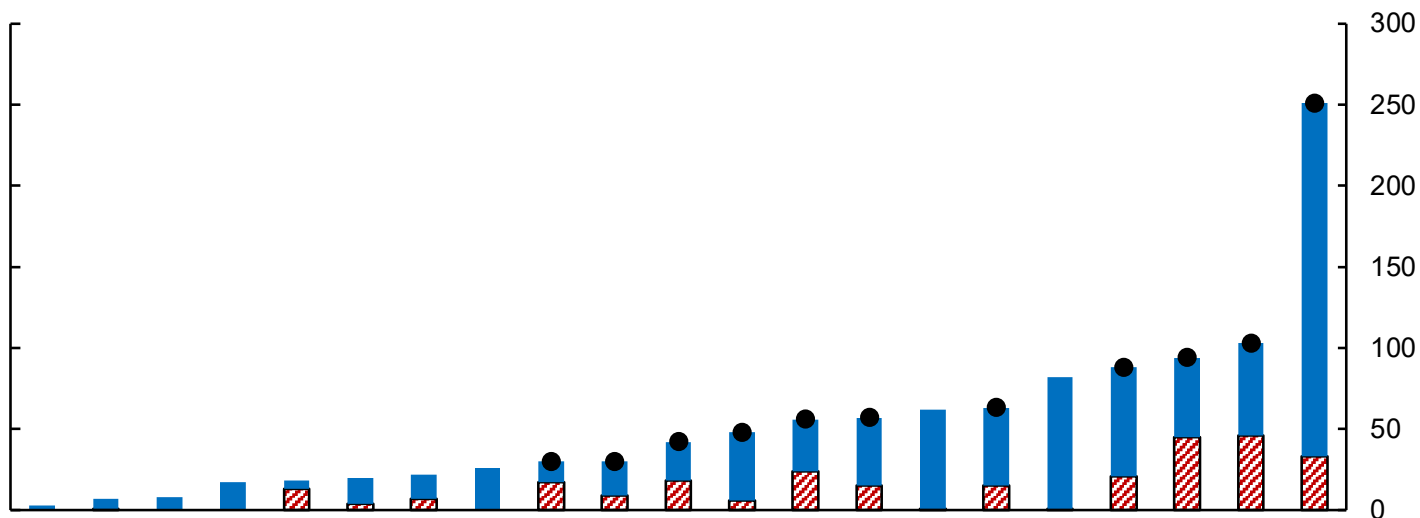

EGY CZE MEXMAR IDN POL HUN CHL COL RUS TUR PHL BRA KOR ZAF THA MYSCHN PER ARG IND

$\square$ No. of Tightening Actions $\quad$ No. of Easing Actions $\quad \bullet$ Countries in Sample

Source: Author's calculations.

Note: Black dots mark countries included in the baseline models. These are countries wiht at least 30 actions in sample and at least one inflow tightening action. Red shaed bard denote the total number of tightening actions (on inflows and outflows) by the country and blue bars are the total number of easing actions (on inflows and outflows). This chart plots unweighted policy actions, includes FDI-related actions, and counts actions not specific to inflows and outflows only once.

Last observation: 31 December 2015 
Not all emerging markets were equally active in changing capital controls policies (Figure 3 ). In the baseline models for net inflow tightening actions, I use the 11 most active countries, i.e., those that had at least 30 policy actions in the 15 -year period, with at least one inflow tightening. ${ }^{21}$ For baseline models for net NKI restricting actions, I use an additional 2 countries - South Africa and Malaysia - who have at least 30 actions in sample, but no inflow tightening. This choice of sample is based on the nature of the exercise. Although very interesting, the question we are exploring here is not why some countries rely more on capital controls as policy tools and others not at all - the answer may depend on the institutional arrangements and policy preferences in these countries as well as their international agreements (e.g., European Union or OECD). The question we are exploring here is whether the actions of countries that do use capital controls or currency-based measures are predictable based on certain macroeconomic and macro-prudential variables.

\section{ECONOMETRIC METHOdOLOGY AND DATA}

\section{A. Econometric Methodology}

The baseline model is a panel ordered logit model of the form:

$$
\operatorname{Pr}\left(y_{i t}=s_{k} \mid w_{i t-1}\right)=f\left\{X_{i t-1}^{M P} \beta^{M P}+X_{i t-1}^{F X} \beta^{F X}+\mathrm{X}_{t}^{G} \beta^{G}+\mathrm{X}_{i t-1}^{O} \beta^{O}\right\},
$$

where $y_{i t}$ is the number of policy actions by country $i$ in week $t, \operatorname{Pr}\left(y_{i t}=s_{k} \mid w_{i t-1}\right)$ is the conditional probability that country $i$ takes $s_{k}$ actions in week $t . \mathrm{X}_{i t-1}^{M P}$ and $\mathrm{X}_{i t-1}^{F X}$ are the variables representing macroprudential (MP) and mercantilist (FX) motivations, respectively. $\mathrm{X}_{t}^{G}$ controls for the global variables and $\mathrm{X}_{i t-1}^{O}$ controls for the other domestic variables.

In the baseline models, $y_{i t}$ refers to either (weighted, non-FDI) net inflow tightening actions or (weighted, non-FDI) net NKI restricting measures. The weighting scheme for capital controls makes the number of policy actions per week a continuous variable, yet there is little difference in the strength of policy actions that are measured as, for example, 0.24 vs. 0.28. In the baseline models, I consolidate the number of ordered categories, the weighted capital controls variable into five, as follows:

$$
y_{i t}^{o}=\left\{\begin{array}{ccc}
-1 & \text { if } & y_{i t}<-0.5 \\
-0.5 & \text { if } & -0.5 \leq y_{i t} \leq 0 \\
0 & \text { if } & y_{i t}=0 \\
0.5 & \text { if } & 0<y_{i t} \leq 0.5 \\
1 & \text { if } & y_{i t} \geq 0.5
\end{array}\right.
$$

The baseline models estimate equation (5) for $y_{i t}^{o}$. This transformation does not affect the main conclusions, as shown in the robustness checks, but makes the estimations substantially faster. The models are estimated using random effects, but the results are robust to adding country-specific dummies. ${ }^{22}$ The reported coefficients are proportional odds ratios-values more than 1 indicate countercyclical use of policies.

\footnotetext{
${ }^{21}$ Full sample results are reported in the robustness checks section.

${ }^{22}$ Results available on request.
} 


\section{B. Macro-Financial Data}

In the baseline model, I use one of the five mercantilism proxies described in section III to capture mercantilist motivations. For the macroprudential motivation, I use the domestic bank credit-to-GDP gap. This variable is defined as the deviation from a backward-looking HP-filtered trend of the ratio of domestic bank credit to private non-financial sector to GDP. The data on bank credit is from the Bank for International Settlements (BIS). The reason for choosing this variable as the main macroprudential variable is that it is viewed as a key indicator of systemic risk in the Basel III agreement, and comprises on average over 75 percent of total credit in the active countries over the sample period. ${ }^{23}$ The recent early warning literature on financial crises - for example, Jorda, Schularick and Taylor (2012) also highlights the importance of bank credit as a measure of systemic risk.

To capture push factors $\left(\mathrm{X}_{\mathrm{t}}^{\mathrm{G}}\right)$, the baseline model includes the Chicago Board of Options Exchange Volatility Index (VIX).

Other domestic variables $\left(\mathrm{X}_{\mathrm{it}-1}^{\mathrm{O}}\right)$ include domestic variables that may capture the additional motivations for capital controls (for example, macroeconomic management), as well as variables that capture other domestic policies that are substitutes for or complements to capital control changes. To capture macroeconomic management motivation, I include the $\mathrm{CPI}$ inflation rate in all specifications. This variable captures the overheating pressures in the economy. I also include a crisis dummy, which equals 1 for the global financial crisis (2008: Q4) and for three domestic crises in Argentina (2001: Q1-2003: Q4), Russia (2001: Q12001: Q4) and Turkey (2001: Q1-2004: Q1).

In terms of other domestic policies, reserves accumulation is the oft-used policy to manage the exchange rate, alongside or as substitute to capital controls, and is included in all specifications. To capture monetary policy stance, I use a dummy variable that takes the value 1 if the policy rate is increased in the quarter, 0 if there is no change in policy rate between the current and the previous quarter, and -1 if monetary policy is eased in the current quarter. As an increase in interest rates can make capital inflows more attractive, policymakers concerned about the value of the currency may simultaneously tighten inflow controls to curb the resulting appreciation pressures. A dummy for fiscal stance is similarly defined as taking the value +1 if the general government structural balance (as $\%$ of potential output) increased (reflecting tightening of fiscal policy), -1 if the fiscal stance eased, and 0 otherwise.

To the extent that the domestic policies are substitutes or complements for capital controls, we may expect them to be driven by mercantilist and macroprudential motivations. To test this, I ran fixed effects regressions with each of these policies as dependent variables and the

\footnotetext{
${ }^{23}$ Basel III recommends using the broadest measure of credit possible. BIS makes available data on total credit gap, which includes credit from external sector. However, the time series on this variable starts late in the sample (after 2005 or even 2008) for many EMEs, and is therefore not used in the baseline. The average value of bank credit in total credit reported in the text is the average between 2001-2015 of the ratio of bank credit to private non-financial sector/GDP to total credit to private non-financial sector. The data is from BIS long series on total credit and the average is for Argentina, Brazil, China, Colombia, India, Korea, Russia, Thailand, and Turkey.
} 
mercantilist and macroprudential proxies as explanatory variables. ${ }^{24}$ The results are in Table 1 and show that for reserves accumulation, mercantilist proxies have significant explanatory power, but for other domestic policies (fiscal and monetary policies), neither of these variables have a significant linear relationship. Therefore, in the regressions explaining capital controls, I use the residuals from regression explaining reserves accumulation, to control for that part of reserves accumulation that may be driven by factors uncorrelated with our mercantilism and macroprudential proxies, but that may also drive capital controls, for example, sudden stop risk, financial globalization, ideology of the government in power. ${ }^{25}$ In later sections, I explore the role of some of these factors individually.

Finally, as in Hamilton and Jorda (2002), other domestic variables $\left(\mathrm{X}_{\mathrm{it}-1}^{\mathrm{O}}\right)$ also include an indicator variable that takes the value +1 if the previous policy action (whenever it was) was a tightening and -1 if the previous policy action was an easing. ${ }^{26}$ This variable captures the cycles in capital controls policy.

A note on the frequency of the variables is in order. Exchange rates (and other financial variables used in the second stage) are available at a weekly frequency. However, many of the macro variables are available at a quarterly or lower frequency. These are interpolated to weekly frequency using linear interpolation. An alternative would have been to use the last available value, but that could mean using observations that are no longer relevant for policy decisions. Further, policymaking is a forward-looking activity. The literature on assessing motivations for changes in monetary policy suggests that the results using only lagged variables to explain policy may be biased if policy-makers anticipate future evolution of variables and act on that information: policy-makers may not only change capital controls in response to past changes in economic variables, but also respond to their expectations of future evolution of these (Ramey, 2016). The literature on Taylor Rules addresses this by using Fed's Greenbook forecasts (Monokroussous, 2011 and others). However, such forecasts made by EME policymakers are not available. The interpolations assume that policymakers had information about the evolution of the economy that is not reflected in the previous quarter's data, and that their forecasts are accurate on average. ${ }^{27}$

The data are collected from IMF BOPS, IMF WDI and GEM, UNCTAD, BIS macrofinancial database, Haver and national sources. A full list of variable definitions and sources is in Appendix C.

\footnotetext{
24 The results of the paper are robust to adding additional control variables in these regressions, specifically the other control variables included in the baseline specifications. Results available on request.

${ }^{25}$ Durdu et al. (2009) find that financial globalization and sudden stop risk can explain precautionary demand for foreign exchange reserves. Mendoza and Rojas (2017) point to liability dollarization as a motivation for precautionary demand for reserves.

${ }^{26}$ As the dataset for capital controls starts in 2001, and some countries do not have the first change in sample until later, this variable is set to 0 for values before the first change.

${ }^{27}$ As a robustness check, I repeat the analysis using quarterly data, for which most variables do not need to be interpolated. The results on macroprudential objectives are robust to using lower frequency data. For the mercantilist objectives, the results depend on the dependant variable. For net inflow tightenings, the estimated coefficients for mercantilism proxies are smaller and not significant, but for net NKI restricting measures, the mercantilist proxies are significant using quarterly data as well. Note that the quarterly specification wipes out all intra-quarter variation in exchange rates, and would be expected to result in smaller estimated coefficients.
} 
Table 1: Reserves Accumulation is Partly Driven by Mercantilist Concerns

\begin{tabular}{lccc}
\hline & \multicolumn{3}{c}{ Dependent Variables: } \\
\cline { 2 - 4 } & Fiscal Policy Stance & Monetary Policy Stance & $\Delta$ Reserves/GDP (\%) \\
\hline Mercantilism Proxy (Country-Specific) & $(1)$ & $(2)$ & $(3)$ \\
& 0.02 & -0.04 & $0.21^{* * *}$ \\
Bank Credit-GDP gap (\%) & $(0.04)$ & $(0.03)$ & $(0.07)$ \\
& -0.06 & -0.01 & 0.06 \\
Constant & $(0.07)$ & $(0.02)$ & $(0.07)$ \\
& $-0.36^{* * *}$ & $-0.82^{* * *}$ & $0.57^{* * *}$ \\
Observations & $(0.03)$ & $(0.01)$ & $(0.03)$ \\
R-squared & 10,127 & 10,127 & 10,127 \\
Number of Countries & 0.00 & 0.01 & 0.05 \\
Country Fixed Effects & 13 & 13 & 13 \\
\hline
\end{tabular}

Source: Author's calculations.

Note: All domestic control variables are one-week lagged. All continuous domestic variables are standardized but centered at 0 , i.e., the variables are divided by their standard deviation but not demeaned. Monetary policy stance and fiscal policy stance are variables that take the value +1 if monetary policy is tightened in the previous week (or structural balance improves), -1 for expansionary policies and 0 otherwise. Robust standard errors in parenthesis. ${ }^{* * *} p<0.01,{ }^{* *} p<0.05,{ }^{*} p<0.10$

\section{Model Evaluation}

I evaluate the predictive ability of the baseline model and alternative models using a standard criterion: the area under receiver operating characteristic curve (AUROC). The receiver operating characteristic (ROC) curve evaluates the binary classification ability of a model and has recently been used in early warning literature (Schularick and Taylor, 2012).

Let $\widehat{y *}$ be the linear prediction of the latent variable from a binary logit model (i.e., one with a $0 / 1$ dependent variable). Let predicted outcome be 1 whenever $\widehat{y *}$ crosses a threshold c. That is, the predicted outcome $=\mathrm{I}(\widehat{\mathrm{y} *}-\mathrm{c}>0)$, where $\mathrm{I}($.$) is the indicator function. Then, for$ a given c, one can compute the true positive rate TP(c) (i.e., the percentage of " 1 " observations that are correctly predicted to be "1") and the false positive rate, FP(c) (i.e., the percentage of 0 observations that are incorrectly predicted to be 1$)$. The ROC plots the true positive rate, TP(c), against the false positive rate, $\mathrm{FP}(\mathrm{c})$, for all possible thresholds $\mathrm{c}$ on the real line. The plot is a unit square, as both $\mathrm{TP}(\mathrm{c})$ and $\mathrm{FP}(\mathrm{c})$ vary from 0 to 1 . Any point in the upper left triangle of the square (formed above a 45-degree line from the left corner of the square) has a higher true positive rate than a false positive rate. Therefore, an informative model is one where the ROC curve lies above the 45-degree line, that is, $\mathrm{TP}(\mathrm{c})>\mathrm{FP}(\mathrm{c})$ for all thresholds $\mathrm{c}$ and the model always makes better predictions than the null of a coin toss. The closer the ROC curve is to the top left corner of the square, the better the model. The area under the ROC curve is greater than 0.5 for models with predictive ability.

The ROC curve assesses binary classifier, but the ordered logit model allows for multiple outcomes (five in this paper). Therefore, I compute five logit models, each with dichotomous dependent variable, to evaluate the baseline model in the first stage. The first model estimates a panel logit model, assessing the probability of the most negative outcome $\left(y_{i t}^{o}=-1\right)$ against 
all others. The second model predicts a binary indicator that equals 1 when $y_{i t}^{o}=-0.5$ and 0 otherwise, and so on. I therefore assess whether the model is able to predict better than a coin-toss for each of the five outcomes.

\section{EMPIRICAL RESULTS}

Capital controls policy in emerging markets is systematic and responds to both mercantilist and macroprudential motivations. Moreover, as expected, mercantilist motivations predict inflow controls only when the exchange rate is appreciating - depreciation of exchange rate against trade competitors does not increase the likelihood of easing of inflow controls. On the other hand, inflow controls are fully countercyclical to domestic bank credit to private nonfinancial sector - they are tightened during credit booms and eased during busts. However, inflow controls could be better targeted to sources of systemic risk from capital flows - these controls do not systematically respond to various measures of foreign credit or its growth. However, there is one sense in which countries do change their behavior in response to foreign credit booms - countries with very high foreign currency debt respond less countercyclically to mercantilist concerns. Inflow controls also respond more to mercantilist motivations in countries that have inflation targeting monetary policy frameworks but do not have freely floating exchange rates.

EMEs use both inflow tightening and outflow easing to respond to mercantilist concerns. However, they use only inflow tightening to respond to macroprudential concerns - net NKI restricting measures do not respond to macroprudential concerns. The response of net NKI restricting measures is stronger in countries with relatively high exchange rate pass-through to export prices, i.e., those whose exports stand to suffer more because of currency appreciation.

\section{A. Baseline Results: Mercantilist and Macroprudential Motivations in use of Inflow Tightening Policies}

Inflow controls in emerging markets have systematically responded to both mercantilist and macroprudential motivations. Table 2 presents the results of the baseline model explaining (weighted, non-FDI) net inflow tightening actions. The reported coefficients are proportional odds ratios. A one-standard-deviation increase in the country-specific mercantilism proxy, other things being equal, increases the odds of taking a strong net inflow tightening measure by 21 percent, compared with the alternatives (taking a small net inflow tightening measure, doing nothing or net easing of inflow controls). The results for other mercantilism proxies are similar-a one-standard-deviation nominal appreciation against trade competitors over the previous quarter increases the odds of taking a net inflow tightening measure by $18 \%$, compared with the alternatives. The estimated coefficients for mercantilism proxies are significant at 5\% level of significance.

To further test the identification of mercantilist motivation, in column (6) of Table 2, I use the country-specific mercantilism proxy orthogonal to the appreciation against U.S. dollar. To do this, I use a fixed effects panel regression on the country-specific mercantilism proxy 
with the 13-week appreciation against U.S. dollar and constant as explanatory variables. ${ }^{28}$ I use the residuals from this regression as the mercantilism proxy in Table 2 column (6). This is a challenging specification for mercantilist proxy, as USD appreciation may partly capture mercantilist concerns as well. The results are nevertheless largely unchanged -the mercantilism proxy (now orthogonal to USD appreciation) is significant and has nearly the same magnitude as the baseline results.

On the macroprudential side, a one-standard-deviation increase in bank credit to GDP gap increases the odds of a net inflow tightening by about $24 \%$ relative to the odds of the alternatives, other things being equal. The estimated coefficients for the bank-credit-to-GDP gap are also significant at $1 \%$ levels in all specifications.

Like monetary policy, capital controls policy changes also come in cycles - a net inflow tightening increases the odds that the next action will be a net tightening as well - the odds ratio increases by about $30 \%$. Net tightening of capital controls also comes with improvements in general government structural balances. Monetary policy tightening reduces the odds of net inflow tightening, once previous policy actions and reserves accumulation are controlled for. VIX is not significantly associated with the probability of net inflow tightening measures, but inflow tightening (easing) measures have lower (higher) odds of being used during crisis periods.

A more intuitive way to interpret the coefficients is to compute the average marginal effectthe average change in probability of each outcome for a change in each explanatory variable. These are shown in Figure 4 below, for mercantilist and macroprudential proxies. The responses are as expected. Greater appreciation against trade competitors significantly increases the probability of a net tightening of inflow controls. This appreciation also reduces the probability of net easing of inflow controls, although this impact is not significantly different from zero. An increase in bank credit to GDP gap, on the other hand, significantly increases the probability of net tightening of inflow controls, and significantly reduces the probability of net easing of inflow controls. While the actual size of the average marginal effects may appear small, the unconditional probability of a net tightening action of 0.5 in a given week is $0.84 \%$ and that of a net tightening action equal to 1 is only $0.71 \%$ among the active countries in sample. Further, the average marginal effects are averaged over all observations - as we will see below, the marginal effects are around 10 times larger for inflation targeting (IT) and non-freely floating (non-FF) regimes.

\footnotetext{
${ }^{28}$ The estimated coefficient appreciation against USD is 0.51 , which is significant at $1 \%$ level. The number of countries in the equation is 13 and the R-squared is 0.25 . While this analysis is done for the panel, there will be differences between countries. For example, for Korea, the same first-stage regression has as more than twice as high R-squared, at 0.52 and the estimated coefficient is also higher, at 0.77 . Full results available on request.
} 


\section{Table 2: Baseline: Inflow Controls Respond to both Mercantilist and Macroprudential Concerns}

\begin{tabular}{|c|c|c|c|c|c|c|}
\hline & \multicolumn{6}{|c|}{$\begin{array}{l}\text { Dependent Variable: Weighted Net Inflow Tightenings } \\
\qquad \text { (non-FDI) }\end{array}$} \\
\hline & (1) & (2) & (3) & (4) & (5) & (6) \\
\hline Mercantilism Proxy (Country-Specific) & $1.21^{* *}$ & & & & & \\
\hline Mercantilism Proxy (Nominal, 13-wk appr, \%) & & $1.18^{* *}$ & & & & \\
\hline Mercantilism Proxy (Real, 13-wk appr, \%) & & & $1.19^{\star *}$ & & & \\
\hline Mercantilism Proxy (Nominal, yoy appr, \%) & & & & $1.22^{* *}$ & & \\
\hline Mercantilism Proxy (Real, yoy appr, \%) & & & & & $1.22^{* * *}$ & \\
\hline $\begin{array}{l}\text { Mercantilism Proxy (Orthogonal to USD } \\
\text { appreciation) }\end{array}$ & & & & & & $1.18^{* *}$ \\
\hline Bank Credit-GDP gap (\%) & $1.24^{\star \star \star}$ & $1.24^{* * *}$ & $1.25^{\star \star *}$ & $1.23^{* * *}$ & $1.24^{\star * *}$ & $1.24^{* * *}$ \\
\hline Previous policy action (T, E) & $1.37^{\star * \star}$ & $1.37^{\star \star *}$ & $1.37^{\star * *}$ & $1.37^{\star \star *}$ & $1.37^{* * *}$ & $1.36^{* * *}$ \\
\hline Fiscal Stance & 1.11 & 1.11 & 1.12 & 1.12 & $1.12^{*}$ & 1.11 \\
\hline Monetary Stance & $0.91^{*}$ & $0.91^{*}$ & $0.91^{* *}$ & $0.90^{*}$ & $0.90^{* *}$ & $0.90^{*}$ \\
\hline$\Delta$ Reserves/GDP (\%, residuals) & $1.32^{\star \star *}$ & $1.32^{* \star *}$ & $1.32^{* * *}$ & $1.31^{* * *}$ & $1.31^{* * *}$ & $1.37^{* * *}$ \\
\hline Inflation & 0.94 & 0.93 & $0.91^{*}$ & 0.97 & 0.93 & 0.95 \\
\hline VIX & 0.99 & 0.99 & 0.99 & 0.99 & 0.99 & 0.99 \\
\hline Crisis Dummy & 0.62 & 0.59 & 0.57 & 0.62 & 0.57 & $0.54^{*}$ \\
\hline Observations & 8,558 & 8,558 & 8,558 & 8,558 & 8,558 & 8,550 \\
\hline Number of Countries & 11 & 11 & 11 & 11 & 11 & 11 \\
\hline Pseudo-Log Likelihood & -1836 & -1837 & -1837 & -1836 & -1835 & -1832 \\
\hline Chi-Squared (All coefficients $=0$ ) & 667.8 & 866.6 & 1260 & 217.9 & 360.8 & 135.7 \\
\hline P-value (Chi-Squared) & 0 & 0 & 0 & 0 & 0 & 0 \\
\hline
\end{tabular}

Source: Author's calculations.

Notes: Reported values are proportional odds ratios. Sample period is 2001w1-2015w52. All domestic control variables are one-week lagged. All continuous domestic variables are standardized but centered at 0 , i.e., the variables are divided by their standard deviation but not demeaned. Monetary policy stance and fiscal policy stance are variables that take the value +1 if monetary policy is tightened in the previous week (or structural balance improves), -1 for expansionary policies and 0 otherwise. $\triangle$ Reserves/GDP are residuals from regressions in Table 1. Robust standard errors used. ${ }^{* *} p<0.01,{ }^{* *} p<0.05,{ }^{*} p<0.10$

Our interest is not only in the predictive power of individual coefficients, but in the ability of the model to predict policy, or the goodness of fit of the model. I formally assess the goodness of fit using AUROC, but it is also instructive to look at the actual versus predicted values from the model. Figure 5 plots the actual policy actions versus the predicted values of the latent variable from the baseline model, for four major economies: India, China, Brazil, and Turkey. The figure shows that the latent variables co-move remarkably well with actual inflow policy actions, unlike predictions from the VIX-only model (which are the same for all countries). 
Figure 4: Average Marginal Effects: Baseline Model for Net Inflow Tightening

(a) Mercantilism Proxy

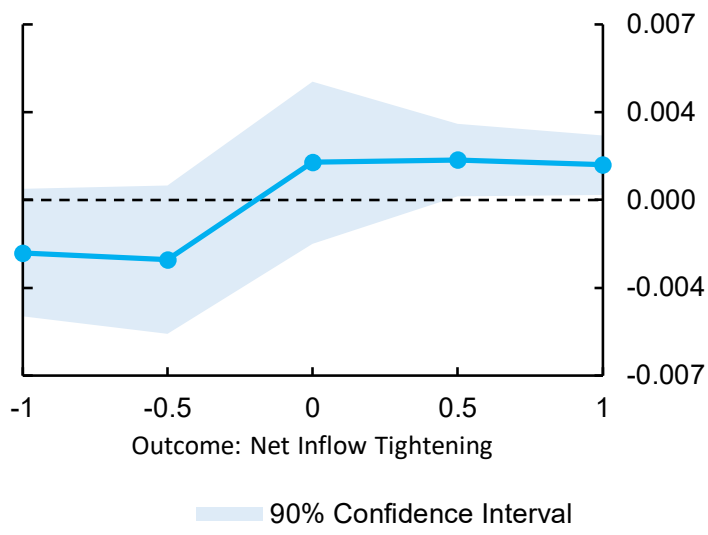

(b) Macroprudential Proxy

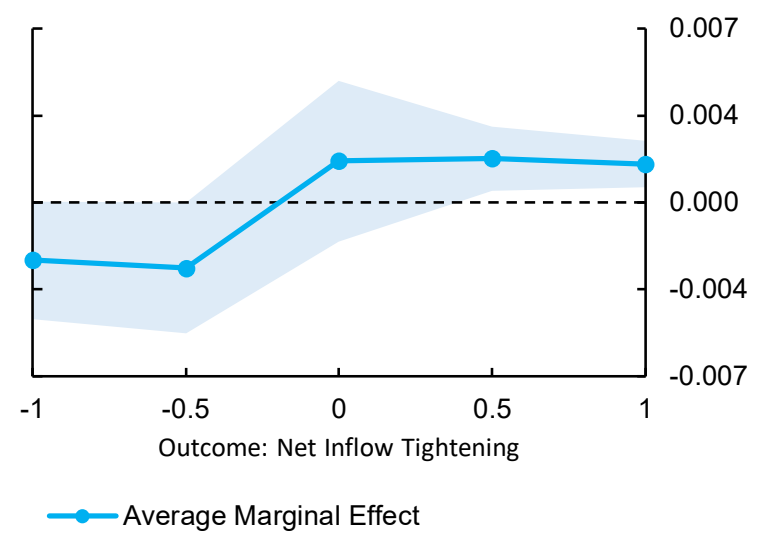

Source: Author's calculations.

Note: The figure computes the average marginal effects for the baseline model with the country-specific mercantilism proxy.

Figure 5: Predicted Latent Variable has a high Degree of Co-Movement with Actual Net Inflow Tightening Actions

(a) Brazil: Actual vs. Predicted

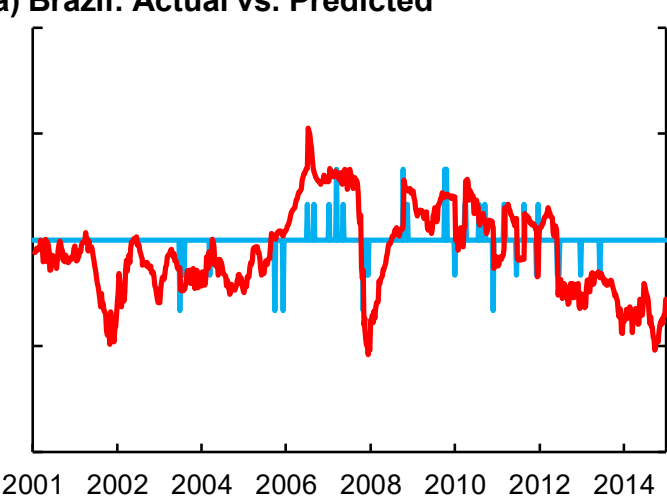

(c) India: Actual vs. Predicted

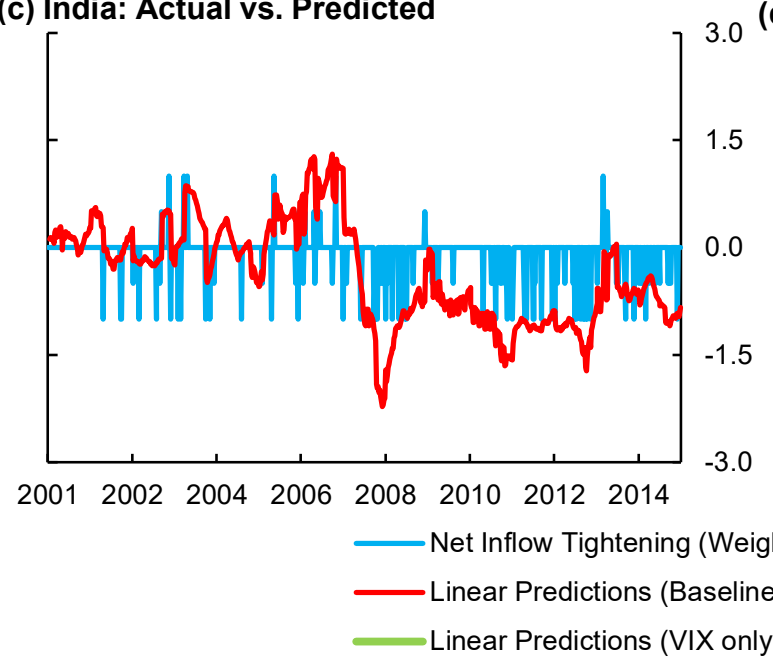

Source: Author's Calculations. (b) China: Actual vs. Predicted

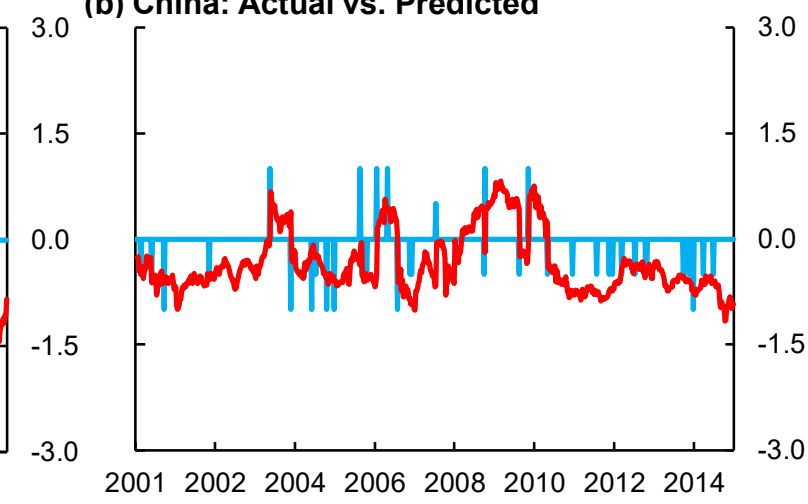

(d) Turkey: Actual vs. Predicted

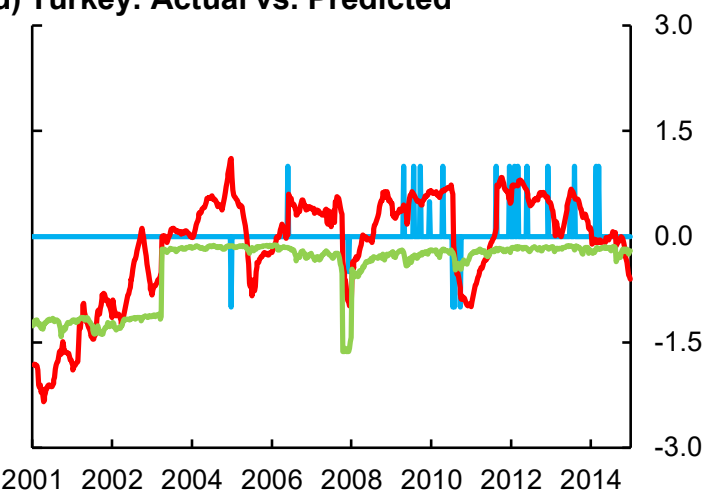

20012002200420062008201020122014 
Table 3: Comparing Models Predicting Inflow Controls-AUROC

\begin{tabular}{|c|c|c|c|c|c|c|c|}
\hline & $\mathrm{N}$ & AUROC & Std. Err. & & f. Interval] & $x^{2}$ & $p$-value \\
\hline \multicolumn{8}{|c|}{ Ordered (Weighted, non-FDI) Net Inflow Tightening = -1 } \\
\hline Baseline & 8558 & 0.688 & 0.03 & 0.63 & 0.74 & & \\
\hline VIX-only & 8558 & 0.541 & 0.03 & 0.48 & 0.61 & 25.7 & 0 \\
\hline FX-only & 8558 & 0.677 & 0.03 & 0.62 & 0.73 & 1.94 & 0.16 \\
\hline MP-only & 8558 & 0.678 & 0.03 & 0.62 & 0.73 & 2.75 & 0.1 \\
\hline \multicolumn{8}{|c|}{ Ordered (Weighted, non-FDI) Net Inflow Tightening = -0.5 } \\
\hline Baseline & 8558 & 0.633 & 0.03 & 0.58 & 0.68 & & \\
\hline VIX-only & 8558 & 0.527 & 0.03 & 0.48 & 0.58 & 8.7 & 0 \\
\hline FX-only & 8558 & 0.607 & 0.02 & 0.56 & 0.66 & 7.81 & 0.01 \\
\hline MP-only & 8558 & 0.632 & 0.03 & 0.58 & 0.68 & 0.01 & 0.92 \\
\hline \multicolumn{8}{|c|}{ Ordered (Weighted, non-FDI) Net Inflow Tightening = 0} \\
\hline Baseline & 8558 & 0.54 & 0.02 & 0.51 & 0.57 & & \\
\hline VIX-only & 8558 & 0.488 & 0.02 & 0.46 & 0.52 & 8.41 & 0 \\
\hline FX-only & 8558 & 0.546 & 0.02 & 0.52 & 0.58 & 2.81 & 0.09 \\
\hline MP-only & 8558 & 0.536 & 0.02 & 0.51 & 0.57 & 0.48 & 0.49 \\
\hline \multicolumn{8}{|c|}{ Ordered (Weighted, non-FDI) Net Inflow Tightening = 0.5} \\
\hline Baseline & 8558 & 0.721 & 0.03 & 0.65 & 0.79 & & \\
\hline VIX-only & 8558 & 0.526 & 0.03 & 0.46 & 0.59 & 21.47 & 0 \\
\hline FX-only & 8558 & 0.671 & 0.04 & 0.6 & 0.74 & 4.74 & 0.03 \\
\hline MP-only & 8558 & 0.716 & 0.03 & 0.65 & 0.78 & 0.41 & 0.52 \\
\hline \multicolumn{8}{|c|}{ Ordered (Weighted, non-FDI) Net Inflow Tightening = 1} \\
\hline Baseline & 8558 & 0.751 & 0.03 & 0.69 & 0.81 & & \\
\hline VIX-only & 8558 & 0.541 & 0.03 & 0.48 & 0.6 & 25.87 & 0 \\
\hline FX-only & 8558 & 0.746 & 0.03 & 0.69 & 0.8 & 0.48 & 0.49 \\
\hline MP-only & 8558 & 0.743 & 0.03 & 0.69 & 0.8 & 0.92 & 0.34 \\
\hline
\end{tabular}

Source: Author's calculations.

Notes: Each model is panel logit, with the dependent variable redefined to be a dichotomous variable. For example, in the first block of models, the dependent variable takes value 1 when the ordered (weighted, nonFDI) net inflow tightening variable $=-1$, and 0 otherwise. The final model has fewer observations because for at least one country in the sample, the model with the crisis dummy perfectly predicts action. These observations are dropped.

The AUROC for the baseline model varies between 0.66 and 0.74 for predicting policy actions, with standard errors of about 0.03 (Table 3). These AUROCs are similar to those achieved in the recent models for crisis prediction, e.g., the baseline models in Schularick and Taylor (2012). This suggests that the baseline model does reasonably well as a predictor of capital controls policy.

The baseline model also predicts better than simpler models (Table 3). The simpler models considered are: a VIX-only model with only VIX and a crisis dummy as explanatory variables, FX-only and MP-only models, which are the baseline models, but without the macroprudential, and mercantilist proxy respectively. Both MP-only and FX-only models are better than a coin toss and better than a VIX-only model, suggesting that each of the domestic factors plays a role in policy decisions. The baseline model improves over an MPonly or FX-only model in terms of AUROC, though the extent of improvement depends on the outcome being predicted, and for MP-only models is not significant. The FX-only models have an AUROC of between 0.6 and 0.74, with the highest AUROC for predicting strong tightening of inflow controls or strong easing of controls. For the strongest tightening, the FX-only model is indistinguishable from the baseline model, suggesting that mercantilist 
motivations play a role when policymakers decide to act decisively to tighten inflow controls. The difference in AUROCs between the MP-only and FX-only models may also be driven by the fact that the macroprudential motivations significantly change the probability of both net tightening and net easing of inflow controls, while mercantilist motivations act only on the tightening side, as shown in Figure 4 above. As we see later, the mercantilist motivation is more important in explaining net NKI restricting measures, which captures all available capital control tools to stem appreciation pressure.

As the capital controls index is based on qualitative information, one may ask how the interpretation of results is affected if the intensity of the changes is not perfectly captured. The dataset on capital controls captures the intensity of changes in two ways: (1) the capital controls data identifies the changes at a granular level-policy announcements are not the same as policy actions. A policy action is identified by splitting announcements along six dimensions, meaning that if policymakers were making bigger, "more intense" announcements in certain periods, e.g., during crisis periods, this should result in more counted actions in these periods. This is in fact the case with the index, as seen in Figure 8 below. Second, the index weights the actions by the share of the IIP category that the action affects, thus giving more weight to actions that affect a larger share of the country's balance sheet. Nevertheless, to the extent that the data don't capture intensity perfectly, we may underestimate the size of the responses (if policymakers systematically tightened more intensely than they eased, and we don't have that information). Therefore, we should interpret the results as capturing the minimum policy reaction. In this context, the finding that capital controls policy did react to mercantilist and macroprudential motivations gains even more significance, as the true coefficients may be even larger.

To summarize, the results so far suggest that both mercantilist and macroprudential motivations are important in predicting the use of inflow tightening measures. Moreover, the strongest inflow tightening actions respond more to mercantilist concerns.

\section{B. Exploring the Macroprudential Motivations: Do Capital Controls Target Foreign Credit?}

So far, the analysis has focused on a relatively simple model, with domestic bank credit to GDP gap as the only proxy for macroprudential motivations. As discussed in section II.A, recent literature specific to capital controls has recommended that capital controls be targeted to foreign borrowing, specifically foreign currency borrowing. Therefore, I tested a number of additional proxies for macroprudential motivations, sequentially adding them to the baseline model. The additional variables do not have significant average marginal effects on the predicted probabilities of net inflow tightening actions, with the exception of equity share of mutual fund inflows (Table 4). ${ }^{29}$ An increase in equity share of fund flows reduces the probabilities of taking a net inflow tightening actions and increases the probabilities of net easing actions, which is consistent with equity inflow being safer than debt inflows.

\footnotetext{
${ }^{29}$ To ensure consistency across models, all the models in Table 4 are run on the same observations as the smallest available data series - in this case, equity prices - so the baseline model in this table is not the same as in Table 2.
} 


\section{Table 4: Most Additional Macroprudential Proxies do not have Significant Average Marginal Effects}

\begin{tabular}{lccccc}
\hline & \multicolumn{5}{c}{ Average Marginal Effect on Pr(Net Inflow Tightening =i) } \\
& \multicolumn{4}{c}{ Probabilities expressed in percentage points } \\
& $i=-1$ & $i=-0.5$ & $i=0$ & $i=0.5$ & $i=1$ \\
\hline Bank credit to GDP gap (\%) & $-0.29^{*}$ & $-0.39^{*}$ & 0.18 & $0.27^{*}$ & $0.23^{*}$ \\
Balance Sheet Exposure & 0.01 & 0.01 & 0 & -0.01 & 0 \\
Bank Credit/GDP, (yoy gr) & -0.01 & -0.01 & 0 & 0 & 0 \\
Equity inflows/Total mutual fund inflows (\%, 12-wk & $0.08^{*}$ & $0.1^{*}$ & -0.05 & $-0.07^{*}$ & $-0.06^{*}$ \\
MA) & & & & & \\
Equity Prices (Trend Dev.) & -0.08 & -0.1 & 0.05 & 0.07 & 0.06 \\
Equity Prices (yoy gr) & 0.01 & 0.01 & 0 & -0.01 & -0.01 \\
External Credit, Non-banks (\% of GDP) & 0.05 & 0.06 & -0.03 & -0.04 & -0.04 \\
External Credit/GDP (\%) & -0.02 & -0.02 & 0.01 & 0.01 & 0.01 \\
External Credit/GDP (Trend Dev.) & -0.07 & -0.1 & 0.05 & 0.07 & 0.06 \\
External Credit/GDP (yoy gr, \%) & -0.07 & -0.09 & 0.04 & 0.06 & 0.05 \\
External Credit/GDP, Non-banks (yoy gr, \%) & -0.01 & -0.01 & 0.01 & 0.01 & 0.01 \\
External Debt Securities Net Flow (\% of GDP) & 0.11 & 0.15 & -0.07 & -0.11 & -0.09 \\
External Debt Securities Stock (\% of GDP) & -0.04 & -0.05 & 0.02 & 0.04 & 0.03 \\
Foreign Currency Debt Securities Stock (\% of GDP) & -0.04 & -0.05 & 0.02 & 0.03 & 0.03 \\
Foreign Currency Debt Securities Stock (Trend & -0.05 & -0.07 & 0.03 & 0.05 & 0.04 \\
Dev.) & & & & & \\
Foreign Currency Debt Securities, Net Flows (\% of & 0.11 & 0.15 & -0.07 & -0.1 & -0.09 \\
GDP) & & & & & \\
Foreign Currency Debt Securities, Short Term, Net & -0.01 & -0.01 & 0.01 & 0 & 0 \\
Flows (\% of GDP) & & & & & -0.05 \\
Other Investment Inflows/GDP (Trend Dev.) & 0.06 & 0.09 & -0.04 & -0.06 & -0.05 \\
Other Investment/GDP (\%) & 0.11 & 0.14 & -0.07 & -0.1 & -0.08 \\
Portfolio Liabilities/Total External Liabilities (\%) & 0.02 & 0.02 & -0.01 & -0.02 & -0.01 \\
Residential Property Prices (yoy gr, \%) & 0.07 & 0.11 & -0.05 & -0.07 & -0.06 \\
\hline
\end{tabular}

Source: Authors' calculations.

Note: Dependent variable is the ordered weighted, non-FDI net inflow tightening measures. Estimation method is panel ordered logit, assuming random effects and using robust standard errors.

An interesting result in Table 4 is that capital controls are acyclical on average to foreign or foreign currency debt while they are countercyclical to the domestic bank credit gap. ${ }^{30}$ This means that regulators prevent domestic residents from borrowing abroad when domestic banks are lending at a brisk pace, and ease restrictions on foreign borrowing when domestic banks credit is growing slowly-however they do not systematically respond to changes in foreign credit itself. The tightening of controls on foreign credit when domestic credit is booming may simply reflect that regulators find it easier to restrict foreign credit than

\footnotetext{
${ }^{30}$ Note that the correlation between bank credit gap and external credit gap are significant for most countries, as shown in Table A2, and it's reasonable to question whether the insignificance of the results is due to multicollinearity. However, this is not the case, as even in specifications excluding bank credit to GDP gap, the coefficients for foreign credit variables are not significant. Moreover, many correlations between external and domestic credit gaps are negative and signficant, suggesting that the domestic and foreign credit booms do not happen at the same time.
} 
domestic credit, because of lack of adequate domestic prudential tools or because of shortcomings of domestic institutional frameworks. For example, if regulators can do little to stem excessive lending to politically preferred sectors in economies where state banks dominate domestic lending, they may prefer to change restrictions on foreign credit to manage total credit in the economy.

While capital controls may not be countercyclical to foreign credit on average, it may be that regulators focus on external credit more when it is already high. To test this, I conduct a counterfactual experiment. I run the following specification, which uses the foreign currency debt securities stock (deviation from trend) as the macroprudential proxy and interacts both the mercantilist and macroprudential proxies by a dummy variable that takes the value 1 when the measure of foreign credit is more than two standard deviations above its countryspecific mean, and zero otherwise:

$$
\begin{aligned}
& \operatorname{Pr}\left(y_{i t}=s_{j} \mid w_{i t-1}\right)=f\left\{D\left(X_{i t-1}^{M P} \geq 2\right) * X_{i t-1}^{M P} \beta^{D M P}+X_{i t-1}^{M P} \beta^{M P}\right. \\
& \left.+D\left(X_{i t-1}^{M P} \geq 2\right) * X_{i t-1}^{F X} \beta^{D F X}+X_{i t-1}^{F X} \beta^{F X}+X_{t}^{G} \beta^{G}+X_{i t-1}^{O} \beta^{O}\right\}
\end{aligned}
$$

\section{Figure 6: Policy Reaction Function Changes in High Foreign Currency Debt States}

Average marginal effect of high foreign currency debt state on probability of net inflow tightening $>0$

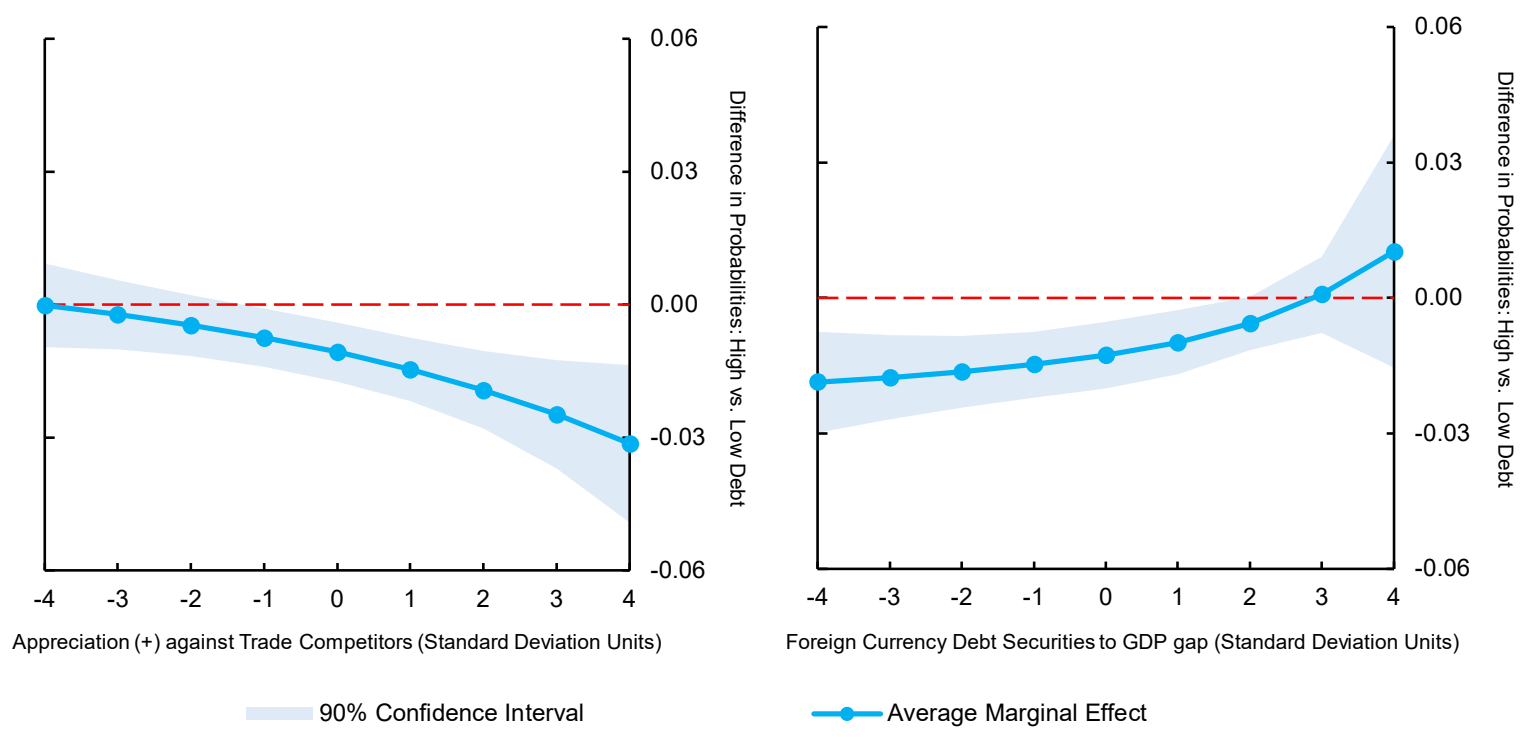

Source: Author's calculations.

Note: The figure computes the average marginal effects for the model with the country-specific mercantilism proxy. 
High stock of foreign currency debt securities relative to trend changes the reaction function. Figure 6 plots the average marginal effects of the high foreign currency debt state on the probability of a positive net inflow tightening action, for different values of mercantilism and macroprudential proxies. If all countries behaved as if they were in high foreign currency debt state, they would be less likely to tighten inflow controls to stem appreciation against trade competitors, and also less likely to tighten inflow controls when foreign currency debt gap is low. That is, the reaction function becomes less countercyclical in response to appreciation against trade competitors and more countercyclical to foreign currency debt gap. However, even in this extreme case, higher foreign currency debt does not significantly increase the probability of a tightening -the increase in countercyclicality comes only from the left end of the tail.

\section{Exploring the Mercantilist Motivation}

\section{Predicting net NKI Restricting Actions}

The analysis so far has examined the motivations for changing controls on capital inflows. Yet, countries have another tool to resist exchange rate appreciations: the easing of outflow restrictions (Aizenman and Pasricha, 2013). In this section, I analyze the motivations for changing Net NKI restricting actions, defined as the sum of net inflow tightening actions and net outflow easing actions.

The results show that net NKI restricting actions respond systematically only to mercantilist concerns (Table 5). The size and significance of the estimated proportional odds ratios for mercantilism proxies in Table 5 is higher than those in Table 2 for net inflow tightening actions. Increases in the credit-to-GDP gap do not significantly increase the odds of net NKI restricting actions. Further, appreciation against trade competitors on average significantly increases the predicted probability of positive net NKI restricting measures, while also significantly decreasing the probability of easing net restrictions on NKI (Figure 7). On the other hand, the average marginal effect of bank credit to GDP gap on the probability of net NKI restricting actions is not significant for any outcome. Figure 8 supports these results by showing a close correspondence between net NKI restricting actions and exchange market pressure.

The results of Table 5 and Table 2 together imply that countries use both inflow tightening and outflow easing actions to respond systematically to mercantilist concerns, but use only inflow tightening actions to respond to macroprudential concerns. This is further evidence that policy is carefully calibrated: outflow easings do not directly reduce systemic risk but can mitigate exchange rate pressures. 
Table 5: Net NKI Restricting Actions Respond only to Mercantilist Concerns

\begin{tabular}{|c|c|c|c|c|c|c|}
\hline & \multicolumn{6}{|c|}{ Dependent Variable: Weighted Net NKI Restrictions (non-FDI) } \\
\hline & (1) & (2) & (3) & (4) & (5) & (6) \\
\hline Mercantilism Proxy (Country-Specific) & $1.30^{* * *}$ & & & & & \\
\hline Mercantilism Proxy (Nominal, 13-wk appr, \%) & & $1.21^{* *}$ & & & & \\
\hline Mercantilism Proxy (Real, 13-wk appr, \%) & & & $1.21^{\star \star}$ & & & \\
\hline Mercantilism Proxy (Nominal, yoy appr, \%) & & & & $1.22^{* * *}$ & & \\
\hline Mercantilism Proxy (Real, yoy appr, \%) & & & & & $1.21^{* *}$ & \\
\hline Exchange rate vs. USD (Nominal, 13-wk appr, \%) & & & & & & $1.51^{* * *}$ \\
\hline Bank Credit-GDP gap (\%) & 1.12 & 1.11 & 1.12 & 1.11 & 1.12 & 1.12 \\
\hline Previous policy action $(\mathrm{T}, \mathrm{E})$ & 1.06 & 1.08 & 1.08 & 1.07 & 1.07 & 1.08 \\
\hline Fiscal Stance & 1.13 & 1.13 & 1.13 & 1.13 & 1.13 & 1.12 \\
\hline Monetary Stance & $0.83^{* *}$ & $0.83^{* *}$ & $0.83^{* *}$ & $0.83^{* *}$ & $0.83^{* *}$ & 0.86 \\
\hline$\Delta$ Reserves/GDP (\%, residuals) & $1.42^{* \star *}$ & $1.42^{* * *}$ & $1.42^{\star \star \star}$ & $1.41^{* * *}$ & $1.41^{* * *}$ & $1.28^{\star \star *}$ \\
\hline Inflation & 1.00 & 0.98 & 0.97 & 1.03 & 0.99 & 0.95 \\
\hline VIX & $0.99^{* *}$ & $0.99^{* *}$ & $0.99^{* *}$ & $0.99^{* * *}$ & $0.99^{* *}$ & 1.00 \\
\hline Crisis Dummy & 1.05 & 0.97 & 0.94 & 0.99 & 0.91 & 1.24 \\
\hline Observations & 10,114 & 10,114 & 10,114 & 10,114 & 10,114 & 10,106 \\
\hline Number of Countries & 13 & 13 & 13 & 13 & 13 & 13 \\
\hline Pseudo-Log Likelihood & -2076 & -2082 & -2082 & -2082 & -2082 & -2061 \\
\hline Chi-Squared (All coefficients $=0$ ) & 182.3 & 161.3 & 170.1 & 191.8 & 202.3 & 548.2 \\
\hline P-value (Chi-Squared) & 0 & 0 & 0 & 0 & 0 & 0 \\
\hline
\end{tabular}

Source: Author's calculations.

Notes: Reported values are proportional odds ratios. Sample period is 2001w1-2015w52. All domestic control variables are one-week lagged. All continuous domestic variables are standardized but centered at 0 , i.e., the variables are divided by their standard deviation but not demeaned. Monetary policy stance and fiscal policy stance are variables that take the value +1 if monetary policy is tightened in the previous week (or structural balance improves), -1 for expansionary policies and 0 otherwise. $\Delta$ Reserves/GDP are residuals from regressions in Table 1. Robust standard errors used. ${ }^{* * *} p<0.01,{ }^{* *} p<0.05,{ }^{*} p<0.10$

\section{Additional Proxies for Mercantilist Motivation}

So far, the analysis has focused on the new proxies for mercantilist motivations proposed in this paper. Here, I explore additional proxies for mercantilist motivations, suggested by the empirical and theoretical literature. These include growth rate of a country's GDP relative to the U.S. and its relative manufacturing IIP growth rate (Costinot, Lorenzoni and Werning, 2014), as well as export volume growth, which is used in the existing empirical literature on reserves accumulation. The additional variables are not significant (Table 6). 


\section{Figure 7: Average Marginal Effects: Baseline Model for Net NKI} Restrictions

(a) Mercantilism Proxy

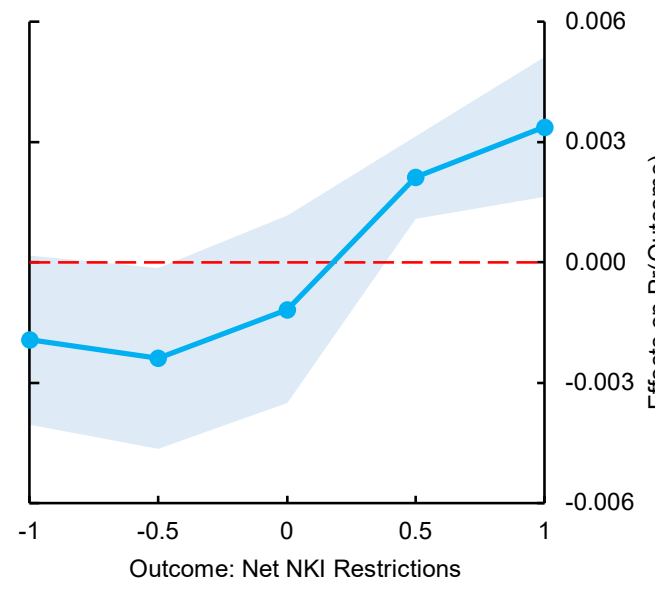

$90 \%$ Confidence Interval (b) Macroprudential Proxy

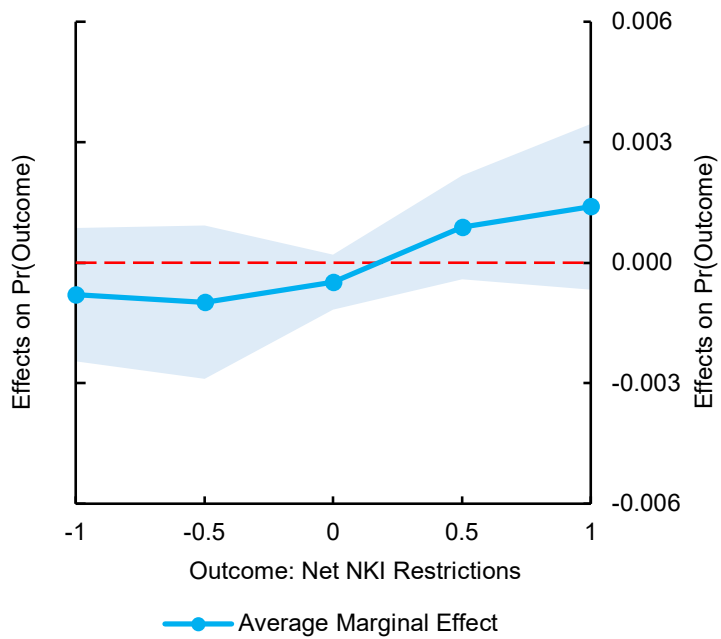

Source: Author's calculations.

Note: The figure computes the average marginal effects for the baseline model with the country-specific mercantilism proxy.

\section{Figure 8: Net NKI Restricting Measures Respond Strongly to Appreciation Pressures Against U.S. Dollar}

26 Week (2 Quarter) Moving Averages

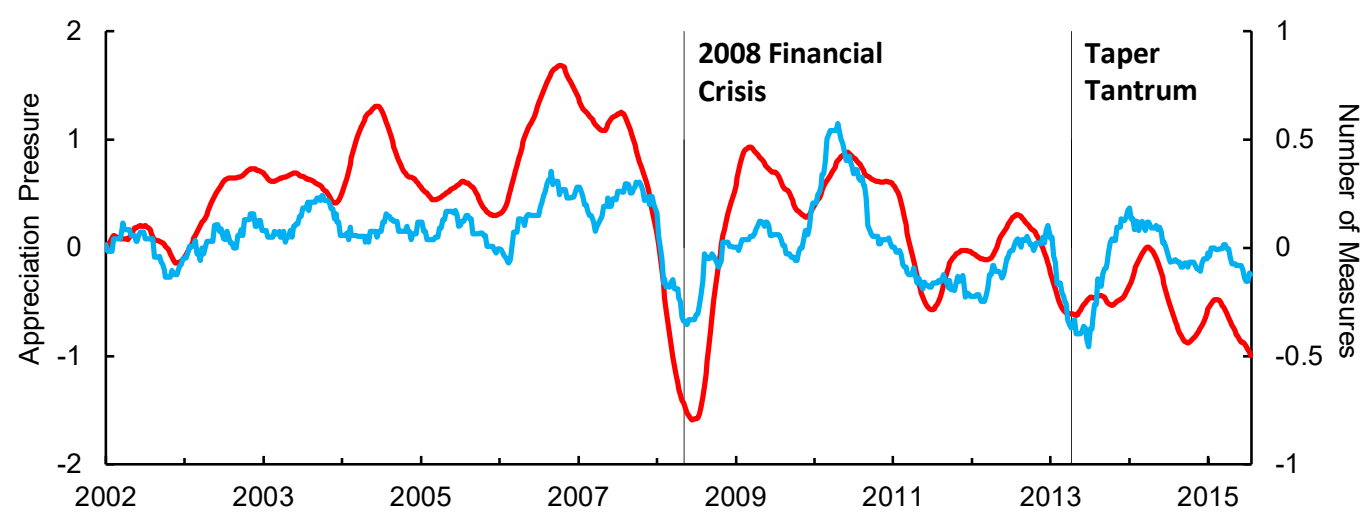

Exchange Market Pressure (left)

Number of Net NKI Restricting Actions (Wgt, non-FDI)

Source: IMF International Financial Statistics, Datastream and Author's calculations.

Note: Exchange market pressure index is the EME average. Each emerging market's EMP is computed as the sum of standardized appreciation in nominal exchange rate against U.S. dollar and standardized percentage increase in foreign exchange reserves excluding gold. The reserves series is interpolated from quarterly data before computing percentage changes. Net NKI Restricting actions are computed as (Inflow Tightenings - Inflow Easings) + (Outflow Easings Outflow Tightenings). The measures are weighted and exclude those related to FDI but include currency-based measures.

Last Observation: 2015w52. 
Table 6: Additional Mercantilism Proxies are not Significant

\begin{tabular}{|c|c|c|c|c|c|}
\hline & \multicolumn{5}{|c|}{ Dependent Variable: Weighted Net Inflow Tightenings (non-FDI) } \\
\hline & (1) & (2) & (3) & (4) & (5) \\
\hline Mercantilism Proxy (Country-Specific) & $1.35^{\star \star \star}$ & $1.36^{\star \star \star}$ & $1.36^{\star \star \star}$ & $1.37^{\star \star \star}$ & $1.35^{\star \star}$ \\
\hline Bank Credit-GDP gap (\%) & $1.32^{\star * *}$ & $1.33^{\star \star *}$ & $1.32^{\star \star \star}$ & $1.36^{\star * *}$ & $1.35^{\star \star \star}$ \\
\hline Relative GDP Growth & & 0.97 & & & \\
\hline Manufacturing IIP Growth & & & 0.98 & & \\
\hline Relative Manufacturing IIP Growth & & & & 0.90 & \\
\hline Export Volume Growth (yoy, \%) & & & & & 1.00 \\
\hline Previous policy action ( $\mathrm{T}, \mathrm{E})$ & $1.28^{* * *}$ & $1.29^{* * *}$ & $1.29^{* * *}$ & $1.30^{* * *}$ & $1.31^{* \star \star}$ \\
\hline Fiscal Stance & $1.17^{* *}$ & $1.17^{* \star}$ & $1.18^{* *}$ & $1.16^{\star \star}$ & $1.16^{*}$ \\
\hline Monetary Stance & $0.86^{* *}$ & $0.86^{* *}$ & $0.86^{* *}$ & $0.86^{* *}$ & $0.87^{*}$ \\
\hline$\Delta$ Reserves/GDP $(\%$, residuals $)$ & $1.33^{* * *}$ & $1.34^{* * *}$ & $1.34^{* * *}$ & $1.36^{* * *}$ & $1.26^{*}$ \\
\hline Inflation & 1.03 & 1.03 & 1.03 & 1.01 & 1.00 \\
\hline VIX & 0.99 & 0.99 & 0.99 & 1.00 & 0.99 \\
\hline Crisis Dummy & 0.43 & 0.44 & 0.44 & 0.45 & 0.38 \\
\hline Observations & 6,769 & 6,769 & 6,762 & 6,762 & 5,064 \\
\hline Number of Countries & 11 & 11 & 11 & 11 & 9 \\
\hline Pseudo-Log Likelihood & -1585 & -1585 & -1585 & -1584 & -1296 \\
\hline
\end{tabular}

Source: Author's calculations.

Notes: Reported values are proportional odds ratios. Sample period is 2001w1-2015w52. All domestic control variables are one-week lagged. All continuous domestic variables are standardized but centered at 0 , i.e., the variables are divided by their standard deviation but not demeaned. Monetary policy stance and fiscal policy stance are variables that take the value +1 if monetary policy is tightened in the previous week (or structural balance improves), -1 for expansionary policies and 0 otherwise. $\Delta$ Reserves/GDP are residuals from regressions in Table 1. Robust standard errors used. ${ }^{* *} p<0.01,{ }^{* *} p<0.05,{ }^{*} p<0.10$

\section{What Drives the Weights on the two Motivations: The Role of Exchange Rate Pass- Through and Monetary and Exchange Rate Regimes}

If, from an international policy coordination perspective, it is important that capital controls should respond only to macroprudential concerns, then we need to understand if there are any structural factors that drive the relative weight of the two motivations in the policy reaction function. In this section, I explore two such factors: the degree of sensitivity of a country's export prices to exchange rate changes, and the role of inflation targeting and non-freely floating regimes.

High exchange rate pass-through (ERPT) to export prices means that the exporter's trading partners bear more of the cost of the exporting country's currency appreciation. This means that the country's exports are potentially more sensitive to that appreciation, and policymakers may in turn respond more to stem such appreciation. To test this, I use a dummy variable, which equals 1 for countries with greater than median export price ERPT and add it as an interaction term in the baseline specification for net NKI restricting measures. I use Bussière, Gaulier and Steingress's (2016) baseline (no fixed effects) estimates of export price elasticities to construct the dummy variable. That is, I run the following specification: 


$$
\begin{aligned}
& \operatorname{Pr}\left(y_{i t}=s_{j} \mid w_{i t-1}\right)=f\left\{X_{i t-1}^{M P} \beta^{M P}+D(\text { High ERPT }) * X_{i t-1}^{M P} \beta^{D M P}\right. \\
& \left.+X_{i t-1}^{F X} \beta^{F X}+D(H i g h E R P T) * X_{i t-1}^{F X} \beta^{D F X}+\mathrm{X}_{t}^{G} \beta^{G}+\mathrm{X}_{i t-1}^{O} \beta^{O}\right\},
\end{aligned}
$$

where the dependent variable is net NKI restricting measures and the mercantilist proxy is the country-specific proxy.

The results show that countries with high ERPT to export prices respond more strongly to competitiveness changes against trade competitors than low ERPT countries (Figure 9). ${ }^{31}$

I conduct a similar exercise with a dummy variable that equals 1 for countries that have an inflation target and a non-freely floating regime, as identified in the IMF AREAER. I find that these regimes are also more responsive to mercantilist motivations (Figure 10). They are also less responsive to macroprudential motivations. ${ }^{32}$

\footnotetext{
${ }^{31}$ The full results of the regressions are available on request.

${ }^{32}$ Results not shown but available on request.
} 


\section{Figure 9: Countries with high Exchange Rate Pass-Through to Export Prices Respond more to Mercantilist Concerns}

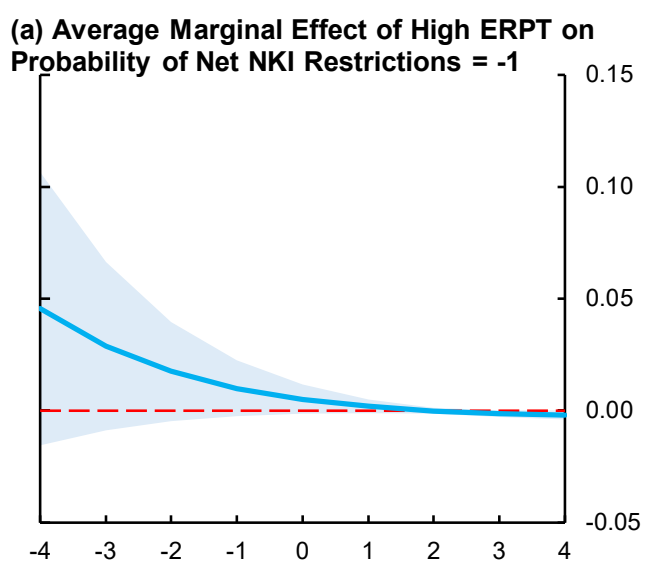

Appreciation (+) against Trade Competitors (Standard Deviation Units)

(c) Average Marginal Effect of High ERPT on Probability of Net NKI Restrictions $=0$

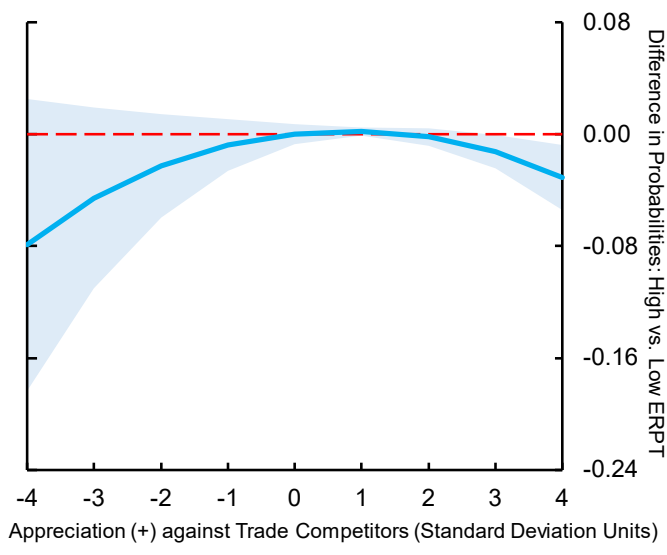

(b) Average Marginal Effect of High ERPT on

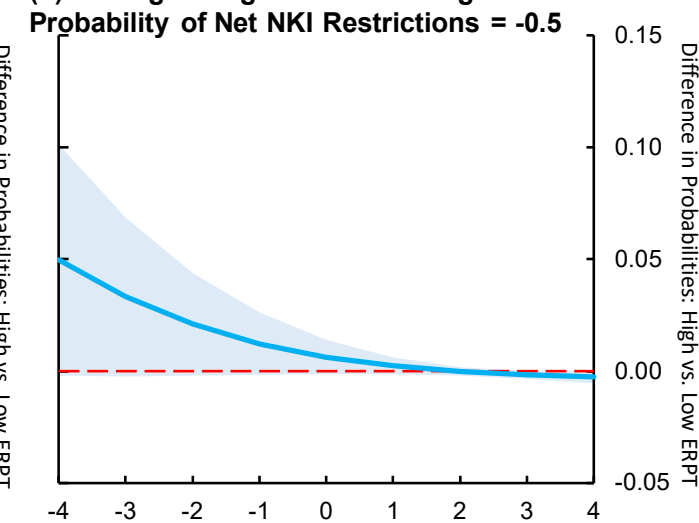

Appreciation (+) against Trade Competitors (Standard Deviation Units)

(d) Average Marginal Effect of High ERPT on Probability of Net NKI Restrictions $=0.5$

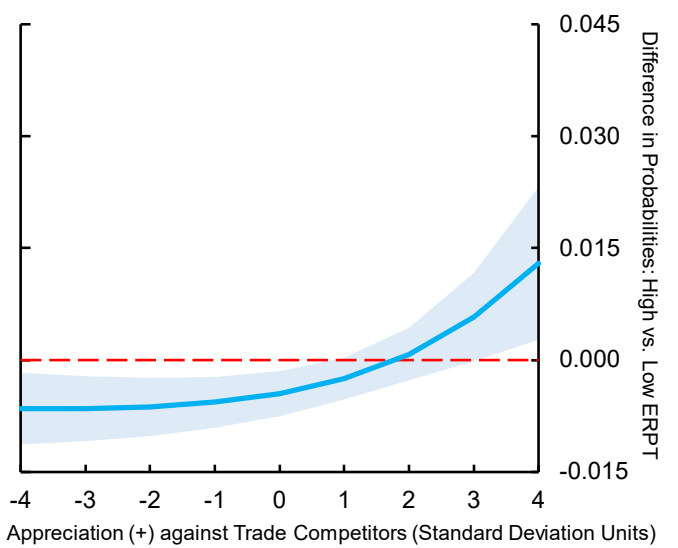

(e) Average Marginal Effect of High ERPT on Probabilityof Net NKI Restrictions $=1$

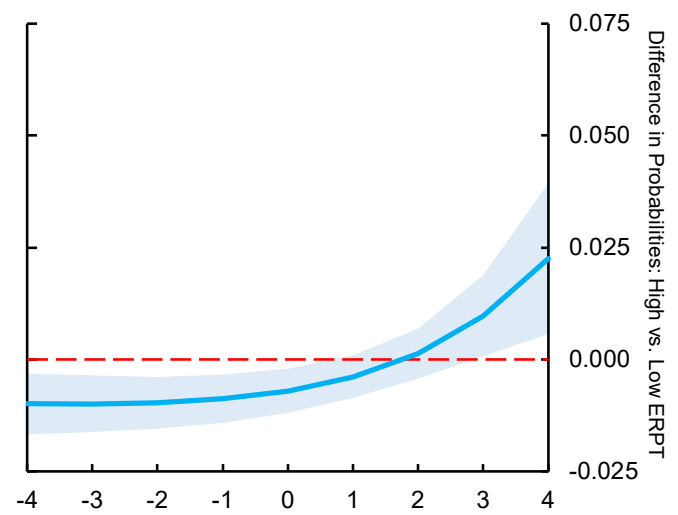

Appreciation (+) against Trade Competitors (Standard Deviation Units)

$90 \%$ Confidence Interval Average Marginal Effect

Source: Author's calculations. 


\section{Figure 10: Inflation Targeting and Non-Freely Floating Exchange Rate Regimes Respond more to Mercantilist Concerns}

(a) Average Marginal Effect of IT and non-FF on Net Inflow Tightening $=-1$

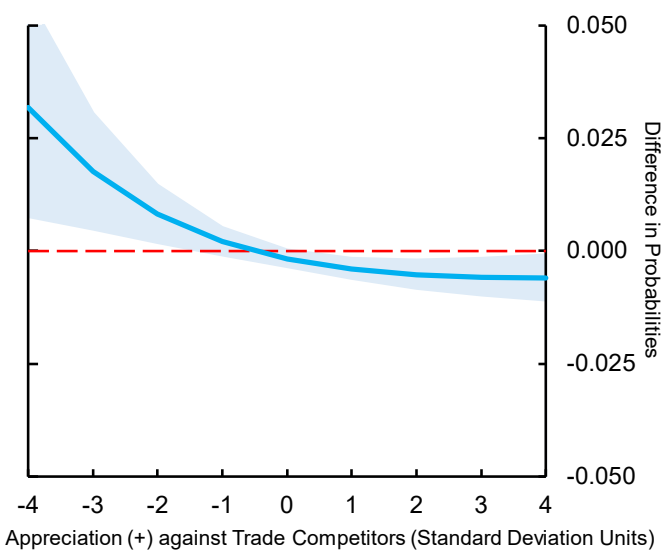

(c) Average Marginal Effect of IT and non-FF on Net Inflow Tightening $=0$

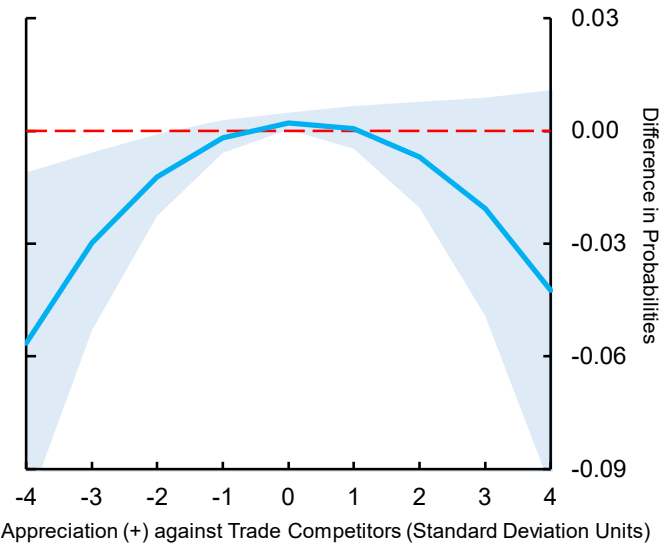

(b) Average Marginal Effect of IT and non-FF on Net Inflow Tightening $=\mathbf{- 0 . 5}$

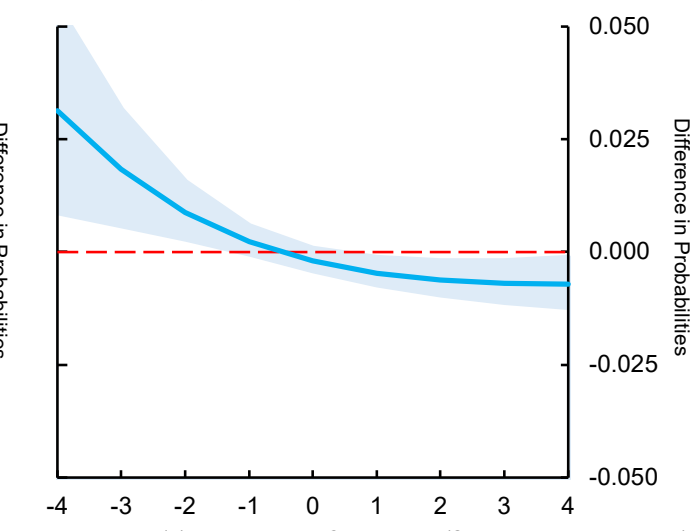

Appreciation (+) against Trade Competitors (Standard Deviation Units)

(d) Average Marginal Effect of IT and non-FF on Net Inflow Tightening $=0.5$

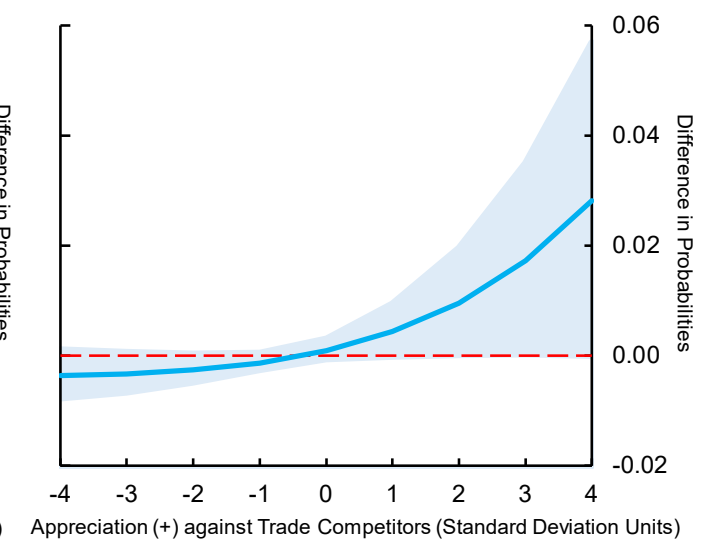

(e) Average Marginal Effect of IT and non-FF on Net Inflow Tightening $=1$

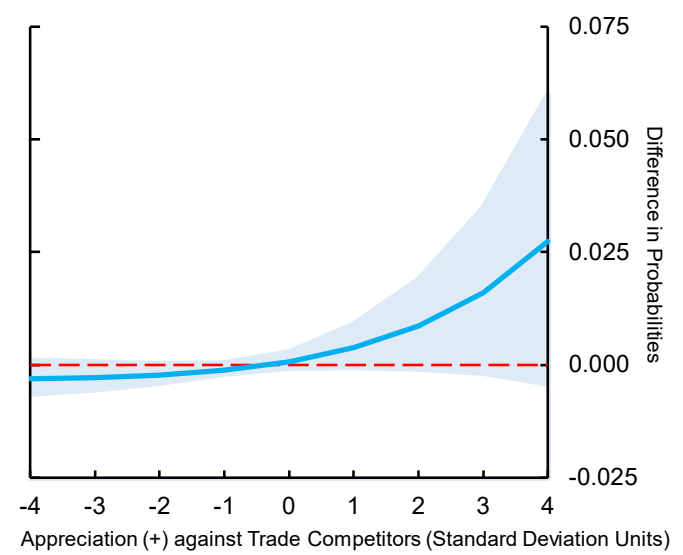

$90 \%$ Confidence Interval

_ Average Marginal Effect

Source: Author's calculations. 


\section{ROBUSTNESS CHECKS}

I conduct two types of robustness checks: first, on the mercantilist proxy as a valid measure of mercantilist motivations; and second, robustness checks on the baseline specifications.

\section{A. Mercantilist Proxy as a Valid Measure of Mercantilist Motivations}

To validate the mercantilism proxy, I test whether it predicts non-tariff barriers to trade imposed by countries. I use data on non-tariff measures (NTMs) applied on trade from the World Trade Organization's (WTO) I-TIP portal. To download the data, I used web-scraping techniques in Python, as the I-TIP portal doesn't allow changing both the time and country dimension at the same time. The data I use includes four types of NTMs: anti-dumping duties, quantitative restrictions, countervailing duties and safeguards. I download three weekly series for each country: the number of measures coming into force, initiated and withdrawn during the week. I also compute net initiations as the number of measures initiated, less those withdrawn during a given week.

It is important to note that the trade barriers data does not capture all the activism on trade policy, for several reasons: one, the data doesn't cover the full universe of trade barriers countries can take, due to concerns about the timeliness and completeness of data on certain measures; ${ }^{33}$ and second, that countries could respond by raising tariffs as well. It is important to also note that there may be long time lags between competitiveness pressures arising and countries initiating trade measures or enforcing them. Even with these caveats in mind, a strong correlation or causality between mercantilism proxies and future NTMs would suggest that the proxies are indeed capturing mercantilist concerns.

The unconditional correlations between the mercantilism proxies and the future initiations, coming into force or net initiations of non-tariff barriers are positive and significant (Table 7). These contrast with their correlations with appreciation against the U.S. dollar, which are low or negative. The positive correlations between mercantilism proxies and trade barriers suggest that the proxies do capture concerns about trade competitiveness. The correlations for several individual countries are much larger than for the group, reaching about 0.5 for Argentina and Poland (Figure 11).

To explore these relationships further, I test whether the mercantilism proxies Granger cause any of the measures of non-tariff barriers (Table 8). For each country and series pair, I first select the optimal lag length from VARs with up to 52 lags (i.e., up to 52 weeks, or one year), using AIC statistic. Next, I conduct the Granger causality tests for net initiations and measures coming into force, using the optimal lag length. ${ }^{34}$ I find that for 16 out of the 21 countries in sample, and in 11 out of the 13 active countries, there is evidence of Granger causality from at least one of the mercantilism proxies to one of the non-tariff barriers series. The year over year nominal appreciation against trade competitors Granger causes measures entering into force over the following year in 10 countries. In the other 6 countries, the causality is to net measures initiated.

\footnotetext{
${ }^{33}$ These include sanitary and phytosanitary measures, technical barriers to trade, and measures from the Agreement on Agriculture.

${ }^{34}$ The full Granger causality results, including degrees of freedom for each test are available on request.
} 
Table 7: Mercantilism Proxies are Positively Correlated with Future Non-tariff Measures

\begin{tabular}{|c|c|c|c|c|c|c|c|c|}
\hline & \multicolumn{4}{|c|}{ All countries } & \multicolumn{4}{|c|}{13 active countries } \\
\hline & $\begin{array}{l}\text { Measures } \\
\text { Inforce }\end{array}$ & $\begin{array}{l}\text { Measures } \\
\text { Withdrawn }\end{array}$ & $\begin{array}{l}\text { Measures } \\
\text { Initiated }\end{array}$ & $\begin{array}{l}\text { Net } \\
\text { Initiations }\end{array}$ & $\begin{array}{l}\text { Measures } \\
\text { Inforce }\end{array}$ & $\begin{array}{l}\text { Measures } \\
\text { Withdrawn } \\
\end{array}$ & $\begin{array}{l}\text { Measures } \\
\text { Initiated }\end{array}$ & $\begin{array}{l}\text { Net } \\
\text { Initiations } \\
\end{array}$ \\
\hline $\begin{array}{l}\text { Mercantilism Proxy (Nominal, } \\
\text { 13-wk appr., \%, 1-y MA) }\end{array}$ & $0.05^{\star * *}$ & -0.01 & $0.03^{* * *}$ & $0.04^{* * *}$ & $0.06^{* * *}$ & 0.00 & $0.04^{* * *}$ & $0.05^{* * *}$ \\
\hline $\begin{array}{l}\text { Mercantilism Proxy (Real, 13-wk } \\
\text { appr., \%, 1-y MA) }\end{array}$ & $0.11^{* * *}$ & $-0.02^{* *}$ & $0.03^{* * *}$ & $0.05^{\star * *}$ & $0.13^{* * *}$ & $-0.03^{* *}$ & $0.03^{* * *}$ & $0.06^{* * *}$ \\
\hline $\begin{array}{l}\text { Mercantilism Proxy (Nominal, } \\
\text { yoy appr., \%,) }\end{array}$ & $0.05^{* * *}$ & $-0.04^{\star * *}$ & 0.01 & $0.04^{* * *}$ & $0.07^{\star * *}$ & $-0.02^{*}$ & $0.03^{* *}$ & $0.05^{\star * *}$ \\
\hline $\begin{array}{l}\text { Mercantilism Proxy (Real, yoy } \\
\text { appr., \%) }\end{array}$ & $0.10^{* * *}$ & $-0.04^{* * *}$ & 0.01 & $0.05^{* * *}$ & $0.13^{* * *}$ & $-0.05^{\star \star *}$ & 0.01 & $0.05^{\star * *}$ \\
\hline $\begin{array}{l}\text { Exchange rate vs. USD } \\
\text { (Nominal, 13-wk appr., \%, 1-yr } \\
\text { MA) }\end{array}$ & 0.01 & $-0.08^{* * *}$ & $-0.09^{* * *}$ & $-0.04^{* * *}$ & $0.06^{* * *}$ & $-0.05^{* * *}$ & $-0.04^{* * *}$ & -0.00 \\
\hline $\begin{array}{l}\text { Exchange rate vs. USD } \\
\text { (Nominal, yoy appr., \%) }\end{array}$ & 0.00 & $-0.07^{\star * \star}$ & $-0.07^{* \star *}$ & $-0.04^{\star * *}$ & $0.05^{\star \star *}$ & $-0.03^{*}$ & $-0.02^{*}$ & -0.01 \\
\hline Number of observations & 16380 & 16380 & 16380 & 16380 & 10140 & 10140 & 10140 & 10140 \\
\hline
\end{tabular}

\section{Figure 11: Mercantilism Proxies are Positively Correlated with Future Net Initiations of Non-tariff Barriers in all but Three Countries}

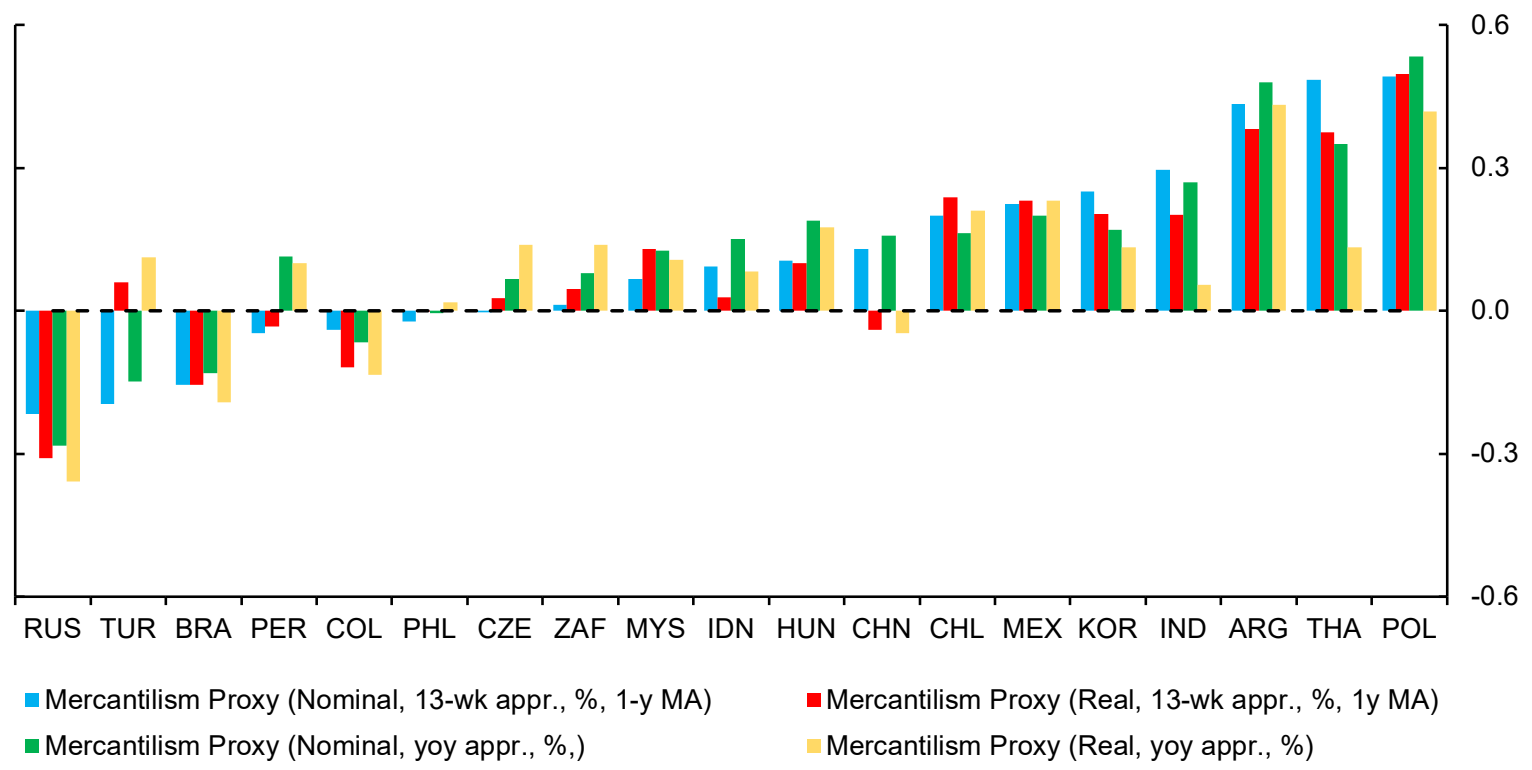

Source: Author's calculations.

Note: The figure plots the correlations of past appreciation of currency against trade competitors with future initiations of non-tariff barriers. 1-y Ma refers to a 52-week backward looking moving average. Future net initiatior of non-tariff barriers refer to a forward looking 52-week moving average of net initiations of non-tariff barriers. 
Table 8: Granger Causality Tests: $\mathbf{X}^{2}$ Statistics

\begin{tabular}{|c|c|c|c|c|c|c|c|c|}
\hline \multirow{2}{*}{$\begin{array}{l}\mathrm{A} \rightarrow \\
\mathrm{B} \rightarrow\end{array}$} & \multicolumn{2}{|c|}{$\begin{array}{l}\text { Mercantilism Proxy } \\
\text { (Real, yoy appr., \%) }\end{array}$} & \multicolumn{2}{|c|}{$\begin{array}{l}\text { Mercantilism Proxy } \\
\text { (Nominal, yoy appr., } \\
\%, \text { ) }\end{array}$} & \multicolumn{2}{|c|}{$\begin{array}{l}\text { Mercantilism Proxy } \\
\text { (Real, 13-wk appr.) }\end{array}$} & \multicolumn{2}{|c|}{$\begin{array}{c}\text { Mercantilism Proxy } \\
\text { (Nominal, 13-wk appr., } \\
\% \text { ) }\end{array}$} \\
\hline & $\begin{array}{c}\text { Measures } \\
\text { in Force }\end{array}$ & $\begin{array}{l}\text { Net } \\
\text { Initiations } \\
\end{array}$ & $\begin{array}{l}\text { Measures } \\
\text { in Force }\end{array}$ & $\begin{array}{c}\text { Net } \\
\text { Initiations } \\
\end{array}$ & $\begin{array}{l}\text { Measures } \\
\text { in Force }\end{array}$ & $\begin{array}{c}\text { Net } \\
\text { Initiations } \\
\end{array}$ & $\begin{array}{l}\text { Measures } \\
\text { in Force }\end{array}$ & $\begin{array}{l}\text { Net } \\
\text { Initiations } \\
\end{array}$ \\
\hline ARG & $26.4^{*}$ & 6.9 & 13.2 & 8.5 & 13.9 & $32.3^{*}$ & 12.5 & 26.7 \\
\hline BRA & 28.2 & 0.7 & $59.1^{*}$ & 1 & 27.3 & 28.3 & 27.1 & 28.5 \\
\hline $\mathrm{CHL}$ & 4.2 & 9.4 & $6.6^{*}$ & 8.7 & 30.6 & 4.1 & 31.6 & 3.8 \\
\hline $\mathrm{CHN}$ & 21.3 & 7.8 & $23.7^{\star}$ & 6.7 & 27.1 & 56.7 & 25.1 & 52.5 \\
\hline $\mathrm{COL}$ & 3.2 & 1.4 & 2.2 & 1.5 & $61.1^{*}$ & $44.1^{*}$ & $98.8^{*}$ & $70.9^{*}$ \\
\hline CZE & $82.8^{*}$ & 59.1 & $86.8^{*}$ & 64.3 & $105.3^{*}$ & 48.5 & $104.7^{*}$ & 57.7 \\
\hline EGY & 1.9 & 2.3 & 1.8 & 1.8 & 19.5 & 10.7 & 19.7 & 15.4 \\
\hline HUN & $82.2^{*}$ & $69^{*}$ & $85.7^{*}$ & $69.9^{*}$ & $81.5^{\star}$ & 65.2 & $83.1^{*}$ & 64.8 \\
\hline IDN & 56.9 & 2 & 58.6 & 5 & 27.3 & $40.5^{\star}$ & 27.7 & $56.5^{*}$ \\
\hline IND & 0.7 & 8.5 & $5.1^{*}$ & 3.7 & 15.4 & 21.9 & 17 & 7.8 \\
\hline KOR & 0.7 & 0.7 & 0.5 & 0.5 & 12.9 & 14.7 & 13 & 23.2 \\
\hline MAR & 1.2 & 3 & 1 & 2.7 & 17.2 & 17.5 & 17 & 16.5 \\
\hline MEX & 11.5 & 0.6 & 12.4 & 0.5 & 21.3 & 15.9 & 21.5 & 16.4 \\
\hline MYS & 2.4 & 28 & 1.4 & $32.5^{*}$ & $37.3^{*}$ & $45^{\star}$ & $37.1^{*}$ & $44.5^{\star}$ \\
\hline PER & 1.5 & 0.2 & 1.7 & 0.1 & 7.2 & 6.1 & 7.5 & 6 \\
\hline $\mathrm{PHL}$ & $172.8^{*}$ & $118^{*}$ & $203.9^{*}$ & $128.3^{*}$ & $83.6^{*}$ & $107.8^{*}$ & $72.1^{*}$ & $103.9^{*}$ \\
\hline POL & $14.2^{*}$ & 7.5 & $13.9^{*}$ & $10.1^{*}$ & 28.1 & 35.5 & 26 & 35 \\
\hline RUS & $35.4^{*}$ & $29.3^{*}$ & $32.3^{*}$ & $29.1^{*}$ & $56.7^{*}$ & 16.7 & $57.6^{*}$ & 16.5 \\
\hline THA & $37.1^{*}$ & $12.1^{*}$ & $36.7^{*}$ & $5.3^{*}$ & 37.9 & $34.8^{*}$ & 36.9 & $33.9^{*}$ \\
\hline TUR & 12.7 & 8.7 & 12.6 & 6.2 & 35.4 & $59.7^{\star}$ & 37.7 & $58.6^{*}$ \\
\hline ZAF & 1.6 & $27.7^{*}$ & 1.5 & $26.8^{*}$ & 15.1 & $108.1^{*}$ & 14.9 & $54.1^{*}$ \\
\hline
\end{tabular}

Source: Author's calculations.

Note: Degrees of freedom not shown, as they vary by country and series pair. Full results available on request. The number of observations per country vary from 623 to 773 , and the number of lags vary between 2 and 52 . The optimal lag length for each country was selected using AIC. ${ }^{* *} p<0.01,{ }^{* *} p<0.05,{ }^{*} p<0.10$. Non-tariff barriers are 52-week forward looking moving averages.

\section{B. Robustness Checks on the Baseline Specifications}

The results presented above are robust to a number of alterations in specifications. First, I use alternative measures of capital controls policy (Table 9, columns 1-3). I run the baseline specifications without reducing the number of ordered categories. This leads to estimation of a large number of cut-offs for the latent variable but doesn't affect the sign or significance (or the approximate size) of the estimated coefficients. Using unweighted policy actions as the dependent variable does not change the results. Estimating the reaction functions for all policy actions, including those affecting FDI, leads to a small decline in the estimated coefficient on bank credit gap in the baseline regression explaining net inflow tightening actions, but the coefficient is still significant. The other results are robust to including FDIrelated changes. 
Second, I test robustness to sample. I include all countries in sample, not only the active ones. This reduces the estimated size of the coefficient on mercantilist motivations, it is still significant (Table 9, column 4). I also exclude Korea from the sample, as its top four trade competitors are countries with reserve currencies (Table 9, column 5). Excluding Korea increases the responsiveness to mercantilism proxy.

\section{Table 9: Robustness Checks: Alternative Measures of Inflow Controls and Broader Sample of Countries}

\begin{tabular}{|c|c|c|c|c|c|}
\hline & \multicolumn{4}{|c|}{ Dependent Variable: Weighted Net Inflow Tightenings (non-FDI) } & \multirow[b]{2}{*}{$\begin{array}{c}\text { Excluding } \\
\text { Korea } \\
(5)\end{array}$} \\
\hline & $\begin{array}{c}\text { Without reducing } \\
\text { ordered categories } \\
\text { (1) }\end{array}$ & $\begin{array}{l}\text { Unweighted } \\
\text { data } \\
\text { (2) }\end{array}$ & $\begin{array}{l}\text { Including FDI- } \\
\text { related changes } \\
\text { (3) }\end{array}$ & $\begin{array}{c}\text { All } \\
\text { countries } \\
(4)\end{array}$ & \\
\hline $\begin{array}{l}\text { Mercantilism Proxy (Country- } \\
\text { Specific) }\end{array}$ & $1.21^{\star *}$ & $1.19^{*}$ & $1.19^{*}$ & $1.17^{\star}$ & $1.25^{\star \star}$ \\
\hline Bank Credit-GDP gap (\%) & $1.24^{\star * *}$ & $1.23^{* * *}$ & $1.21^{* * *}$ & $1.27^{\star * *}$ & $1.23^{* * *}$ \\
\hline Previous policy action (T, E) & $1.37^{* * *}$ & $1.37^{* * *}$ & $1.26^{\star * *}$ & $1.38^{* * *}$ & $1.35^{\star * *}$ \\
\hline Fiscal Stance & 1.11 & 1.09 & $1.13^{* * *}$ & $1.12^{*}$ & $1.13^{*}$ \\
\hline Monetary Stance & $0.90^{*}$ & $0.91^{*}$ & $0.84^{* * *}$ & $0.88^{* *}$ & 0.91 \\
\hline$\Delta$ Reserves/GDP (\%, residuals) & $1.32^{\star * *}$ & $1.31^{* * *}$ & $1.28^{* *}$ & $1.26^{* *}$ & $1.34^{* * *}$ \\
\hline Inflation & 0.95 & 0.94 & 0.96 & $0.91^{*}$ & 0.93 \\
\hline VIX & 0.99 & 0.99 & 1.00 & 0.99 & 0.99 \\
\hline Crisis Dummy & 0.62 & 0.60 & $0.42^{\star \star *}$ & $0.52^{\star *}$ & 0.63 \\
\hline Observations & 8,558 & 8,558 & 7,739 & 14,782 & 7,780 \\
\hline Number of Countries & 11 & 11 & 11 & 19 & 10 \\
\hline Pseudo-Log Likelihood & -3285 & -1752 & -1911 & -2255 & -1703 \\
\hline Chi-Squared (All coefficients $=0$ ) & 557.5 & 152.9 & 1385 & 189.7 & 1762 \\
\hline P-value (Chi-Squared) & 0 & 0 & 0 & 0 & 0 \\
\hline
\end{tabular}

Source: Author's calculations.

Notes: Reported values are proportional odds ratios. Sample period is 2001w1-2015w52. All domestic control variables are one-week lagged. All continuous domestic variables are standardized but centered at 0 , i.e., the variables are divided by their standard deviation but not demeaned. $\triangle$ Reserves/GDP are residuals from regressions in Table 1. Robust standard errors used. ${ }^{* * *} p<0.01,{ }^{* *} p<0.05,{ }^{*} p<0.10$

Third, I assess motivations for net outflow easings (rather than net NKI restricting measures). The mercantilism proxy is significant in these specifications as well (Table 10).

Fourth, I control for structural country-specific factors, including corruption and governance indicators, and capital account openness indicators (Table 11). The baseline results are robust to adding these variables. More open countries and countries with better regulatory quality are more likely to calibrate capital control policies. Accounting for openness, the response to mercantilist motivations is stronger. 
Table 10: Robustness Checks: Motivations Behind use of Net Outflow Easings

\begin{tabular}{lcc} 
& \multicolumn{2}{c}{ Dependent Variable: } \\
& $\begin{array}{c}\text { Weighted Net Outflow Easings } \\
\text { (non-FDI) } \\
(1)\end{array}$ & Weighted Net Outflow Easings \\
& $1.14^{* *}$ & $(2)$ \\
\hline Mercantilism Proxy (Country- & $0.86^{* *}$ & $1.12^{* *}$ \\
Specific) & 1.16 & $0.88^{* *}$ \\
Bank Credit-GDP gap (\%) & 1.03 & $1.18^{*}$ \\
Previous policy action (T, E) & 0.95 & 1.02 \\
Fiscal Stance & 1.11 & 0.98 \\
Monetary Stance & 1.08 & 1.09 \\
$\Delta$ Reserves/GDP (\%) & 1.00 & $1.10^{* *}$ \\
Inflation & 1.73 & 1.00 \\
VIX & & 1.65 \\
Crisis Dummy & 10,114 & 10,114 \\
& 13 & 13 \\
\hline Observations & -1642 & -1782 \\
Number of Countries & 104.2 & 293.7 \\
Pseudo-Log Likelihood & 0 & 0 \\
Chi-Squared (All coefficients =0) & & \\
P-value (Chi-Squared) & & \\
\hline
\end{tabular}

Source: Author's calculations.

Notes: Reported values are proportional odds ratios. Sample period is 2001w1-2015w52. All domestic control variables are one-week lagged. All continuous domestic variables are standardized but centered at 0 , i.e., the variables are divided by their standard deviation but not demeaned. $\triangle$ Reserves/GDP are residuals from regressions in Table 1. Monetary policy stance and fiscal policy stance are variables that take the value +1 if monetary policy is tightened in the previous week (or structural balance improves), -1 for expansionary policies and 0 otherwise. Robust standard errors used. ${ }^{* * *} p<0.01,{ }^{* *} p<0.05,{ }^{*} p<0.10$

Fifth, I run several alternative specifications to explore the role of the domestic policies and of the nominal exchange rate (Table 12). I control for other domestic macroprudential policies, creating a variable that is the total number of domestic macroprudential measures taken (summing up the components from Cerutti et al. (2016), excluding the foreign currency reserves requirement measures, as the latter are already included in the capital controls data). This variable is not significant. I also use actual changes in structural fiscal balance and in the policy rate, instead of variables capturing the stance of these policies. The results for mercantilist and macroprudential proxies are robust to this change. Using nominal exchange rate in the same specification with mercantilism proxy reduces the size of the coefficient on each, but the coefficients on these variables are still significant. I also add an interaction term between mercantilist and macroprudential proxies to test whether the probability of tightening inflow controls increases more when the exchange rate appreciates against trade competitors, if bank credit to GDP gap in the country is high as well. The resulting coefficient on the interaction term is not significant, while the coefficients on the levels of the variables are robust to the addition of the interaction term. 
Table 11: Robustness Checks: Adding Structural Factors

\begin{tabular}{|c|c|c|c|c|c|c|}
\hline \multicolumn{7}{|c|}{ Dependent Variable: Weighted Net Inflow Tightenings (non-FDI) } \\
\hline & (1) & (2) & (3) & (4) & $(5)$ & (6) \\
\hline Mercantilism Proxy (Country-Specific) & $1.21^{* *}$ & $1.20^{* *}$ & $1.21^{* *}$ & $1.21^{* *}$ & $1.27^{* *}$ & $1.23^{*}$ \\
\hline Bank Credit-GDP gap (\%) & $1.24^{* * *}$ & $1.22^{* * *}$ & $1.24^{* * *}$ & $1.23^{* * *}$ & $1.21^{* * *}$ & $1.22^{* * *}$ \\
\hline Previous policy action (T, E) & $1.37^{\star * *}$ & $1.31^{* * *}$ & $1.35^{\star * *}$ & $1.36^{\star * *}$ & $1.39^{* * *}$ & $1.35^{\star \star *}$ \\
\hline Fiscal Stance & 1.12 & $1.13^{*}$ & 1.13 & 1.11 & 1.10 & $1.12^{*}$ \\
\hline Monetary Stance & $0.91^{*}$ & $0.89^{* *}$ & 0.90 & $0.91^{*}$ & 0.90 & $0.88^{\star *}$ \\
\hline$\Delta$ Reserves/GDP (\%, residuals) & $1.32^{* * *}$ & $1.32^{* * *}$ & $1.33^{* * *}$ & $1.32^{* * *}$ & $1.34^{* * *}$ & $1.36^{* * *}$ \\
\hline Inflation & 0.94 & 0.94 & 0.96 & 0.95 & 0.92 & 0.93 \\
\hline VIX & 0.99 & 0.99 & 0.99 & 0.99 & 0.99 & 0.99 \\
\hline Crisis Dummy & 0.62 & 0.61 & 0.61 & 0.63 & 0.67 & 0.77 \\
\hline Government Effectiveness & 1.05 & & & & & \\
\hline Regulatory Quality & & $2.34^{* *}$ & & & & \\
\hline Rule of Law & & & 1.82 & & & \\
\hline Corruption & & & & 1.31 & & \\
\hline Capital Account Restrictions (Fernandez et al. (2015) & & & & & $0.46^{* *}$ & \\
\hline Capital Account Openness (Chinn-Ito, 2006) & & & & & & $3.14^{\star *}$ \\
\hline Observations & 8,558 & 8,558 & 8,558 & 8,558 & 7,425 & 7,997 \\
\hline Number of Countries & 11 & 11 & 11 & 11 & 11 & 11 \\
\hline Pseudo-Log Likelihood & -1835 & -1832 & -1834 & -1835 & -1617 & -1741 \\
\hline Chi-Squared (All coefficients $=0$ ) & 30906 & 370.8 & 623.4 & 36912 & 327.2 & 2699 \\
\hline P-value (Chi-Squared) & 0 & 0 & 0 & 0 & 0 & 0 \\
\hline
\end{tabular}

Source: Author's calculations.

Notes: Reported values are proportional odds ratios. Sample period is 2001w1-2015w52. All domestic control variables are one-week lagged. All continuous domestic variables are standardized but centered at 0 , i.e., the variables are divided by their standard deviation but not demeaned. Monetary policy stance and fiscal policy stance are variables that take the value +1 if monetary policy is tightened in the previous week (or structural balance improves), -1 for expansionary policies and 0 otherwise. $\Delta$ Reserves/GDP are residuals from regressions in Table 1. Robust standard errors used. ${ }^{* *} p<0.01,{ }^{* *} p<0.05,{ }^{*} p<0.10$

Sixth, I use alternative measures of global liquidity instead of VIX, including global bank claims (as percentage of global GDP, from BIS), oil prices and U.S. federal funds shadow rate (Table 13). These modifications do not change the baseline results. In this table, I also use an alternative measure of bank credit to GDP gap, which uses Hamilton (2018) methodology, to overcome to issues with HP-filter. ${ }^{35}$ The results are robust to this specification as well.

Finally, I report the goodness of fit test of out-of-sample forecasts (Table 14). I use the last three years of the sample (2012-2015) as the out-of-sample period. The out-of-sample forecast performance of the models is still good, ranging from $0.62-0.73$ for policy actions.

\footnotetext{
${ }^{35}$ The alternative Bank credit to GDP gap is computed using quarterly data, and then interpolated to weekly. The parameters used are suggested by Hamilton (2018), $\mathrm{p}=4$ and $\mathrm{h}=8$.
} 
Table 12: Robustness Checks: Domestic Policies, Nominal Exchange Rate and Interactions

\begin{tabular}{|c|c|c|c|c|}
\hline & \multicolumn{4}{|c|}{ Dependent Variable: Weighted Net Inflow Tightenings (non-FDI) } \\
\hline & (1) & (2) & (3) & (4) \\
\hline Mercantilism Proxy (Country-Specific) & $1.24^{* *}$ & $1.23^{\star \star}$ & $1.15^{\star \star}$ & $1.20^{*}$ \\
\hline Bank Credit-GDP gap (\%) & $1.21^{* * *}$ & $1.27^{* * *}$ & $1.24^{* * *}$ & $1.23^{* * *}$ \\
\hline Previous policy action (T, E) & $1.35^{* * *}$ & $1.34^{* * *}$ & $1.37^{\star * \star}$ & $1.36^{* * *}$ \\
\hline Fiscal Stance & 1.11 & & 1.10 & $1.12^{*}$ \\
\hline Monetary Stance & $0.87^{* *}$ & & 0.92 & $0.90^{* *}$ \\
\hline Domestic Macroprudential Policies & 1.16 & & & \\
\hline VIX & 0.99 & 0.99 & 0.99 & 0.99 \\
\hline Crisis Dummy & 0.77 & 0.52 & 0.62 & 0.60 \\
\hline$\Delta$ Reserves/GDP (\%, residuals) & $1.33^{* * *}$ & $1.30^{* * *}$ & $1.27^{* * *}$ & $1.31^{* *}$ \\
\hline Inflation & 0.91 & 0.93 & 0.94 & 0.94 \\
\hline$\Delta$ Fiscal balance/GDP (\%) & & $1.09^{*}$ & & \\
\hline$\Delta$ Policy rate $(\%)$ & & $0.95^{\star *}$ & & \\
\hline $\begin{array}{l}\text { Exchange rate vs. USD (Nominal, 13-wk } \\
\text { appr, \%) }\end{array}$ & & & $1.16^{*}$ & \\
\hline Mercantilism Proxy (Country-Specific)*Bank & & & & \\
\hline Credit-GDP gap (\%) & & & & 1.07 \\
\hline Observations & 7,997 & 8,284 & 8,550 & 8,558 \\
\hline Number of Countries & 11 & 11 & 11 & 11 \\
\hline Pseudo-Log Likelihood & -1742 & -1750 & -1826 & -1834 \\
\hline Chi-Squared (All coefficients $=0$ ) & 20012 & 176 & 1892 & 977 \\
\hline P-value (Chi-Squared) & 0 & 0 & 0 & 0 \\
\hline $\begin{array}{l}\text { Source: Author's calculations. } \\
\text { Notes: Reported values are proportional o } \\
\text { variables are one-week lagged. All contin } \\
\text { variables are divided by their standard de } \\
\text { stance are variables that take the value + } \\
\text { balance improves), }-1 \text { for expansionary pc } \\
\text { in Table } 1 \text {. Robust standard errors used. * }\end{array}$ & $\begin{array}{l}\text { os. Sampl } \\
\text { nestic var } \\
\text { ut not der } \\
\text { tary polic } \\
\text { id } 0 \text { other } \\
1,{ }^{* *} p<0 \text {. }\end{array}$ & $\begin{array}{l}2001 \mathrm{w} 1 \\
\text { tandarc } \\
\text { netary } \\
\text { ed in th } \\
\text { erves/G }\end{array}$ & $\begin{array}{l}\text { 2. All d } \\
\text { centere } \\
\text { ince an } \\
\text { s week } \\
\text { esidual }\end{array}$ & $\begin{array}{l}\text { c control } \\
\text { i.e., the } \\
\text { policy } \\
\text { uctural } \\
\text { egression }\end{array}$ \\
\hline
\end{tabular}


Table 13: Robustness Checks: Other Global Variables and Bank Credit Gap

\begin{tabular}{|c|c|c|c|c|}
\hline & \multicolumn{4}{|c|}{$\begin{array}{l}\text { Dependent Variable: Weighted Net Inflow Tightenings } \\
\text { (non-FDI) }\end{array}$} \\
\hline & $(1)$ & (2) & (3) & (4) \\
\hline Mercantilism Proxy (Country-Specific) & $1.21^{* *}$ & $1.21^{* *}$ & $1.20^{* *}$ & $1.24^{* *}$ \\
\hline Bank Credit-GDP gap (\%) & $1.22^{* * *}$ & $1.25^{\star * *}$ & $1.25^{\star * *}$ & \\
\hline Previous policy action (T, E) & $1.36^{\star * *}$ & $1.36^{* * *}$ & $1.37^{* * *}$ & $1.34^{* * *}$ \\
\hline Fiscal Stance & $1.13^{*}$ & $1.13^{*}$ & $1.12^{*}$ & $1.13^{*}$ \\
\hline Monetary Stance & 0.92 & 0.92 & 0.93 & $0.90^{*}$ \\
\hline$\Delta$ Reserves/GDP (\%, residuals) & $1.34^{* * *}$ & $1.36^{* * *}$ & $1.34^{* * *}$ & $1.36^{\star * *}$ \\
\hline Inflation & 0.93 & 0.94 & 0.95 & 0.94 \\
\hline Crisis Dummy & $0.53^{* \star *}$ & $0.53^{* * *}$ & $0.48^{* * *}$ & $0.58^{*}$ \\
\hline Federal Funds Shadow Rate (\%) & 0.99 & & & \\
\hline World Bank Claims (\% of GDP) & & 0.99 & & \\
\hline Oil Prices & & & $1.00^{*}$ & \\
\hline Bank Credit-GDP gap (\%, Hamilton, 2018 methodology) & & & & $1.22^{* * *}$ \\
\hline VIX & & & & 1.00 \\
\hline Observations & 8,558 & 8,558 & 8,558 & 8,521 \\
\hline Number of Countries & 11 & 11 & 11 & 11 \\
\hline Pseudo-Log Likelihood & -1836 & -1836 & -1835 & -1836 \\
\hline Chi-Squared (All coefficients $=0$ ) & 144.7 & 644.6 & 146.6 & 2443 \\
\hline P-value (Chi-Squared) & 0 & 0 & 0 & 0 \\
\hline
\end{tabular}

Source: Author's calculations.

Notes: Reported values are proportional odds ratios. Sample period is 2001w1-2015w52. All domestic control variables are one-week lagged. All continuous domestic variables are standardized but centered at 0 , i.e., the variables are divided by their standard deviation but not demeaned. Monetary policy stance and fiscal policy stance are variables that take the value +1 if monetary policy is tightened in the previous week (or structural balance improves), -1 for expansionary policies and 0 otherwise. $\triangle$ Reserves/GDP are residuals from regressions in Table 1. Robust standard errors used. ${ }^{* * *} p<0.01,{ }^{* *} p<0.05,{ }^{*} p<0.10$

Table 14: Robustness Checks: Out-of-Sample Forecasts

Dependent variable: Weighted Net Inflow Tightenings (non-FDI)

\begin{tabular}{rrrrrr}
\hline \multicolumn{1}{c}{ Outcome } & $\mathrm{N}$ & AUROC & Std. Err. & [95\% Conf. Interval] \\
\hline-1 & 2288 & 0.7 & 0.05 & 0.59 & 0.81 \\
-0.5 & 2288 & 0.64 & 0.03 & 0.57 & 0.7 \\
0 & 2288 & 0.48 & 0.03 & 0.43 & 0.54 \\
0.5 & 2288 & 0.63 & 0.07 & 0.5 & 0.76 \\
1 & 2288 & 0.69 & 0.08 & 0.53 & 0.84 \\
\hline
\end{tabular}

Source: Author's calculations.

Note: In-sample period is 2001w1-2011w52, and out-of-sample period is 2012w1-2015w52. Each model is panel logit, with dependent variable redefined to be a dichotomous variable. For example, in the first block of models, the dependent variable takes value 1 when the ordered (weighted, non-FDI) net inflow tightening variable $=-1$, and 0 otherwise. 


\section{CONCLUSIONS}

Are capital controls macroprudential or mercantilist? The results in this paper strongly suggest that they are both. The results provide clear evidence that capital controls policy in emerging markets has been systematic, and that it has responded to both macroprudential and mercantilist motivations. The use of net inflow tightening measures can be described by a function of mercantilist and macroprudential motivations. Moreover, the choice of instruments is also systematic: policymakers respond to mercantilist concerns by using both instruments - inflow tightening and outflow easing. However, they use only inflow tightening in response to macroprudential concerns. This is the first paper to provide evidence of the existence of a macroprudential motivation in the use of capital controls policy, even before these controls were generally acknowledged after the global financial crisis, as valid tools of the macroprudential policy toolkit. Yet, the analysis in this paper underlines that the concerns of those who worry about a currency war are also justifiedcapital controls have also been systematically used to preserve competitive advantage in trade.

These results highlight an assignment problem of using one tool (inflow controls) to meet multiple objectives (Tinbergen, 1962). They suggest a need for further debate on whether it would be globally optimal if countries used capital control actions solely as a tool of macroprudential policies, and if so, how to ensure that this is the case.

The results also suggest that capital controls have not been targeted specifically to foreign-toforeign currency debt-inflow controls are not countercyclical to the specific macroprudential concerns related to external or foreign currency borrowing. Rather, policy appears acyclical to these variables, but is countercyclical to domestic bank credit to the private non-financial sector. The tightening of controls on foreign credit when domestic credit is booming may simply reflect that regulators find it easier to target foreign credit than domestic credit, either because of lack of adequate domestic prudential tools or because of shortcomings of domestic institutional frameworks. As capital controls become more widely used as tools of macroprudential policies, future research and policy discussions could focus on how best to ensure that these instruments are targeted directly to the vulnerabilities they seek to address. 


\section{REFERENCES}

Acharya, S. and Bengui, J. (2018) "Liquidity traps, capital flows" Journal of International Economics, Volume 114, September 2018, Pages 276-298

Adrian, T. (2018) "Policy Responses to Capital Flows" Remarks at the LIII Meeting of Governors of Latin America, Spain and the Philippines at the IMF-World Bank Annual Meetings in Bali, Indonesia, 11 October 2018.

Agénor, Pierre-Richard and Pengfei Jia (2015) "Capital Controls and Welfare with CrossBorder Bank Capital Flows," Centre for Growth and Business Cycle Research Discussion Paper Series 212, Economics, The University of Manchester.

Aizenman, J and J Lee (2007) "International reserves: precautionary versus mercantilist views, theory and evidence", Open Economies Review, vol. 18, no. 2, pp 191-214.

Aizenman, J and G Pasricha (2013) "Why do emerging markets liberalize capital outflow controls? Fiscal versus net capital flow concerns", Journal of International Money and Finance, vol. 39, pp 28-64.

Alfaro, L, A Chari and F Kanczuk (2017) "The real effects of capital control taxes: firm-level evidence from a policy experiment", Journal of International Economics 108 (September 2017): 191-210.

Avdjiev, S, L Gambacorta, L Goldberg and S Schiaffi (2017) "The shifting drivers of global liquidity”, Bank for International Settlements, Working paper no. 644, June.

Benigno, G, C Huigang, C Otrok, A Rebucci and E Young (2011) "Monetary and macroprudential policies: an integrated analysis", $12^{\text {th }}$ Jacques Polak Annual Research Conference, International Monetary Fund, mimeo.

Bernanke, B.S. (2015) "Federal Reserve Policy in an International Context," Paper presented at $16^{\text {th }}$ Jacques Polak Annual Research Conference, November 5-6, 2015.

Bhalla, S.S. (2012) "Devaluing to Prosperity: Misaligned Currencies and Their Growth Consequences" Peterson Institute for International Economics, August 2012

Bianchi, J (2011) "Overborrowing and systemic externalities in the business cycle”, American Economic Review, vol. 101, no. 7, pp 3400-26.

Bianchi, J., and Mendoza, E.G. (2016). “Optimal Time-Consistent Macroprudential Policy," forthcoming, Journal of Political Economy, http://www.sas.upenn.edu/ egme/wp/w19704.pdf .

BIS-FSB-IMF (2011) "Macroprudential policy tools and frameworks", Progress Report to G20.

Bussière, M, G Gaulier and W Steingress (2016) "Global trade flows: revisiting the exchange rate elasticities”, Banque de France Working Papers, no. 608, Banque de France.

Carney, M. (2019) "Pull, Push, Pipes: Sustainable Capital Flows for a New World Order" Speech given by Mark Carney, Governor of the Bank of England to Institute of International Finance Spring Membership Meeting, Tokyo, 6 June 2019. 
Casas, C, F Diez, G Gopinath and P Gourinchas (2016) "Dominant currency paradigm", NBER Working Paper Series, no. 22943, December.

Cerutti, E, R Correa, E Fiorentino and E Segalla (2016) “Changes in prudential policy instruments: a new cross-country database”, IMF Working Papers, no. 16, June.

Cheung, Y and X Qian (2009) "Empirics of China's outward direct investment", HKIMR Working Papers, no. 17, May.

Choi, Woo Jin \& Taylor, Alan M., 2017. "Precaution Versus Mercantilism: Reserve Accumulation, Capital Controls, and the Real Exchange Rate," CEPR Discussion Papers 11963, C.E.P.R. Discussion Papers.

Costinot, A, G Lorenzoni and I Werning (2014) "A theory of capital controls as dynamic terms-of-trade manipulation", Journal of Political Economy, vol. 122, no. 1, pp 77-128.

Davis, J.S. and Devereux, M.B. (2019) "Capital Controls as Macro-prudential Policy in a Large Open Economy” NBER Working Paper No. 25710, March 2019.

Devereux, Michael B., and James Yetman (2014) "Capital Controls, Global Liquidity Traps, and the International Policy Dilemma," Scandinavian Journal of Economics, 116 (March 2014), 158-89

Devereux, Michael B., and ChanghuaYu (2019) "Evaluating the role of capital controls and monetary policy in emerging market crises" Journal of International Money and Finance, Volume 95, July 2019, Pages 189-211

Dooley, M, D Folkerts-Landau and P Garber (2003) "The revived Bretton Woods system", International Journal of Finance and Economics, vol. 9, no. 4, pp 307-13.

Dooley, M, D Folkerts-Landau and P Garber (2014) "The revived Bretton Woods system", NBER Working Paper Series, no. 20454, September.

Durdu, C. Bora, Mendoza, Enrique and Terrones, Marco, (2009), Precautionary demand for foreign assets in Sudden Stop economies: An assessment of the New Mercantilism, Journal of Development Economics, 89, issue 2, p. 194-209, https://EconPapers.repec.org/RePEc:eee:deveco:v:89:y:2009:i:2:p:194-209.

Fernández, A, M Klein, A Rebucci, M Schindler and M Uribe (2015a) "Capital control measures: a new dataset”, IMF Working Papers, no. 80, April.

Fernández, A, A Rebucci, M Schindler and M Uribe (2015b) “Are capital controls countercyclical?” Journal of Monetary Economics, vol. 76, pp 1-14.

Forbes, K, M Fratzscher and R Straub (2015) "Capital-flow management measures: what are they good for?” Journal of International Economics, vol. 96, no. S1, pp S76-S97.

Forbes, K, M Fratzscher, T Kostka and R Straub (2016) "Bubble thy neighbour: portfolio effects and externalities from capital controls", Journal of International Economics, vol. 99, pp 85-104.

Fratzscher, M (2014) “Capital controls and foreign exchange policy” in: Fuentes, M, C Raddatz and C Reinhart (eds), Capital Mobility and Monetary Policy. Santiago, Chile: Central Bank of Chile. 
G20 (2011) "G20 Coherent Conclusions for the Management of Capital Flows Drawing on Country Experiences", as endorsed by G20 Finance Ministers and Central Bank Governors, 15 October 2011.

Ghosh, A, J Ostry and C Tsangarides (2012) "Shifting motives: explaining the buildup in official reserves in emerging markets since the 1980s", IMF Working Papers, no. 34, January.

Hamilton, J.D. (2018) "Why you should never use the Hodrick-Prescott Filter", The Review of Economics and Statistics, vol 100(5), pages 831-843.

Hamilton, J and O Jorda (2002) "A model of the federal funds rate target", Journal of Political Economy, vol. 110, no. 5, pp 1135-67.

Heathcote, J and F Perri (2016) "On the desirability of capital controls," IMF Economic Review, vol. 64, no. 1, pp 75-102.

Hemrit, M (2013) 'Pecking order macro-prudential tools: BOT's experience from tailored policy measures to Basel III's countercyclical buffer", Chapter 11, Basel III Implementation: Challenges and Opportunities, Kuala Lumpur: South East Asian Central Banks.

IDB (2016) "2016 Latin American and Caribbean macroeconomic report: Time to act: Latin America and the Caribbean facing strong challenges", Inter-American Development Bank, April.

IMF (2012) “The Liberalization and Management of Capital Flows: An Institutional View”, International Monetary fund, November 14, 2012.

Jeanne, $\mathrm{O}$ and A Korinek (2010) "Excessive volatility in capital flows: a Pigouvian taxation approach”, American Economic Review, vol. 100, no. 2, pp 403-07.

Jeanne, O and R Ranciere (2006) "The optimal level of international reserves for emerging market countries: formulas and applications”, IMF Working Papers, no. 229, October.

Jorda, O, M Schularick and A Taylor (2012) "When credit bites back: leverage, business cycles, and crises", Federal Reserve Bank of San Francisco Working Paper Series, no. 201127, October.

Korinek, A (2010) "Regulating capital flows to emerging markets: an externality view", (May). SSRN: https://ssrn.com/abstract=1330897 or http://dx.doi.org/10.2139/ssrn.1330897

Korinek, A (2011) "The new economics of prudential capital controls: a research agenda", IMF Economic Review, vol. 59, no. 3, pp 523-61.

Korinek, A (2016) "Currency wars or efficient spillovers? A general theory of international policy cooperation”, NBER Working Papers, no. 23004, December.

Korinek, A and D Sandri (2016) “Capital controls or macroprudential regulation?" Journal of International Economics, vol. 99, no. S1, pp S27-S42.

Ljungqvist, L and T.J. Sargent (2004) Recursive Macroeconomic Theory, 2nd edition, Boston: MIT Press. 
Mendoza, E (2002) "Credit, prices, and crashes: business cycles with a sudden stop", in: Edwards, S and J Frankel (eds), Preventing Currency Crises in Emerging Markets, Chicago: University of Chicago Press.

Monokroussoss, G (2011) "Dynamic limited dependent variable modelling and U.S. monetary policy”, Journal of Money, Credit and Banking, vol. 43, pp 519-34.

Ostry, J.D., M Chamon, A.R. Ghosh and M.S. Qureshi (2011) "Capital controls: when and why?" IMF Economic Review, vol. 59, no. 3, pp 562-80.

Ostry, J.D., M Chamon, A.R. Ghosh and M.S. Qureshi (2012) "Tools for managing financialstability risks from capital inflows", Journal of International Economics, vol. 88, no. 2, pp 407-21.

Pasricha, G, M Falagiarda, M Bijsterbosch and J Aizenman (2018) "Domestic and multilateral effects of capital controls in emerging markets", Journal of International Economics, vol. 115, pp 48-58, November.

Patel, N., Wang, Z. and S. Wei (2017) "Global value chains and effective exchange rates at the country-sector level” BIS Working Paper No. 637, May 2017.

Ramey, V (2016) "Macroeconomic shocks and their propagation", NBER Working Paper Series, no. 21978, February.

Riyanto, E (2016) “Unveiling macroprudential policy”, Speech by Deputy Governor: $10^{\text {th }}$ International Conference on Bulletin of Monetary Economics and Banking, Bank Indonesia.

Schmitt-Grohé, S and M Uribe (2016a) "Is optimal capital-control policy countercyclical in open-economy models with collateral constraints?" NBER Working Paper Series, no. 22481, August.

Schmitt-Grohé, S and M Uribe (2016b) “Downward Nominal Wage Rigidity, Currency Pegs, and Involuntary Unemployment”, Journal of Political Economy 124, October 2016, 14661514.

Schularick, M and A.M. Taylor (2012) "Credit booms gone bust: monetary policy, leverage cycles, and financial crises, 1870-2008”, American Economic Review, vol. 102, no. 2, 102961.

Shambaugh, J.C. (2004) "The effect of fixed exchange rates on monetary policy", Quarterly Journal of Economics, vol. 119, no. 1, pp 301-52.

Silva, P.G. (2016) “Chile's experience in macroprudential policy and institutional governance", Central Bank of Chile, mimeo.

Taylor, J (1993) "Discretion versus policy rules in practice", Carnegie-Rochester Conference Series on Public Policy, 39, pp 195-214.

Tinbergen, J (1962) Shaping the world economy: Suggestions for an international economic policy, New York: Twentieth Century Fund.

Uribe, M (2007) "On overborrowing”, American Economic Review Papers and Proceedings, vol. 96, pp 417-21. 
Weigel, A, M Liniger and C Appenzeller (2007) "The discrete brier and ranked probability skill scores”. Federal Office of Meteorology and Climatology (MeteoSwiss). 


\section{Appendix A: Stylized FaCts on EXChange RATe ANd CREDit CyCleS}

Most of the recent literature on macroprudential capital controls is framed in a way that suggests that macroprudential and mercantilist objectives would require the same directional policy response to exchange rate changes. ${ }^{36}$ That is, much of this literature assumes that the exchange rate cycle and the financial cycle in emerging economies is highly synchronized, and a policy of mitigating exchange rate changes would also mitigate the credit cycle. This section lays out some stylized facts based on the unconditional correlations between the real effective exchange rate, external and domestic bank credit, and finds that these cycles are not fully synchronized in the data. This implies that the mercantilist and macroprudential motivations in practice do involve trade-offs.

The exchange rate and credit cycle are illustrated for the case of Korea in Figure 1A below. When the real exchange rate is appreciating but credit cycle is in downturn or repair, as happened after 2012Q3, tighter capital inflow controls could further reduce credit availability in the domestic economy and curtail economic growth. On the other hand, looser inflow controls to boost credit growth could lead to a further appreciation of the currency and hurt exporting and import-competing sectors. Stabilizing the exchange rate therefore would not be the same as stabilizing the credit cycle- the mercantilist and macroprudential responses could require different directional responses via capital controls.

Figure A1: Korea: REER Appreciation and Bank Credit to GDP Gap

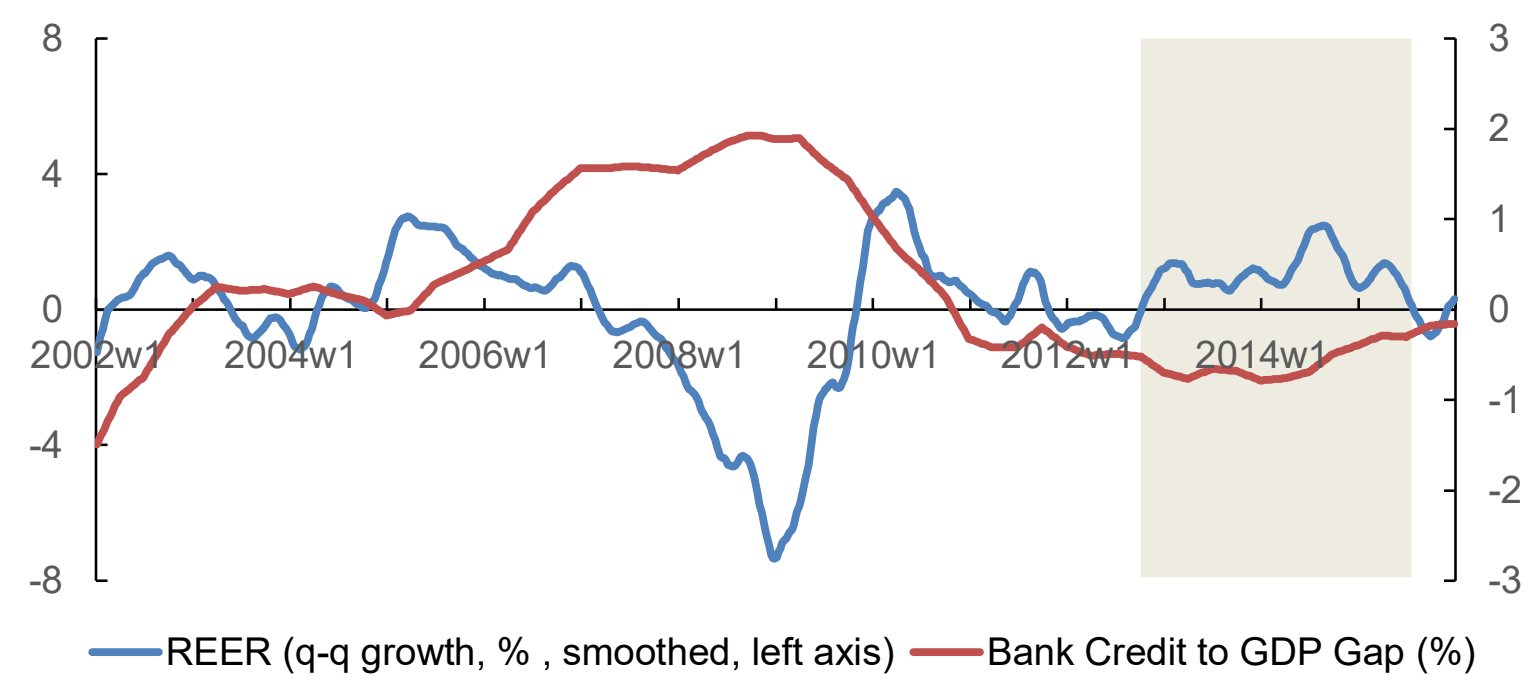

Source: Haver, BIS, and author's calculations.

Notes: REER growth is computed over previous 13 weeks, and smoothed using a 5-week backward looking moving average.

Last observation: 2015w54

\footnotetext{
36 Two important exceptions are Choi and Taylor (2017) and Davis and Devereux (2019) which explicitly model both precautionary and mercantilist motivations. Choi and Taylor (2017), show the potential for tradeoffs between the two motivations and also show how the optimal mix of capital controls and reserves accumulation policies is jointly determined. Davis and Devereux (2019) model the desire for a large open economy to manipulate terms of trade through inflow taxes and to tax outflows for prudential or crisis management purposes.
} 
I systematically examine these trade-offs and document three findings: first, the real effective exchange rate (REER) and external credit gap are negatively correlated for may emerging economies and time periods. Second, the external and domestic bank credit gap are negatively correlated for many emerging economies and time periods. Finally, domestic bank credit to GDP gap and REER have a positive correlation for the largest number of countries in sample, suggesting channels other than direct foreign lending expansion are in operation, but even here, the correlation between the two series is negative for some countries and subperiods.

Table A1: Correlations: Real Effective Exchange Rate and External Credit Gap

\begin{tabular}{|c|c|c|c|c|}
\hline & $2001-2015$ & $2001-2005$ & $2006-2010$ & $2011-2015$ \\
\hline ARG & $0.41^{\star * \star}$ & $-0.40^{* \star \star}$ & $0.57^{* * \star}$ & $-0.28^{* \star \star}$ \\
\hline BRA & $-0.67^{* * *}$ & $-0.74^{* * *}$ & $0.13^{*}$ & $-0.84^{* * *}$ \\
\hline $\mathrm{CHL}$ & $-0.70^{* * *}$ & $-0.67^{* * *}$ & $0.37^{* * *}$ & $-0.84^{* * *}$ \\
\hline $\mathrm{CHN}$ & $0.74^{* * *}$ & $-0.16^{\star *}$ & $0.53^{* * *}$ & $0.73^{\star * *}$ \\
\hline $\mathrm{COL}$ & $-0.56^{* * *}$ & $-0.30^{* * *}$ & $-0.42^{* * *}$ & $-0.83^{\star \star *}$ \\
\hline CZE & $0.58^{* \star *}$ & $0.59^{* * *}$ & $0.75^{\star * \star}$ & $-0.25^{\star \star \star}$ \\
\hline HUN & $0.53^{* \star *}$ & $0.50^{\star \star \star}$ & 0.12 & $0.82^{\star \star \star}$ \\
\hline IDN & $0.70^{\star \star \star}$ & $-0.59^{* * *}$ & $0.82^{* \star *}$ & 0.12 \\
\hline IND & $-0.16^{* * *}$ & -0.09 & $-0.32^{* * *}$ & 0.05 \\
\hline KOR & $-0.82^{* * *}$ & $-0.40^{* * *}$ & $-0.94^{\star * *}$ & $-0.87^{\star * *}$ \\
\hline MEX & $-0.70^{* * *}$ & $0.54^{\star * *}$ & $-0.79^{\star \star *}$ & $-0.17^{* *}$ \\
\hline MYS & $-0.52^{* * *}$ & $0.52^{* * *}$ & $-0.43^{* * *}$ & $-0.70^{* * *}$ \\
\hline PER & $0.54^{* \star *}$ & $0.79^{\star * *}$ & $0.71^{* * *}$ & $0.54^{* * *}$ \\
\hline PHL & $-0.36^{* * *}$ & $-0.26^{* * *}$ & $0.35^{\star * \star}$ & $-0.54^{* * *}$ \\
\hline POL & $0.18^{\star * *}$ & $-0.36^{\star * *}$ & $-0.34^{* * *}$ & $0.46^{* \star *}$ \\
\hline RUS & $-0.52^{* * *}$ & $-0.89^{* * *}$ & $-0.30^{* * *}$ & $-0.55^{* \star *}$ \\
\hline THA & $0.86^{\star \star \star}$ & $-0.75^{\star \star *}$ & $0.60^{\star \star *}$ & $0.49^{\star \star \star}$ \\
\hline TUR & $-0.37^{\star * *}$ & $-0.61^{* * *}$ & -0.01 & $-0.37^{\star * *}$ \\
\hline ZAF & $-0.77^{\star * *}$ & $-0.82^{\star * *}$ & $-0.60^{\star \star *}$ & $-0.88^{* * *}$ \\
\hline
\end{tabular}

Source: Author's calculations.

Note: The table shows the unconditional correlations between real effective exchange rate (REER) and external credit gap for 19 emerging economies, for 2001-2015 and its various sub-periods. Country abbreviations are ISO codes. Real effective exchange rate is the JP Morgan broad index, with 2010=100. Increases in REER imply appreciation of the currency. External credit gap is the deviation of external credit from its lagged 10-year moving average. External credit is the sum of stock of liabilities to BIS reporting banks (locational banking statistics) and the outstanding stock of international debt securities (from BIS International Debt Securities Database). Data used are weekly, but results are robust to using quarterly data. Highlighted cells are those where the correlations are negative and significant. ${ }^{* * *} p<0.01,{ }^{* *} p<0.05,{ }^{*} p<0.10$

Table A1 shows the unconditional correlations between the real effective exchange rate (REER) and the external credit gap for 19 emerging economies, for the period 2001-2015 and its various sub-periods. The recent models for macroprudential capital controls assume that this correlation is positive, i.e., REER appreciates when external credit is booming. While this story was true for many emerging markets during the 2006-2010 period, it does not universally hold, even in that sub-period. The correlation between real exchange rate and external credit gap was positive only for eight economies for the full sample period 20012015. For 14 countries, the correlation was positive in at least one sub-period, but for 5 
countries, it was always negative. Assuming away inflation differentials, the negative correlation can arise if net capital inflows are high not because gross inflows are high but because gross outflows by residents are low. It can also arise if much of gross inflows are in the form of equity-based flows. This table suggests that the two objectives of capital controls policy may involve trade-offs.

\section{Table A2: Correlations: External Credit Gap and Bank Credit Gap}

\begin{tabular}{|c|c|c|c|c|}
\hline & $2001-2015$ & $2001-2005$ & $2006-2010$ & $2011-2015$ \\
\hline ARG & $-0.97^{\star \star *}$ & $-0.94^{* * *}$ & $-0.36^{* \star *}$ & $-0.85^{* \star *}$ \\
\hline BRA & $-0.83^{* \star *}$ & -0.06 & $-0.51^{* * *}$ & $-0.94^{* * *}$ \\
\hline $\mathrm{CHL}$ & $-0.39^{\star * *}$ & $-0.22^{* * *}$ & $0.15^{*}$ & $0.39^{* \star *}$ \\
\hline $\mathrm{CHN}$ & $0.42^{* * *}$ & $-0.87^{\star \star *}$ & -0.12 & $0.62^{* \star *}$ \\
\hline COL & $-0.73^{* * *}$ & $-0.68^{* * *}$ & $0.35^{\star * *}$ & $-0.58^{* * *}$ \\
\hline CZE & $-0.17^{\star \star \star}$ & $0.86^{\star * *}$ & $-0.42^{* \star *}$ & $-0.37^{\star * *}$ \\
\hline HUN & $0.52^{\star \star \star}$ & $0.74^{\star * *}$ & $-0.30^{\star \star *}$ & $0.87^{\star \star \star}$ \\
\hline IDN & $-0.75^{\star * *}$ & $-0.97^{\star * *}$ & $-0.92^{* * *}$ & $-0.69^{* * *}$ \\
\hline IND & $-0.11^{* *}$ & 0.03 & $-0.69^{* * *}$ & $0.58^{* * *}$ \\
\hline KOR & $0.31^{* * *}$ & $-0.91^{* * *}$ & 0.12 & 0.1 \\
\hline MEX & $-0.82^{\star \star *}$ & $-0.83^{\star * \star}$ & $-0.88^{* * *}$ & $-0.94^{* * *}$ \\
\hline MYS & $-0.58^{\star * *}$ & $0.57^{\star \star *}$ & $-0.84^{* \star *}$ & $-0.72^{* * *}$ \\
\hline PER & $0.30^{\star \star \star}$ & $-0.58^{* * *}$ & $0.68^{\star \star \star}$ & -0.12 \\
\hline PHL & $-0.92^{* * *}$ & $-0.49^{* * *}$ & $-0.94^{* * *}$ & $0.57^{* * *}$ \\
\hline POL & $0.66^{\star * *}$ & $-0.87^{\star \star *}$ & $0.47^{\star * *}$ & $0.75^{\star \star \star}$ \\
\hline RUS & $-0.16^{\star \star \star}$ & $-0.56^{\star \star *}$ & $-0.45^{\star \star *}$ & $0.92^{\star \star \star}$ \\
\hline THA & $0.49^{\star \star \star}$ & $-0.98^{* * *}$ & $0.72^{\star \star \star}$ & $-0.64^{* * *}$ \\
\hline TUR & $-0.36^{\star \star *}$ & $-0.90^{* \star *}$ & $-0.76^{* * *}$ & $-0.77^{\star * *}$ \\
\hline ZAF & $-0.29^{\star * *}$ & $-0.76^{\star * \star}$ & $-0.30^{* * *}$ & $0.97^{\star \star \star}$ \\
\hline
\end{tabular}

Source: Author's calculations.

Note: Country abbreviations are ISO codes. External credit gap is the deviation of external credit to GDP from its lagged 10-year moving average. External credit is the sum of stock of liabilities to BIS reporting banks (locational banking statistics) and the outstanding stock of international debt securities (from BIS International Debt Securities Database). Bank credit gap is the deviation of domestic bank credit to private non-financial sector as a share of GDP from its lagged 10-year moving average. Data used are weekly, but results are robust to using quarterly data. ${ }^{* *} p<0.01,{ }^{* *} p<0.05,{ }^{*} p<0.10$

Table A2 shows the unconditional correlations between the external credit gap and the domestic bank credit gap. If the domestic credit cycle was driven by external credit, macroprudential measures that stabilized external credit would also stabilize domestic credit. The table shows that the correlation between domestic and external credit gaps is negative for several countries and sub-periods, sometime strongly negative, and as high as -0.98 . This suggests that external credit could be a substitute for, rather than a complement to domestic bank credit, and stabilizing the two could potentially involve different macroprudential policy responses.

External credit measures used here may not capture the full extent of foreign money fueling domestic banking credit boom. For example, the measure doesn't include foreign portfolio investment into domestically listed securities, which can increase domestic bank credit 
through the non-core funding channel (Adrian, 2018). Therefore, I look at the correlations between REER and domestic bank credit to GDP gap (Table A3). These provide the strongest evidence of synchronicity between real exchange rate and domestic credit boom, as these correlations are positive and significant for 15 out of 21 countries for the full sample. However, even here, the correlations are negative and significant for several countries in the different sub-periods.

Table A3: Correlations: REER and Bank Credit Gap

\begin{tabular}{|c|c|c|c|c|}
\hline & $2001-2015$ & $2001-2005$ & $2006-2010$ & $2011-2015$ \\
\hline ARG & $-0.46^{* \star *}$ & $0.32^{* * *}$ & $-0.28^{* * *}$ & $0.26^{* * *}$ \\
\hline BRA & $0.62^{* * *}$ & -0.00 & $0.38^{* * *}$ & $0.75^{\star \star *}$ \\
\hline $\mathrm{CHL}$ & $0.54^{\star \star \star}$ & -0.07 & $0.51^{* \star *}$ & -0.06 \\
\hline $\mathrm{CHN}$ & $0.56^{\star \star *}$ & $-0.17^{\star *}$ & $0.61^{\star * *}$ & $0.70^{\star \star *}$ \\
\hline $\mathrm{COL}$ & $0.24^{* * *}$ & $-0.34^{* * *}$ & $-0.50^{* * *}$ & $0.13^{*}$ \\
\hline CZE & $0.58^{* * *}$ & $0.66^{* * *}$ & 0.05 & $0.94^{* * *}$ \\
\hline HUN & $0.77^{\star \star *}$ & $0.34^{* * *}$ & $-0.30^{* * *}$ & $0.59^{* * *}$ \\
\hline IDN & $-0.31^{* \star *}$ & $0.49^{* * *}$ & $-0.81^{* * *}$ & $-0.49^{* * *}$ \\
\hline IND & $0.14^{* * *}$ & -0.11 & $-0.20^{* *}$ & 0.02 \\
\hline KOR & 0.07 & $0.52^{\star * *}$ & $-0.16^{*}$ & -0.04 \\
\hline MEX & $0.29^{* * *}$ & $-0.73^{* \star *}$ & $0.62^{* * *}$ & 0.02 \\
\hline MYS & $0.47^{\star * *}$ & $0.51^{* * *}$ & $0.13^{*}$ & $0.52^{* * *}$ \\
\hline PER & $-0.31^{* * *}$ & $-0.56^{\star \star *}$ & $0.51^{* * *}$ & -0.10 \\
\hline PHL & 0.06 & $-0.28^{* * *}$ & $-0.38^{* * *}$ & -0.12 \\
\hline POL & $0.38^{* * *}$ & $0.25^{* * *}$ & -0.09 & $0.24^{* * *}$ \\
\hline RUS & $-0.28^{\star \star \star}$ & $0.34^{* * *}$ & $0.21^{* * *}$ & $-0.63^{* * *}$ \\
\hline THA & $0.72^{\star * *}$ & $0.82^{* * *}$ & 0.05 & $-0.55^{\star \star *}$ \\
\hline TUR & $0.66^{\star * *}$ & $0.52^{* * *}$ & $0.18^{* *}$ & 0.01 \\
\hline ZAF & $0.13^{\star * *}$ & $0.56^{* * *}$ & $-0.25^{\star * *}$ & $-0.78^{* * *}$ \\
\hline
\end{tabular}

Source: Author's calculations.

Note: Country abbreviations are ISO codes. Bank credit gap is the deviation of domestic bank credit to private non-financial sector as a share of GDP from its lagged 10-year moving average. Data used are weekly, but results are robust to using quarterly data. ${ }^{* * *} p<0.01,{ }^{* *} p<0.05,{ }^{*} p<0.10$

\section{Appendix B: Measuring Capital Control Actions}

The dataset used in the paper is an updated version of the Pasricha et al. (2018) indices on capital control policy actions for 21 EMEs, and covers the period 1 January 2001 to 31 December $2015 .{ }^{37}$ This dataset uses a narrative approach: reading the text of the policy changes or descriptions of such changes in other sources and converting them into numerical measures that capture the direction of policy. Policy announcements often contain changes

\footnotetext{
${ }^{37}$ A detailed description of the dataset and the dataset itself are available online as an appendix to the Pasricha et al. (2018): http://www.nber.org/papers/w20822/. Please also see this appendix for a comparison of weighted and unweighted datasets.
} 
on multiple regulatory instruments. These are split and counted separately. A policy "change" or "action" in the dataset has a unique classification along six dimensions:

1. Direction of flow: Resident liabilities (inflows), Resident assets (outflows) or undefined

2. Policy stance: Easing or Tightening

3. Discrimination by residency or currency: Capital Control or Currency-based?

4. Type of instrument: (Micro-) Prudential Type or not

5. Type of Instrument: Quantitative/Price-based/Monitoring

6. International Investment Position (IIP) Category: Foreign Direct Investment [FDI], Portfolio Investment, Other investment or Financial Derivatives

The policy actions so identified are then aggregated by counting the number of actions of each type, to compute measures of policy direction. These aggregations can take place counting each policy action as 1 (unweighted dataset), or after applying weights to each policy action, to better capture the intensive margin of the change (weighted dataset). In the weighted version of the Pasricha et al. (2018) dataset, each action is weighted by the share of the external assets (liabilities) of its IIP category in the total external assets (liabilities) of the country. Further, there are two versions of the weighted dataset: one that counts all actions, and the other that counts only non-FDI actions. The second version is used in the baseline models in this paper because it allows us to focus on actions that reflect macroeconomic or macroprudential concerns with capital flows, i.e., those focused on "hot flows." In this version, which counts only the non-FDI related changes, the weights assigned are the relevant IIP category of the change divided by the total of the non-FDI categories (i.e., Portfolio Investment, Financial Derivatives, and Other Investment). This ensures that even for countries for which FDI is the largest category, policy actions that affect all "hot flows" are given the same weight (of 1) as similar actions by countries where FDI is a small share of the balance sheet.

Most policy actions in the dataset, about 76 percent, are easing actions, roughly equally distributed on the inflow and outflow sides (Table B1). I compute three variables that reflect the net direction of policy in a week, following Pasricha et al. (2018). The first variable is the weighted net inflow tightening measures (number of weighted inflow tightening less easing actions per week). The second variable is the weighted net outflow easing actions, used as a control variable as policymakers can also use outflow easings to lean against net capital inflows. Finally, the sum of the two policy variables is the "weighted net NKI restricting measures," which captures the overall direction of policy, i.e., on the net, the number of weighted measures on the inflow and outflow sides, which have the expected impact of reducing NKI. Note that to compute the net inflow and net outflow actions, I include the measures that are not specific to inflows or outflows (last two columns of Table B1) as both inflow and outflow actions.

There are three main differences in the aggregation methods between the data used in this paper and the Pasricha et al. (2018) dataset. First, in this paper, I use the announcement dates of the changes, rather than their effective dates. Second, I drop changes that were pre- 
announced by more than 60 days, as changes that have more than a 60 -day implementation lag are likely to be more structural in nature, rather than imposed for macroeconomic and macroprudential management. Third, as noted above, in this paper I include changes that potentially affect both inflows and outflows (e.g., currency-based measures) on both the inflow and outflow sides. That is, these changes are counted twice.

The data are sourced from the text sections of the IMF Annual Report on Exchange Arrangements and Exchange Restrictions (AREAER), from the press releases, circulars and notifications on the regulators' and finance ministries' websites, Organization for Economic Co-operation and Development (OECD) reports, news sources as well as other research papers.

Table B1: Policy Actions by Type

\begin{tabular}{lcccccc}
\hline & $\begin{array}{c}\text { Inflow } \\
\text { Easings }\end{array}$ & $\begin{array}{c}\text { Outflow } \\
\text { Easings }\end{array}$ & $\begin{array}{c}\text { Inflow } \\
\text { Tightenings }\end{array}$ & $\begin{array}{c}\text { Outflow } \\
\text { Tightenings }\end{array}$ & $\begin{array}{c}\text { Easings (not } \\
\text { in/out } \\
\text { specific) }\end{array}$ & $\begin{array}{c}\text { Tightenings } \\
\text { (not in/out } \\
\text { specific) }\end{array}$ \\
\hline ARG & 14 & 36 & 17 & 24 & 7 & 5 \\
BRA & 23 & 7 & 22 & 0 & 2 & 2 \\
CHL & 8 & 18 & 0 & 0 & 0 & 0 \\
CHN & 35 & 21 & 16 & 5 & 11 & 0 \\
COL & 6 & 3 & 9 & 3 & 4 & 5 \\
CZE & 5 & 1 & 0 & 0 & 0 & 1 \\
EGY & 1 & 1 & 0 & 0 & 1 & 0 \\
HUN & 5 & 6 & 2 & 0 & 4 & 5 \\
IDN & 2 & 1 & 5 & 3 & 2 & 5 \\
IND & 160 & 53 & 26 & 5 & 5 & 2 \\
KOR & 10 & 23 & 3 & 2 & 9 & 10 \\
MAR & 5 & 10 & 0 & 0 & 2 & 0 \\
MEX & 6 & 1 & 0 & 0 & 1 & 0 \\
MYS & 29 & 33 & 0 & 0 & 19 & 1 \\
PER & 20 & 20 & 20 & 1 & 9 & 24 \\
PHL & 6 & 26 & 2 & 2 & 10 & 2 \\
POL & 8 & 7 & 1 & 0 & 1 & 3 \\
RUS & 14 & 5 & 8 & 1 & 2 & 0 \\
THA & 16 & 30 & 14 & 0 & 2 & 1 \\
TUR & 6 & 11 & 2 & 0 & 7 & 16 \\
ZAF & 7 & 50 & 0 & 1 & 4 & 0 \\
\hline Total & 386 & 363 & 147 & 47 & 102 & 82 \\
\hline THE & 16 & 26 & 0 & 2 & 5 \\
\hline
\end{tabular}

Note: The table reports unweighted totals, for all actions i.e., including FDI-related changes. 


\section{APPENDIX C: DATA SOURCES AND DESCRIPTIONS}

Table C.1: Data Sources

\begin{tabular}{|c|c|c|}
\hline Series & Description & Source \\
\hline $\begin{array}{l}\text { Bank Credit-To-GDP } \\
(\%)\end{array}$ & $\begin{array}{l}\text { Bank credit to the private non-financial sector } \\
\text { (market value, end of quarter, adjusted for breaks, } \\
\% \text { of GDP). }\end{array}$ & $\begin{array}{l}\text { BIS; National } \\
\text { Sources; and } \\
\text { author's } \\
\text { calculations }\end{array}$ \\
\hline $\begin{array}{l}\text { Bank Credit-To-GDP } \\
\text { Gap (\%) }\end{array}$ & $\begin{array}{l}\text { Deviation of Bank Credit-to-GDP (\%) from its } \\
\text { backward-looking HP-filtered trend (lambda= } \\
25000) \text {. Bank credit to GDP gap is computed at } \\
\text { quarterly frequency and then interpolated to } \\
\text { weekly frequency. }\end{array}$ & $\begin{array}{l}\text { Author's } \\
\text { calculations }\end{array}$ \\
\hline CPI Inflation (yoy \%) & $\begin{array}{l}\text { Year-over-year log difference of seasonally } \\
\text { adjusted CPI (2010-100). CPI data is available at } \\
\text { quarterly frequency and is first seasonally } \\
\text { adjusted using Census X12 method in E-views, } \\
\text { and then linearly interpolated to weekly frequency, } \\
\text { before computing inflation rates over the previous } \\
52 \text { weeks. }\end{array}$ & $\begin{array}{l}\text { BIS and IMF } \\
\text { IFS }\end{array}$ \\
\hline Equity Prices & $\begin{array}{l}\text { Weekly average of main stock market index, } 23 \\
\text { Jun } 2004=100 \text {. Year over year percentage } \\
\text { change and deviation from } 10 \text {-year trend } \\
\text { calculated as for Spot exchange rate against } \\
\text { USD. }\end{array}$ & $\begin{array}{l}\text { Haver (Daily } \\
\text { database) }\end{array}$ \\
\hline $\begin{array}{l}\text { Exchange Market } \\
\text { Pressure }\end{array}$ & $\begin{array}{l}\text { Sum of normalized percentage nominal } \\
\text { appreciation against USD and normalized } \\
\text { percentage increase in reserves (both measured } \\
\text { over the previous } 13 \text { weeks). Both exchange rate } \\
\text { appreciation and growth in reserves are } \\
\text { normalized using their country-specific mean and } \\
\text { standard deviations. Growth in reserves is } \\
\text { calculated as the change in reserves from IMF } \\
\text { BOPS financial account detail, and divided by the } \\
\text { one-week lagged outstanding total reserves } \\
\text { (excluding gold) from IMF IIP. Both change in } \\
\text { reserves and reserves series are linearly } \\
\text { interpolated from quarterly data. }\end{array}$ & $\begin{array}{l}\text { IMF BOPS and } \\
\text { IIP via Haver, } \\
\text { and Datastream }\end{array}$ \\
\hline $\begin{array}{l}\text { Export Growth (yoy, } \\
\%)\end{array}$ & $\begin{array}{l}\text { Year over year growth, \%, Merchandise Exports, } \\
\text { Billions USD. }\end{array}$ & IMF DOTS \\
\hline $\begin{array}{l}\text { Export Volume Growth } \\
\text { (yoy, \%) }\end{array}$ & $\begin{array}{l}\text { Year over year growth, } \% \text {, Merchandise export } \\
\text { volume index }(2000=100) \text {. Growth rates } \\
\text { calculated from interpolated values. }\end{array}$ & UNCTAD \\
\hline
\end{tabular}


Table C.1: Data Sources

\begin{tabular}{|c|c|c|}
\hline Series & Description & Source \\
\hline $\begin{array}{l}\text { External Credit to GDP } \\
(\%)\end{array}$ & $\begin{array}{l}\text { Total external credit raised by domestic sectors } \\
\text { via foreign banks and issuance of international } \\
\text { debt securities, divided by nominal GDP in USD. } \\
\text { Sum of total cross-border loans from BIS reporting } \\
\text { banks in USD (all sectors, all currencies, creditor } \\
\text { reporting) from BIS locational banking statistics } \\
\text { and the amounts outstanding of international debt } \\
\text { securities (all maturities, all sectors, market } \\
\text { reported, nominal value) in USD from BIS } \\
\text { International Debt Securities Statistics. Both the } \\
\text { debt and GDP are interpolated to weekly values } \\
\text { before computing their ratio. Year over year } \\
\text { growth rates and deviation from 10-year trend as } \\
\text { computed for Spot exchange rate against USD. }\end{array}$ & BIS \\
\hline $\begin{array}{l}\text { External Credit to GDP } \\
\text { Gap (\%) }\end{array}$ & $\begin{array}{l}\text { External credit gap is the deviation of External } \\
\text { Credit to GDP (\%) from its lagged } 10 \text {-year moving } \\
\text { average. }\end{array}$ & $\begin{array}{l}\text { Author's } \\
\text { calculations }\end{array}$ \\
\hline $\begin{array}{l}\text { External Credit to } \\
\text { GDP, Non-Banks }(\%)\end{array}$ & $\begin{array}{l}\text { Same as External Credit to GDP (\%), but for } \\
\text { credit to non-banks sectors. }\end{array}$ & $\mathrm{BIS}$ \\
\hline $\begin{array}{l}\text { External Debt } \\
\text { Securities Net Flow (\% } \\
\text { of GDP) }\end{array}$ & $\begin{array}{l}\text { Net flows of international debt securities (all } \\
\text { maturities, issuers and currencies, market } \\
\text { reported, nominal value) in USD. Linear } \\
\text { interpolation to weekly from quarterly data. Then } \\
\text { divided by nominal GDP in USD. }\end{array}$ & $\begin{array}{l}\text { BIS } \\
\text { International } \\
\text { Debt Securities } \\
\text { Statistics }\end{array}$ \\
\hline $\begin{array}{l}\text { Federal Funds } \\
\text { Shadow Rate }\end{array}$ & $\begin{array}{l}\text { United States: Federal Funds Shadow Short Rate } \\
\text { Point Estimates (average, \% p.a.). }\end{array}$ & Haver \\
\hline Fiscal Stance & $\begin{array}{l}\text { Takes the value }+1 \text { if the change in structural } \\
\text { balance is positive, }-1 \text { for a decline in structural } \\
\text { balance and } 0 \text { otherwise. The general government } \\
\text { structural balance (\% of GDP) is from IMF WEO } \\
\text { and is linearly interpolated from annual data. }\end{array}$ & $\begin{array}{l}\text { IMF World } \\
\text { Economic } \\
\text { Outlook }\end{array}$ \\
\hline $\begin{array}{l}\text { Foreign Currency Debt } \\
\text { Securities Stock (\% of } \\
\text { GDP) }\end{array}$ & $\begin{array}{l}\text { Amounts outstanding of foreign currency } \\
\text { international debt securities (all maturities and } \\
\text { issuers, market reported, nominal value) in USD. } \\
\text { Linear interpolation to weekly from quarterly data. } \\
\text { Then divided by nominal GDP in USD. Deviation } \\
\text { from } 10 \text {-year trend computed as for nominal spot } \\
\text { exchange rate against USD. }\end{array}$ & $\begin{array}{l}\text { BIS } \\
\text { International } \\
\text { Debt Securities } \\
\text { Statistics }\end{array}$ \\
\hline $\begin{array}{l}\text { Foreign Currency Debt } \\
\text { Securities, Net Flows } \\
(\% \text { of GDP) }\end{array}$ & $\begin{array}{l}\text { Net flows of foreign currency international debt } \\
\text { securities (all maturities and issuers, market } \\
\text { reported, nominal value) in USD. Linear } \\
\text { interpolation to weekly from quarterly data. Then } \\
\text { divided by nominal GDP in USD. }\end{array}$ & $\begin{array}{l}\text { BIS } \\
\text { International } \\
\text { Debt Securities } \\
\text { Statistics }\end{array}$ \\
\hline
\end{tabular}


Table C.1: Data Sources

\begin{tabular}{|c|c|c|}
\hline Series & Description & Source \\
\hline $\begin{array}{l}\text { Growth of Residential } \\
\text { Property Prices (YoY, } \\
\%)\end{array}$ & $\begin{array}{l}\text { 52-week log difference, expressed as percentage, } \\
\text { of Residential Property Prices (Nominal, } \\
2010=100 \text { ). The RPP index is interpolated from } \\
\text { quarterly values. }\end{array}$ & BIS \\
\hline $\begin{array}{l}\text { Manufacturing IIP } \\
\text { Growth (yoy, \%) }\end{array}$ & $\begin{array}{l}\text { Year over year growth in seasonally adjusted } \\
\text { Index of Industrial Production (IIP) for } \\
\text { manufacturing sector (ISIC D). For China, total IP } \\
\text { excluding construction (ISIC C+D+E) is used. } \\
\text { Monthly IIP values interpolated to weekly before } \\
\text { computing 52-week growth rates. }\end{array}$ & BIS \\
\hline Measures in Force & $\begin{array}{l}\text { Number of Anti-dumping duties, Countervailing } \\
\text { duties, Safeguard measures or Quantitative } \\
\text { Restrictions on merchandise trade coming into } \\
\text { force in the given week. }\end{array}$ & $\begin{array}{l}\text { WTO-ITIP } \\
\text { goods }\end{array}$ \\
\hline Measures Initiated & $\begin{array}{l}\text { Number of Anti-dumping duties, Countervailing } \\
\text { duties, Safeguard measures or Quantitative } \\
\text { Restrictions on merchandise trade initiated in the } \\
\text { given week. }\end{array}$ & $\begin{array}{l}\text { WTO-ITIP } \\
\text { goods }\end{array}$ \\
\hline Measures Withdrawn & $\begin{array}{l}\text { Number of Anti-dumping duties, Countervailing } \\
\text { duties, Safeguard measures or Quantitative } \\
\text { Restrictions on merchandise trade withdrawn in } \\
\text { the given week. }\end{array}$ & $\begin{array}{l}\text { WTO-ITIP } \\
\text { goods }\end{array}$ \\
\hline $\begin{array}{l}\text { Monetary Policy } \\
\text { Stance }\end{array}$ & $\begin{array}{l}\text { Takes the value }+1 \text { if the change in the policy rate } \\
\text { is positive, }-1 \text { for a decline in policy rate and } 0 \\
\text { otherwise. Policy rates are official policy rates, } \\
\text { spliced with interbank rates if needed to } \\
\text { backward-extend the series (full details available } \\
\text { on request). }\end{array}$ & BIS \\
\hline & $\begin{array}{l}\text { Net inflows are computed as the net incurrence of } \\
\text { liabilities less let acquisition of foreign assets for } \\
\text { the following four categories: Foreign direct }\end{array}$ & \\
\hline $\begin{array}{l}\text { Net Capital Inflows (\% } \\
\text { of GDP) }\end{array}$ & $\begin{array}{l}\text { investment, portfolio investment, other investment } \\
\text { and financial derivatives, of the balance of } \\
\text { payments financial account. Interpolated to } \\
\text { weekly and then divided by weekly GDP, and } \\
\text { expressed as a percentage. }\end{array}$ & $\begin{array}{l}\text { IMF BOPS via } \\
\text { Haver }\end{array}$ \\
\hline Net Initiations & Measures Initiated - Measures Withdrawn & $\begin{array}{l}\text { WTO-ITIP } \\
\text { goods }\end{array}$ \\
\hline $\begin{array}{l}\text { Nominal Effective } \\
\text { Exchange Rate } \\
\text { (NEER) }\end{array}$ & $\begin{array}{l}\text { Nominal Broad Effective Exchange Rate } \\
\text { (Average, } 2010=100 \text { ). Weekly data linearly } \\
\text { interpolated from monthly. Changes and } \\
\text { deviations from trend computed as for Spot } \\
\text { exchange rate against USD. }\end{array}$ & BIS via Haver \\
\hline
\end{tabular}


Table C.1: Data Sources

\begin{tabular}{|c|c|c|}
\hline Series & Description & Source \\
\hline Nominal GDP in USD & $\begin{array}{l}\text { Nominal gross domestic product at current prices } \\
\text { \& exchange rates (Seasonally adjusted by Haver, } \\
\text { Haver codes: } \mathrm{H}^{* \star *} \text { NGCD@EMERGE). Quarterly } \\
\text { values linearly interpolated to weekly. }\end{array}$ & $\begin{array}{l}\text { National } \\
\text { Sources via } \\
\text { Haver }\end{array}$ \\
\hline $\begin{array}{l}\text { Other Investment } \\
\text { Inflows (Trend Dev.) }\end{array}$ & $\begin{array}{l}\text { Deviation from 10-year backward-looking moving } \\
\text { average of financial account, other investment } \\
\text { inflows (liabilities) expressed as percentage of } \\
\text { nominal GDP in USD. Other investment inflows } \\
\text { were seasonally adjusted using Census X12 } \\
\text { method in E-views. }\end{array}$ & IMF BOPS \\
\hline Previous Policy Action & $\begin{array}{l}\text { An indicator variable that takes the value }+1 \text { if the } \\
\text { last available policy action was a tightening and }-1 \\
\text { if the previous policy action was an easing. Policy } \\
\text { actions refer to net inflow tightening actions or net } \\
\text { NKI restricting actions, depending on the } \\
\text { specification. }\end{array}$ & $\begin{array}{l}\text { Author's } \\
\text { calculations }\end{array}$ \\
\hline $\begin{array}{l}\text { Real Effective } \\
\text { Exchange Rate } \\
\text { (REER) }\end{array}$ & $\begin{array}{l}\text { JP Morgan Broad Effective Exchange Rate Index, } \\
\text { PPI based, } 2010=100 \text { (Haver codes: } \\
X^{* \star * P P H @ I N T D A I L Y) . ~ W e e k l y ~ a v e r a g e s ~ o f ~ d a i l y ~} \\
\text { data. Changes and deviations from trend } \\
\text { computed as for Spot exchange rate against USD. }\end{array}$ & $\begin{array}{l}\text { JP Morgan, via } \\
\text { Haver }\end{array}$ \\
\hline $\begin{array}{l}\text { Relative GDP Growth } \\
\text { (yoy, \%) }\end{array}$ & $\begin{array}{l}\text { Real GDP growth in the EME less world real GDP } \\
\text { growth. Real GDP growth is (in general) yoy } \\
\text { growth in seasonally adjusted real GDP in } \\
\text { national currency from Haver, and world real GDP } \\
\text { growth from IMF WEO. Quarterly growth rates are } \\
\text { linearly interpolated. }\end{array}$ & $\begin{array}{l}\text { Haver and IMF } \\
\text { WEO }\end{array}$ \\
\hline $\begin{array}{l}\text { Relative Manufacturing } \\
\text { IIP Growth }\end{array}$ & $\begin{array}{l}\text { Manufacturing IIP growth in the relevant country } \\
\text { (computed as above), less average manufacturing } \\
\text { growth in all other EMEs in sample. }\end{array}$ & BIS \\
\hline $\begin{array}{l}\text { Spot Exchange Rate } \\
\text { against USD }\end{array}$ & $\begin{array}{l}\text { Weekly average of daily nominal spot exchange } \\
\text { rate against U.S. dollar, expressed in local } \\
\text { currency units (LCU) per dollar. Year-over-year } \\
\text { (yoy) changes computed as log difference over } \\
\text { previous } 52 \text { weeks. Quarter-over-quarter (qoq) } \\
\text { changes computed as log difference over } \\
\text { previous } 13 \text { weeks. Changes expressed as } \\
\text { percentage points. Also computed are deviations } \\
\text { of the current exchange rate from } 3 \text { - and } 5 \text { - and } \\
10 \text {-year ( } 156,260 \text { and } 520 \text { weeks respectively) } \\
\text { backward-looking moving averages. [For } 10 \text {-year } \\
\text { trends, if the past } 10 \text {-year data was not available } \\
\text { to compute the trend, the trend was computed } \\
\text { with as much data as available, as long as at least } \\
5 \text { years of past data was available. Otherwise, the } \\
\text { first } 5 \text { years of non-missing data was used to }\end{array}$ & $\begin{array}{l}\text { Thompson } \\
\text { Reuters } \\
\text { Datastream }\end{array}$ \\
\hline
\end{tabular}




\section{Table C.1: Data Sources}

\begin{tabular}{lll}
\hline Series & Description & Source \\
\hline & $\begin{array}{l}\text { compute the trend, in which case the trend is both } \\
\text { backward- and forward-looking for the first five } \\
\text { years of observations.] }\end{array}$ & \\
\hline $\begin{array}{l}\text { Total Credit-To-GDP } \\
\text { Gap (\%) }\end{array}$ & $\begin{array}{l}\text { BIS Total Credit to GDP gap. Interpolated to } \\
\text { weekly from quarterly data. }\end{array}$ & BIS \\
\hline
\end{tabular}


Table C2: Summary Statistics

\begin{tabular}{|c|c|c|c|c|c|c|c|c|c|c|c|}
\hline & \multicolumn{6}{|c|}{ Original Variables } & \multicolumn{5}{|c|}{ Standard Deviation Units } \\
\hline & $\mathrm{N}$ & Min & Max & Mean & Median & S.D. & Min & Max & Mean & Median & S.D. \\
\hline $\begin{array}{l}\text { Weighted Net Inflow } \\
\text { Tightenings (non-FDI) }\end{array}$ & 16380 & -3.1 & 1.7 & 0.0 & 0.0 & 0.1 & & & & & \\
\hline $\begin{array}{l}\text { Weighted Net NKI } \\
\text { Restrictions (non-FDI) }\end{array}$ & 16380 & -2.4 & 1.7 & 0.0 & 0.0 & 0.1 & & & & & \\
\hline Measures Inforce & 16380 & 0.0 & 63.0 & 4.4 & 0.0 & 11.9 & & & & & \\
\hline Measures Initiated & 16380 & 0.0 & 60.0 & 0.2 & 0.0 & 1.1 & & & & & \\
\hline Measures Withdrawn & 16380 & 0.0 & 18.0 & 0.1 & 0.0 & 0.6 & & & & & \\
\hline Net Initiations & 16380 & -18.0 & 60.0 & 0.1 & 0.0 & 1.2 & & & & & \\
\hline \multicolumn{12}{|l|}{ Mercantilist Motivations } \\
\hline $\begin{array}{l}\text { Exchange market } \\
\text { pressure }\end{array}$ & 15710 & -8.0 & 5.1 & 0.2 & 0.2 & 1.3 & -5.0 & 3.6 & 0.1 & 0.2 & 1.0 \\
\hline Export Growth (yoy, \%) & 16380 & -72.2 & 72.4 & 8.5 & 10.5 & 18.7 & -3.3 & 3.1 & 0.5 & 0.6 & 1.0 \\
\hline $\begin{array}{l}\text { Export Volume Growth } \\
\text { (yoy, \%) }\end{array}$ & 9166 & -77.7 & 61.5 & 6.2 & 6.2 & 12.4 & -3.8 & 5.9 & 0.7 & 0.8 & 1.0 \\
\hline $\begin{array}{l}\text { Manufacturing IIP Growth } \\
\text { (yoy \%) }\end{array}$ & 14812 & -25.3 & 35.9 & 4.2 & 4.3 & 7.5 & -3.5 & 4.9 & 0.7 & 0.7 & 1.2 \\
\hline $\begin{array}{l}\text { Mercantilism Proxy } \\
\text { (Nominal, 13-wk appr., } \\
\%)\end{array}$ & 16380 & -462.7 & 167.2 & -0.4 & 2.1 & 39.5 & -5.4 & 4.1 & 0.1 & 0.1 & 1.0 \\
\hline $\begin{array}{l}\text { Mercantilism Proxy } \\
\text { (Nominal, yoy appr., \%) }\end{array}$ & 16380 & -190.7 & 95.5 & -0.4 & 2.1 & 21.6 & -4.1 & 3.5 & 0.1 & 0.1 & 1.1 \\
\hline $\begin{array}{l}\text { Mercantilism Proxy (Real, } \\
\text { 13-wk appr., \%) }\end{array}$ & 16380 & -466.6 & 192.5 & -0.9 & 0.6 & 40.0 & -5.2 & 3.7 & 0.0 & 0.0 & 1.0 \\
\hline $\begin{array}{l}\text { Mercantilism Proxy (Real, } \\
\text { yoy appr., \%) }\end{array}$ & 16380 & -167.3 & 97.4 & -0.9 & -0.2 & 20.3 & -3.6 & 3.4 & 0.0 & 0.0 & 1.0 \\
\hline NEER (13-wk growth, \%) & 14820 & -61.0 & 18.4 & -0.5 & 0.0 & 5.2 & -6.2 & 3.5 & -0.1 & 0.0 & 1.0 \\
\hline $\begin{array}{l}\text { NEER (Deviation from 3- } \\
\text { year trend) }\end{array}$ & 14820 & -104.6 & 24.3 & -3.5 & -1.3 & 12.5 & -4.5 & 2.9 & -0.2 & -0.2 & 1.1 \\
\hline $\begin{array}{l}\text { NEER (Deviation from 5- } \\
\text { year trend) }\end{array}$ & 14820 & -132.5 & 28.0 & -6.4 & -2.7 & 17.8 & -4.7 & 3.0 & -0.3 & -0.3 & 1.2 \\
\hline NEER (yoy growth, \%) & 14820 & -71.8 & 34.5 & -1.7 & -0.9 & 10.4 & -4.0 & 3.3 & -0.1 & -0.1 & 1.0 \\
\hline $\begin{array}{l}\text { Net Capital Inflows/GDP } \\
\text { (Deviation from 10-yr } \\
\text { Trend) }\end{array}$ & 15732 & -16.2 & 10.8 & -0.1 & 0.0 & 3.3 & -3.2 & 3.6 & 0.0 & 0.0 & 1.1 \\
\hline $\begin{array}{l}\text { Relative GDP Growth } \\
\text { (yoy, \%) }\end{array}$ & 16380 & -13.6 & 11.6 & 0.4 & 0.4 & 3.1 & -4.2 & 6.3 & 0.2 & 0.2 & 1.3 \\
\hline $\begin{array}{l}\text { Relative Manufacturing } \\
\text { IIP Growth }\end{array}$ & 14812 & -20.4 & 32.4 & 0.0 & -0.2 & 6.0 & -3.5 & 5.2 & 0.0 & 0.0 & 1.2 \\
\hline $\begin{array}{l}\text { Spot Exchange Rate } \\
\text { (Deviation from 3-year } \\
\text { trend) }\end{array}$ & 16369 & -113.2 & 78.9 & -2.2 & 0.0 & 15.0 & -4.3 & 5.1 & -0.1 & 0.0 & 1.1 \\
\hline $\begin{array}{l}\text { Spot Exchange Rate } \\
\text { (Deviation from 5-year } \\
\text { trend) }\end{array}$ & 16369 & -146.8 & 150.6 & -3.7 & -0.1 & 23.3 & -4.1 & 3.8 & -0.1 & 0.0 & 1.1 \\
\hline $\begin{array}{l}\text { Spot Exchange Rate } \\
\text { against U.S. dollar (13-wk } \\
\text { growth, \%) }\end{array}$ & 16358 & -52.4 & 21.4 & -0.2 & 0.1 & 5.8 & -6.2 & 5.6 & 0.0 & 0.0 & 1.0 \\
\hline
\end{tabular}


58

\begin{tabular}{|c|c|c|c|c|c|c|c|c|c|c|c|}
\hline & \multicolumn{6}{|c|}{ Original Variables } & \multicolumn{5}{|c|}{ Standard Deviation Units } \\
\hline & $\mathrm{N}$ & Min & Max & Mean & Median & S.D. & Min & Max & Mean & Median & S.D. \\
\hline $\begin{array}{l}\text { Spot Exchange Rate } \\
\text { against U.S. dollar (yoy } \\
\text { growth, \%) }\end{array}$ & 16365 & -72.7 & 45.8 & -0.8 & 0.0 & 12.5 & -3.8 & 3.6 & 0.0 & 0.0 & 1.0 \\
\hline $\begin{array}{l}\text { Macroprudential } \\
\text { Motivations }\end{array}$ & & & & & & & & & & & \\
\hline $\begin{array}{l}\text { Bank Credit to Private } \\
\text { non-Financial Sector (\% } \\
\text { of GDP), qoq change }\end{array}$ & 14820 & -6.5 & 10.5 & 0.3 & 0.3 & 1.2 & -4.8 & 4.5 & 0.3 & 0.3 & 1.0 \\
\hline $\begin{array}{l}\text { Bank Credit to Private } \\
\text { non-Financial Sector ( } \% \\
\text { of GDP), yoy change }\end{array}$ & 14820 & -21.6 & 22.7 & 1.1 & 1.2 & 3.9 & -3.4 & 3.9 & 0.4 & 0.5 & 1.1 \\
\hline $\begin{array}{l}\text { Bank Credit to Private } \\
\text { non-Financial Sector (qoq } \\
\% \text { growth) }\end{array}$ & 14820 & -12.8 & 17.6 & 3.3 & 3.1 & 3.2 & -3.9 & 5.6 & 1.4 & 1.3 & 1.1 \\
\hline $\begin{array}{l}\text { Bank Credit to Private } \\
\text { non-Financial Sector (yoy } \\
\% \text { growth) }\end{array}$ & 14820 & -25.2 & 67.2 & 14.5 & 13.3 & 12.4 & -2.1 & 5.5 & 1.8 & 1.7 & 1.3 \\
\hline $\begin{array}{l}\text { Bank Credit-to-GDP gap } \\
(\%)\end{array}$ & 14820 & -23.5 & 16.9 & 1.3 & 1.9 & 5.4 & -2.6 & 4.0 & 0.4 & 0.6 & 1.1 \\
\hline $\begin{array}{l}\text { Equity Prices (yoy } \\
\text { growth, \%) }\end{array}$ & 15955 & -133.0 & 137.6 & 9.4 & 9.2 & 29.8 & -3.1 & 3.4 & 0.4 & 0.4 & 1.0 \\
\hline $\begin{array}{l}\text { Equity Prices, (23 Jun } \\
\text { 2004=100) Trend } \\
\text { Deviation }\end{array}$ & 16090 & -187.9 & 849.8 & 79.5 & 56.0 & 105.2 & -1.3 & 4.4 & 1.0 & 0.8 & 1.1 \\
\hline $\begin{array}{l}\text { External Credit (\% of } \\
\text { GDP) }\end{array}$ & 16342 & 2.5 & 119.6 & 18.8 & 16.4 & 11.5 & 0.3 & 8.6 & 3.9 & 3.8 & 1.6 \\
\hline $\begin{array}{l}\text { External Credit (\% of } \\
\text { GDP), Trend Deviation }\end{array}$ & 16342 & -31.0 & 68.2 & -0.6 & -0.1 & 8.3 & -2.6 & 3.7 & 0.0 & 0.0 & 1.2 \\
\hline $\begin{array}{l}\text { External Credit (\% of } \\
\text { GDP), yoy change }\end{array}$ & 16290 & -39.8 & 75.3 & 0.0 & 0.1 & 5.4 & -3.1 & 3.6 & 0.1 & 0.0 & 1.0 \\
\hline $\begin{array}{l}\text { External Credit by non- } \\
\text { Banks ( } \% \text { of GDP) }\end{array}$ & 16342 & 0.9 & 108.3 & 13.6 & 11.3 & 10.5 & 0.3 & 9.4 & 3.8 & 3.7 & 1.7 \\
\hline $\begin{array}{l}\text { External Credit by non- } \\
\text { Banks ( } \% \text { of GDP), yoy } \\
\text { change }\end{array}$ & 16290 & -34.0 & 68.8 & 0.0 & 0.0 & 4.7 & -2.7 & 3.6 & 0.0 & 0.0 & 1.0 \\
\hline $\begin{array}{l}\text { External Debt Securities } \\
\text { Net Flow ( } \% \text { of GDP) }\end{array}$ & 16342 & -43.5 & 9.2 & 0.8 & 0.6 & 2.2 & -6.6 & 4.8 & 0.6 & 0.4 & 1.0 \\
\hline $\begin{array}{l}\text { External Debt Securities } \\
\text { Stock (\% of GDP) }\end{array}$ & 16342 & 0.3 & 90.1 & 10.5 & 9.1 & 8.9 & 0.2 & 9.7 & 3.4 & 3.4 & 1.8 \\
\hline $\begin{array}{l}\text { External Debt Securities } \\
\text { Stock (\% of GDP), yoy } \\
\text { change }\end{array}$ & 16290 & -26.5 & 58.4 & 0.3 & 0.1 & 3.9 & -2.9 & 3.6 & 0.2 & 0.1 & 1.0 \\
\hline $\begin{array}{l}\text { Foreign Currency Ext. } \\
\text { Debt Securities Net Flow } \\
\text { (\% of GDP) }\end{array}$ & 16342 & -43.3 & 9.2 & 0.7 & 0.5 & 2.1 & -6.6 & 4.9 & 0.5 & 0.4 & 1.0 \\
\hline $\begin{array}{l}\text { Foreign Currency Ext. } \\
\text { Debt Securities Stock (\% } \\
\text { of GDP) }\end{array}$ & 16342 & 0.3 & 89.5 & 9.9 & 8.2 & 8.8 & 0.2 & 9.0 & 3.3 & 3.3 & 1.7 \\
\hline $\begin{array}{l}\text { Foreign Currency Ext. } \\
\text { Debt Securities Stock (\% } \\
\text { of GDP), yoy change }\end{array}$ & 16290 & -26.3 & 58.5 & 0.2 & 0.1 & 3.9 & -2.9 & 3.6 & 0.2 & 0.1 & 1.0 \\
\hline
\end{tabular}

CInternational Monetary Fund. Not for Redistribution 


\begin{tabular}{|l|c|c|c|c|c|c|c|c|c|c|c|}
\hline & \multicolumn{9}{|c|}{ Original Variables } & \multicolumn{3}{c|}{ Standard Deviation Units } \\
\hline & $\mathrm{N}$ & Min & Max & Mean & Median & S.D. & Min & Max & Mean & Median & S.D. \\
\hline $\begin{array}{l}\text { Foreign Currency Ext. } \\
\text { Debt Securities Stock (\% } \\
\text { of GDP, Trend Deviation) }\end{array}$ & 16342 & -24.0 & 53.1 & 0.5 & 0.3 & 5.7 & -2.4 & 3.8 & 0.4 & 0.2 & 1.2 \\
\hline $\begin{array}{l}\text { REER (Deviation from 3- } \\
\text { year trend) }\end{array}$ & 16380 & -49.0 & 35.3 & 0.5 & 0.5 & 7.5 & -3.8 & 3.2 & 0.1 & 0.1 & 1.0 \\
\hline $\begin{array}{l}\text { REER (Deviation from 5- } \\
\text { year trend) }\end{array}$ & 16380 & -57.5 & 33.7 & 1.3 & 1.3 & 10.2 & -4.2 & 3.4 & 0.2 & 0.2 & 1.1 \\
\hline REER (qoq growth, \%) & 16380 & -40.1 & 28.1 & 0.2 & 0.2 & 4.6 & -5.5 & 4.3 & 0.0 & 0.1 & 1.0 \\
\hline REER (yoy growth, \%) & 16380 & -48.1 & 34.9 & 0.7 & 0.6 & 8.5 & -3.5 & 3.4 & 0.1 & 0.1 & 1.0 \\
\hline $\begin{array}{l}\text { Residential Property } \\
\text { Prices (yoy growth, \%) }\end{array}$ & 10362 & -24.1 & 49.5 & 6.6 & 5.3 & 8.1 & -2.5 & 7.2 & 1.5 & 1.3 & 1.5 \\
\hline $\begin{array}{l}\text { Short Term Ext. Debt } \\
\text { Securities Net Flow (\% of } \\
\text { GDP) }\end{array}$ & 14820 & -1.8 & 2.5 & 0.0 & 0.0 & 0.2 & -5.8 & 5.9 & 0.1 & 0.0 & 0.9 \\
\hline $\begin{array}{l}\text { Total Credit-to-GDP Gap } \\
\text { (\%) }\end{array}$ & 11847 & -51.0 & 39.9 & -0.1 & 2.2 & 13.3 & -2.4 & 3.8 & 0.3 & 0.3 & 1.3 \\
\hline
\end{tabular}


Table C3: Top 5 Trade Competitors of Emerging Markets in Sample in 2012

\begin{tabular}{|l|l|l|l|l|l|}
\hline $\begin{array}{l}\text { Countries in } \\
\text { Sample }\end{array}$ & \multicolumn{5}{|c|}{ Trade Competitors in 2012 } \\
\hline Argentina & $\begin{array}{l}\text { New } \\
\text { Zealand }\end{array}$ & Uruguay & Australia & Brazil & Chile \\
\hline Brazil & Argentina & Uruguay & $\begin{array}{l}\text { New } \\
\text { Zealand }\end{array}$ & South Africa & Australia \\
\hline Chile & Peru & South Africa & $\begin{array}{l}\text { New } \\
\text { Zealand }\end{array}$ & Armenia & Georgia \\
\hline China & Turkey & Vietnam & India & Tunisia & Italy \\
\hline Colombia & Kenya & Egypt & Zimbabwe & Peru & Nigeria \\
\hline $\begin{array}{l}\text { Czech } \\
\text { Republic }\end{array}$ & Hungary & Slovakia & Romania & Estonia & Poland \\
\hline Egypt & Tunisia & Turkey & Colombia & Saudi Arabia & Algeria \\
\hline Hungary & $\begin{array}{l}\text { Czech } \\
\text { Republic }\end{array}$ & Romania & Bulgaria & Thailand & Slovakia \\
\hline India & Pakistan & China & Turkey & Vietnam & Thailand \\
\hline Indonesia & Vietnam & Malaysia & Peru & Kenya & Philippines \\
\hline $\begin{array}{l}\text { Korea, } \\
\text { Republic of }\end{array}$ & Taiwan & Japan & Germany & Italy & Spain \\
\hline Malaysia & Indonesia & Thailand & Nigeria & Pakistan & Viet Nam \\
\hline Mexico & Poland & Turkey & Tunisia & Viet Nam & Thailand \\
\hline Morocco & Tunisia & Macedonia & Albania & Kenya & Peru \\
\hline Peru & Chile & Morocco & Kenya & Zimbabwe & Indonesia \\
\hline Philippines & Kenya & Morocco & Tunisia & Vietnam & Indonesia \\
\hline Poland & Mexico & Lithuania & Turkey & $\begin{array}{l}\text { Czech } \\
\text { Republic }\end{array}$ & Serbia \\
\hline $\begin{array}{l}\text { Russian } \\
\text { Federation }\end{array}$ & Canada & United Arab \\
Emirates & Norway & Qatar & Algeria \\
\hline South Africa & Chile & Armenia & $\begin{array}{l}\text { New } \\
\text { Zealand }\end{array}$ & Australia & Zimbabwe \\
\hline Turkey & Pakistan & China & Portugal & Egypt & Tungey \\
\hline & & & & & \\
\hline
\end{tabular}

